\title{
ESTUDO AMBIENTAL PARA OS PROGRAMAS DE FOMENTO FLORESTAL DA ARACRUZ CELULOSE S. A. E EXTENSÃO FLORESTAL DO GOVERNO DO ESTADO DO ESPÍRITO SANTO
}

\section{1 - INTRODUÇÃO}

Joésio Deoclécio Pierin Siqueira ${ }^{1}$ Rômulo Sousa Lisboa ${ }^{2}$ Aguimar Mendes Ferreira ${ }^{3}$ Mara Freire Rodrigues de Souza ${ }^{4}$ Elmar de Araújo ${ }^{5}$ Luciano Lisbão Júnior ${ }^{6}$

Majoe de Meirelles Siqueira ${ }^{7}$

O Programa de Extensão Florestal do Estado do Espírito Santo foi criado pelo Governo do Estado, através do convênio SEAG / EMATER / ITCF, atual IDAF, tendo como objetivo, promover a ocupação das áreas marginais das pequenas e médias propriedades do Estado, com o apoio técnico da EMATER e da Aracruz Celulose S.A., que disponibilizou os insumos (mudas e iscas formicidas). O Programa é desenvolvido nos 78 municípios do Estado, resultando em uma área de influência de $46.184,1 \mathrm{~km}^{2}$. Até o ano de 1995, foram distribuídas seis milhões de mudas, com um total de 1.872 produtores beneficiados. O programa perdeu intensidade a partir de 1995, tendo sido interrompido temporariamente em 1998, após a invasão do Movimento Sem Terra no viveiro centralizador da distribuição, em Linhares.

A criação do Programa de Fomento Florestal, da Aracruz Celulose S.A., veio ao encontro da reivindicação do Governo Estadual de possibilitar a oferta de matéria-prima florestal por meio da participação de pequenos e médios produtores rurais em programas de reflorestamento do Estado, desconcentrando a área de formação de florestas e possibilitando a redução da pressão sobre as florestas naturais, pelo aproveitamento de subprodutos florestais para a transformação em lenha e carvão. O programa teve início em 1990 e, até 30 de junho de 2000, encontrava-se instalado em 49 municípios do Estado, perfazendo uma área de $32.426,4 \mathrm{~km}^{2}$ (70,2\% da área do Estado), com um plantio de 17.422,40 ha. Somente a Microrregião de ltapemirim, responsável por $1.279,1 \mathrm{~km}^{2}$, não foi contemplada pelo Programa de Fomento.

A sociedade civil organizada, as ONG's e os órgãos públicos (em seus mais diversos níveis e instâncias de decisão), vinham discutindo com freqüência as formas de implementação dos Programas de Fomento Florestal da Aracruz e de Extensão Florestal do Governo do Estado. No entanto, em 1992, representantes de ONG's deram origem a uma ação civil pública por danos ambientais causados pela implementação dos referidos programas. $\mathrm{Na}$ evolução do processo, foi formulado um acordo através de um Termo de Ajustamento de Conduta - TAC, junto ao Ministério Público, envolvendo as diversas partes, e que previa o compromisso de desenvolver um Estudo Ambiental para os Programas de Fomento Florestal da Aracruz e Extensão Florestal do Governo do Espírito Santo.

O presente documento, intitulado "Estudo Ambiental para os Programas de Fomento Florestal da Aracruz Celulose S. A. e Extensão Florestal do Governo do Estado do Espírito Santo" contempla a síntese dos estudos ambientais realizados pela STCP Engenharia de Projetos Ltda. para avaliar os impactos decorrentes da produção florestal no Estado do Espírito Santo.

\footnotetext{
${ }^{1}$ Engenheiro Florestal, Doutor em Política Florestal, professor adjunto da UFPR e Diretor da STCP Engenharia de Projetos Ltda. (executora do trabalho).

${ }^{2}$ Engenheiro Florestal, gerente de Unidade de Negócios da STCP Engenharia de Projetos Ltda.

${ }^{3}$ Engenheiro Florestal, Mestre em Economia e Política Florestal e gerente de Unidade de Negócios da STCP Engenharia de Projetos Ltda.

${ }^{4}$ Advogada e Engenheira Florestal, Mestre em Manejo Florestal e consultora da STCP Engenharia de Projetos Ltda.

${ }^{5}$ Engenheiro Florestal, consultor da STCP Engenharia de Projetos Ltda.

${ }_{7}^{6}$ Engenheiro Agrônomo, Doutor em Ciências Florestais e gerente de Meio Ambiente e Segurança Florestal da Aracruz Celulose S. A.

${ }^{7}$ Bióloga, Consultora da STCP Engenharia de Projetos Ltda.
} 


\section{2 - OBJETIVOS}

\section{1 - Geral}

Avaliar os impactos ambientais do Programa de Fomento Florestal da Aracruz Celulose S. A. e do Programa de extensão Florestal do Estado do Espírito Santo.

\section{2 - Específicos}

- Propor medidas mitigadoras para os impactos negativos e medidas potencializadoras dos impactos positivos com a implementação dos referidos programas;

- Definir e estruturar um programa de monitoramento das atividades relacionadas ao Programa de Fomento; e,

- Apresentar um Estudo da potencialidade, restrições ambientais e recomendações de uso sustentável das diferentes regiões bioclimáticas do Estado, indicando as espécies florestais mais adequadas para o plantio e fazer recomendações quanto ao uso das mesmas.

\section{3 - METODOLOGIA DO ESTUDO}

A metodologia adotada para o desenvolvimento do Estudo foi orientada para atender ao exposto no Termo de Ajustamento de Conduta (TAC), firmado entre a Procuradoria Geral da República, Aracruz Celulose, IBAMA e Governo do Estado do Espírito Santo.

Para o diagnóstico ambiental foram desenvolvidas as seguintes atividades:

- Revisão bibliográfica;

- Coleta de informações em instituições públicas e privadas do Espírito Santo;

- Contato e entrevista com técnicos, pesquisadores, especialistas nas áreas de conhecimento de interesse do estudo, ONG's, Igrejas, etc.;

- Levantamento de campo junto aos produtores rurais envolvidos com 0 programa de fomento da Aracruz; e,

- Elaboração do documento de diagnóstico.

Adicionalmente foi realizada a avaliação dos impactos ambientais do Programa de Fomento, através da Matriz de Leopold, adaptada para a situação local, e também a descrição destes impactos, para os quais estão associadas medidas compensatórias, mitigadoras ou minimizadoras destes impactos.

Paralelamente são apresentados os programas ambientais a serem desenvolvidos pelo empreendedor, a fim de acompanhar a evolução da qualidade ambiental, permitindo a adoção de medidas de controle para todas as fases do Programa de fomento.

\section{4 - ASPECTOS GERAIS}

\section{1 - Histórico de Ocupação do Estado}

O Estado do Espírito Santo constituiu-se numa longa faixa no litoral brasileiro, e é conhecido como a Terra do "Nilo Brasiliense", em referência ao Delta do Rio Nilo, no Egito, devido à presença do Rio Doce, entidade hidrográfica de grande importância na colonização capixaba.

Servindo de ligação entre o Atlântico e os sertões das Minas Gerais, o Estado do Espírito Santo possui uma história repleta de fatos relevantes como invasões, corrida por metais preciosos, ciclo do açúcar e do café e outros que ilustram a evolução histórica deste Estado.

A história do Espírito Santo começa junto com a de outras Capitanias do Brasil. Situada no litoral, a Capitania foi doada por D. João III ao nobre Vasco Fernandes Coutinho, que aportou à sua Capitania em 23 de maio de 1535. A princípio, o Rio e a primeira vila receberam o nome de Espírito Santo, por ser um domingo de Pentecostes. Posteriormente, esse nome foi estendido a toda a Capitania.

$\mathrm{Na}$ ocupação da capitania, foi priorizada a região costeira, por sua acessibilidade, tendo sido desenvolvida a exploração da cana-deaçúcar com base na mão-de-obra indígena. Entretanto, os índios eram extremamente hostis e os conflitos com os colonos resultaram em várias mortes de ambos os lados. Os colonos que sobreviviam acabavam fugindo para Capitanias vizinhas e, a conseqüência disso, foi o abandono da Vila do Espírito Santo, que passou a se chamar Vila Velha.

Em 1550 os colonos se refugiaram em um novo local. Travou-se então nova luta entre portugueses e índios, desta vez vencida pelos primeiros. Os colonizadores passaram a crer que essa grande vitória foi fruto da intervenção da Virgem Maria, consagrando-lhe então a 
fundação da nova vila, que foi denominada Vila de Nossa Senhora da Vitória. Porém, a tranqüilidade que tanto ansiavam os colonizadores só chegou com os jesuítas, que catequizaram os índios e pacificaram a região. Posteriormente a Vila de Nossa Senhora da Vitória foi convertida na capital do Estado, passando a ser denominada somente por Vitória.

Durante um longo período, a Capitania do Espírito Santo sofreu com várias tentativas de invasão. Frente a estes ataques ao seu litoral, o governo português destacou para a Capitania uma tropa regular. Foi através da militarização da região que o desenvolvimento econômico chegou ao Espírito Santo, destacandose o cultivo da cana-de-açúcar.

A busca pelo ouro e pedras preciosas também foi um fator de ocupação e desenvolvimento da Capitania pois, para viabilizar as expedições, foi necessário aumentar o contingente da população branca na Capitania, já que o grupo existente não era suficiente. Foi também por meio das expedições para a busca do ouro, que se iniciou a conquista e ocupação do interior, onde foram estabelecidos vilas, fortes, povoações e engenhos.

A partir do século XVIII, o desenvolvimento do comércio de exportação e da indústria intensificou-se na Capitania. Essa situação resultou em um aumento considerável da população, que passou de 7.773 habitantes em 1773 / 74 para 15.000 habitantes em 1780, ou seja, praticamente dobrou.

Durante o movimento de independência do país, no século XIX, ocorreram várias comoções políticas no território capixaba. Com a proclamação da autonomia brasileira, a Capitania do Espírito Santo passou, em 1822, à condição de província. Nessa situação, desenvolveu-se como um dos territórios mais favoráveis do Novo Reino, começando, a partir desse momento, a participar de um modo mais expressivo da história brasileira.

No século XIX a Província do Espírito Santo cresceu economicamente com o café e a imigração, ilustrando a importância da sua participação na fase de transição da economia brasileira, uma vez que neste período as elites elaboraram as leis de substituição da mão-deobra escrava pela imigrante e o uso de terras devolutas. A colonização da região do Rio Doce ficou inserida neste sistema, onde o cultivo e o uso da terra eram a garantia da propriedade.

Com a proclamação da República, em 1889, a província passou à condição de Estado. $\mathrm{O}$ desenvolvimento vivido nessa fase se materializou no próprio saneamento da cidade de Vitória, em 1895. Outro ponto destacável nesse período foi a inauguração do primeiro trecho da Estrada de Ferro Sul do Espírito Santo, entre Porto de Argolas e Jabaeté.

Durante a República, o Estado Capixaba conheceu grande desenvolvimento econômico e social. Com a Revolução de 1930 e a desvalorização do café, o Espírito Santo entrou em decadência, o que também aconteceu com a maioria dos estados produtores de café.

Diante desses fatos, os pequenos proprietários buscaram novas culturas como alternativa econômica, entre as quais se destacaram o milho, a banana, a mandioca, o feijão, o arroz e o cacau. A pecuária também cresceu após os anos 30, passando a ocupar os solos virgens no norte do estado, principalmente após a construção da ponte sobre o Rio Doce, no final da década de 20.

Outro ponto que se destacou na formação do Estado Moderno foi a presença da indústria de papel e celulose, quando o reflorestamento de Eucalyptus ganhou espaço no quadro econômico capixaba. As instalações do Porto de Tubarão e da Companhia Vale do Rio Doce também foram grandes marcos para a formação do atual Estado do Espírito Santo.

Desse modo, o Espírito Santo, próspero Estado do presente, ajudou a construir o desenvolvimento socioeconômico do Brasil, pois a colonização da área de influência do Rio Doce e a imigração estrangeira para o Estado Capixaba, fizeram parte de um período de transição da própria história brasileira, caracterizada pela evolução da ocupação do solo, desde o período colonial até o considerado Espírito Santo Moderno.

\section{2 - Estrutura Fundiária}

A estrutura fundiária do Estado do Espírito Santo caracteriza-se por uma forte predominância de pequenas propriedades (área inferior a 100 ha) que representam $44,03 \%$ da área total do Estado, sendo que os imóveis com área inferior a 100 ha representam $91,28 \%$ do total cadastrado no censo agropecuário de 
1996 (figura 1). Os restantes 55,97\% da área total de 3,488 milhões de ha estão distribuídos nos grupos restantes, que representam somente $8,72 \%$ dos estabelecimentos, ou seja, um percentual reduzido de proprietários detém a maioria das terras do Estado, principalmente os classificados no grupo de estabelecimentos entre 100 e 1000 ha, com 40,53\% da área, representando em torno de 1,4 milhões de ha.

\section{3 - Uso e Ocupação Atual do Solo}

No que diz respeito à situação atual de uso e ocupação do solo, as informações levantadas nos Censos realizados nos anos de 1975, 1985 e 1995 (quadro 1 e figura 2), demonstram que:

- A área ocupada com pastagens no Estado é a que apresenta maior representatividade em relação ao total, mas reduziu cerca de 310 mil ha entre os anos de 1975 e 1995;

- A agricultura permanente apresentou um acréscimo de mais de 100\% em área ocupada no Estado, entre os anos de 1975 e 1985, provavelmente devido ao incentivo dado nesse período à cultura cafeeira. A partir de 1985, apresentando redução em área plantada;
- Em relação às áreas ocupadas por agricultura temporária, estas apresentaram um ligeiro acréscimo entre os anos de 1975 e 1985, em torno de $11 \%$. Mas a partir desse ano até o ano de 1995, sofreu uma redução drástica de aproximadamente 162 mil ha (45\%), ocupando atualmente cerca de 193 mil ha;

- As áreas ocupadas com florestas naturais sofreram uma redução drástica ao longo dos anos e atualmente ocupam somente 8,1\% do Estado, sendo 2,7\% representado por unidades de conservação. Essa redução, como em todo o país, é influenciada por vários fatores, principalmente os antrópicos, tanto que no período entre 1975 e 1995 , sua área reduziu em torno de $68 \mathrm{mil} \mathrm{ha,}$ ou seja, $0,2 \%$ em relação ao total de área do Estado do Espírito Santo;

- A área ocupada por florestas plantadas aumentou cerca de $76 \%$ em relação à plantada em 1975 e tem se mantido estável nos últimos anos;

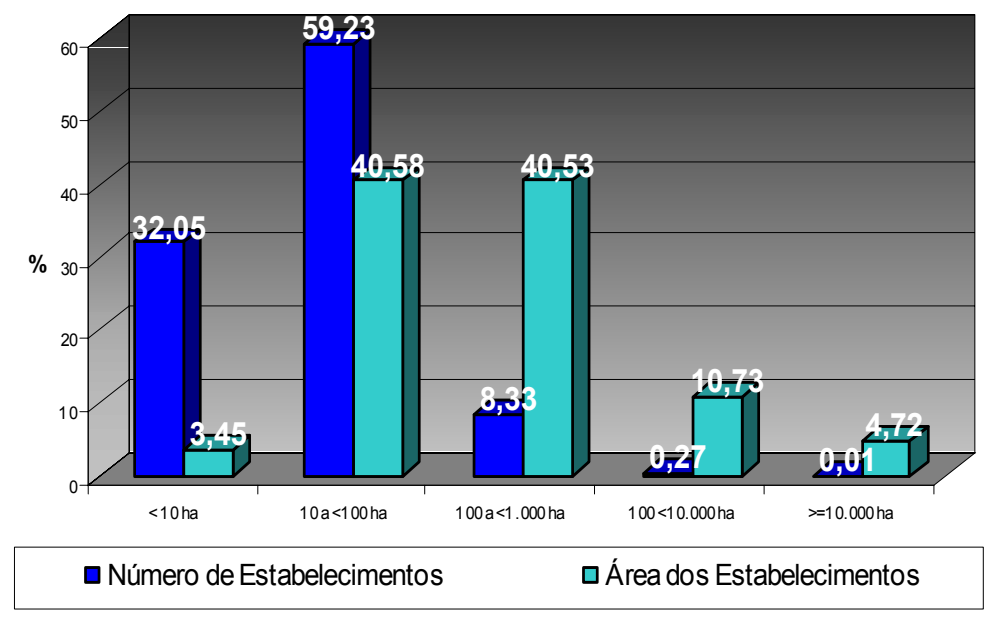

Figura 1: Estrutura Fundiária do Estado do Espírito Santo

Fonte: IBGE - Censo Agropecuário 1995-1996

- As áreas produtivas sem uso reduziram de 358 mil ha em 1975, para 145 mil em 1995. Boa parte destas foram ocupadas com plantio de espécies florestais, através dos programas de extensão do Estado ou programas de fomento de empresas privadas; e,
- No relativo às áreas improdutivas, percebe-se que ocorreu uma pequena redução, mas conclusões precisas só poderão ser formadas quando se obtiverem mais informações. 
Estudo ambiental para os programas de fomento...

Quadro 1: Uso e Ocupação do Solo no Estado do Espírito Santo

\begin{tabular}{|l|c|c|}
\hline \multicolumn{1}{|c|}{ ÍTEM } & ÁREA (ha) & \% $^{(\mathbf{1})}$ \\
\hline \hline Floresta Natural & 371.862 & 8,1 \\
- Florestas & 247.121 & 5,4 \\
- Unidades de Conservação & 124.741 & 2,7 \\
\hline Floresta Plantada & 173.934 & 3,8 \\
\hline Agricultura Temporária & 193.445 & 4,2 \\
\hline Agricultura Permanente & 635.077 & 13,8 \\
\hline Pastagem & 1.821 .069 & 39,4 \\
- Natural & 762.638 & 16,5 \\
- Plantada & 1.058 .431 & 22.9 \\
\hline Áreas Produtivas Não Utilizadas & 144.838 & 3,1 \\
\hline Áreas Improdutivas & 149.703 & 3,2 \\
\hline Outros & 1.128 .482 & 24,4 \\
\hline TOTAL & $\mathbf{4 . 6 1 8 . 4 1 0}$ & $\mathbf{1 0 0 , 0}$ \\
\hline \hline
\end{tabular}

(1) Em relação à área total do Estado do Espírito Santo

Fonte: Censo Agropecuário - IBGE 1995/96

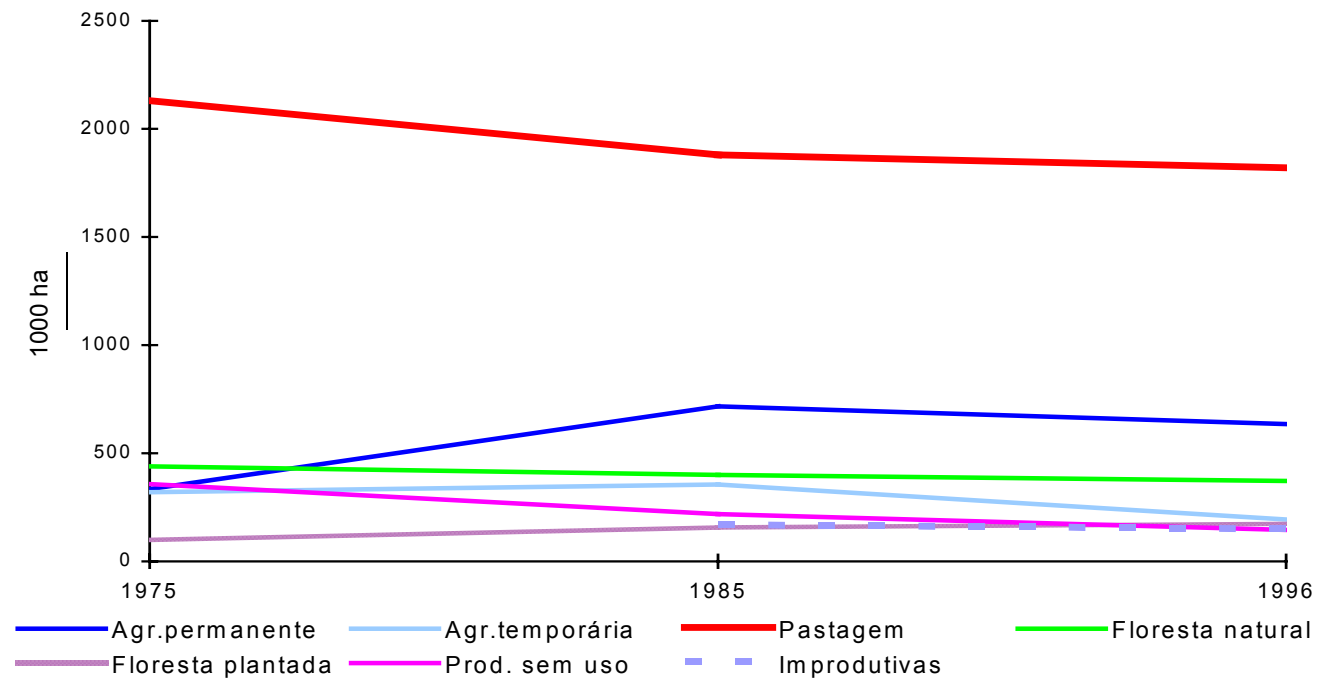

Figura 2: Evolução do Uso e Ocupação do Solo no Estado do Espírito Santo

Fonte: Censo Agropecuário - IBGE (1975, 1985 e 1995)

\section{5 - EVOLUÇÃO DAS ATIVIDADES FLORESTAIS}

\section{1 - História}

A madeira era utilizada no Espírito Santo desde o início da colonização, porém somente a partir de 1938, com a conquista da região norte do Estado, é que a madeira passou a ocupar posição de destaque na economia capixaba. Dois fatores contribuíram para a efetivação da atividade madeireira da região norte do Estado: a construção da ponte sobre o rio Doce em Colatina, permitindo o acesso rodoviário às florestas da região e a construção da ferrovia ligando Colatina a São Mateus, que gerou forte demanda por dormentes.

A exploração de florestas naturais no Espírito Santo teve um caráter predatório e entrou em declínio no final da década de 1960 e início da década de 1970, com o esgotamento das reservas florestais nativas e com o aumento do custo de transporte de madeira proveniente de áreas mais distantes. 
Entre 1967 e 1986, o Governo Federal implantou o Programa de Incentivos Fiscais ao Reflorestamento que, no Espírito Santo, promoveu a ocupação de extensas áreas com plantios homogêneos, principalmente Eucalyptus e Pinus, mudando o enfoque da exploração florestal de áreas naturais para plantadas, alterando também o perfil industrial, de madeireiro para celulose, através da implantação de importante pólo de celulose nos cenários regional e nacional. Como conseqüência, entre 1975 e 1995, a área reflorestada no Espírito Santo praticamente dobrou, com um crescimento médio anual na ordem de 2,9\%. Após 1995, a área ocupada com reflorestamentos no Estado tem-se mantido praticamente constante.

\section{2 - Área Plantada}

Analisando a evolução da área plantada no Estado, é possível perceber que entre os anos de 1971 e 1977, período em que os incentivos fiscais do Governo Federal eram vigentes, essa área cresceu de forma considerável (quadro 2).
A partir de 1985, observa-se um crescimento da área plantada até o ano de 1995 e, a partir daí, praticamente se estabilizando. Esse crescimento deve-se principalmente aos plantios próprios executados pelas empresas privadas, visando seu consumo de madeira futuro, uma vez que estudos de mercado vêm evidenciando a tendência de falta de madeira no mercado nacional. Esse crescimento também foi influenciado pelos Programas de Extensão Florestal do Governo Estadual e pelos Programas de Fomento Florestal de iniciativa das empresas privadas, principalmente da Aracruz Celulose S.A.

$\mathrm{Na}$ área de influência do Programa de Fomento Florestal da Aracruz S. A. (figura 3), a área plantada compreende 168.589 ha (IBGE, 1995/96), correspondendo a 97,1\% da área plantada do Estado. No mesmo local, o Programa de Fomento implantou, até junho de $2000,17.422,40$ ha, o que representa $10 \%$ da área plantada no Estado, conforme censo agropecuário realizado pelo IBGE entre os anos de 1995 e 1996.

Quadro 2: Evolução das Áreas Plantadas no Estado do Espírito Santo (ha)

\begin{tabular}{|c|c|c|c|c|c|}
\hline \hline \multirow{2}{*}{ ANO } & \multirow{2}{*}{ EUCALIPTO } & \multirow{2}{*}{ PINUS } & \multirow{2}{*}{ OUTROS } & \multicolumn{2}{|c|}{ TOTAL } \\
\cline { 4 - 6 } & & & & ANUAL & ACUMULADO \\
\hline \hline $1967 / 68^{(2)}$ & 3.183 & 34 & 36 & 3.253 & 3.253 \\
\hline $1969^{(2)}$ & 5.324 & 25 & 48 & 5.397 & 8.650 \\
\hline $1970^{(2)}$ & 4.996 & 41 & 26 & 5.063 & 13.713 \\
\hline $1971^{(2)}$ & 9.005 & 73 & 164 & 9.242 & 22.955 \\
\hline $1972^{(2)}$ & 17.125 & 189 & 298 & 17.612 & 40.567 \\
\hline $1973^{(2)}$ & 13.515 & 190 & 226 & 13.931 & 54.498 \\
\hline $1974^{(2)}$ & 12.999 & 161 & 122 & 13.282 & 67.780 \\
\hline $1975^{(2)}$ & 21.458 & 216 & 188 & 21.862 & 89.642 \\
\hline $1976^{(2)}$ & 16.291 & 4 & 167 & 16.462 & 106.104 \\
\hline $1977^{(2)}$ & 15.480 & 45 & 152 & 15.677 & 121.781 \\
\hline $1978^{(2)}$ & 4.526 & - & 26 & 4.500 & 126.281 \\
\hline $1979^{(2)}$ & 3.404 & 12 & 80 & 3.496 & 129.777 \\
\hline $1980^{(2)}$ & 1.529 & - & - & 1.529 & 131.306 \\
\hline $1981^{(2)}$ & 458 & - & - & 458 & 131.764 \\
\hline $1985^{(3)}$ & - & - & - & 98.368 & 98.368 \\
\hline $1990^{(4)}$ & 140.865 & 4.797 & 3.868 & 149.530 & 149.530 \\
\hline $1995^{(3)}$ & - & - & - & 172.735 & 172.735 \\
\hline $1998^{(5)}$ & 170.037 & 3.897 & - & 173.934 & 173.934 \\
\hline \hline
\end{tabular}

(1) Considera plantios de Citrus, Palmito e outras nativas; ${ }^{(2)}$ Fonte: Política de Reflorestamento no Espírito Santo, IBDF/1982; ${ }^{(3)}$ Fonte: Censo Agropecuário 1985 e 1995; ${ }^{(4)}$ Fonte: Antônio C. Prado, março/1995; ${ }^{(5)}$ Fonte: STCP, Aracruz e Outras empresas do Estado do Espírito Santo, base somente plantios de Eucalyptus e Pinus. 
Estudo ambiental para os programas de fomento...

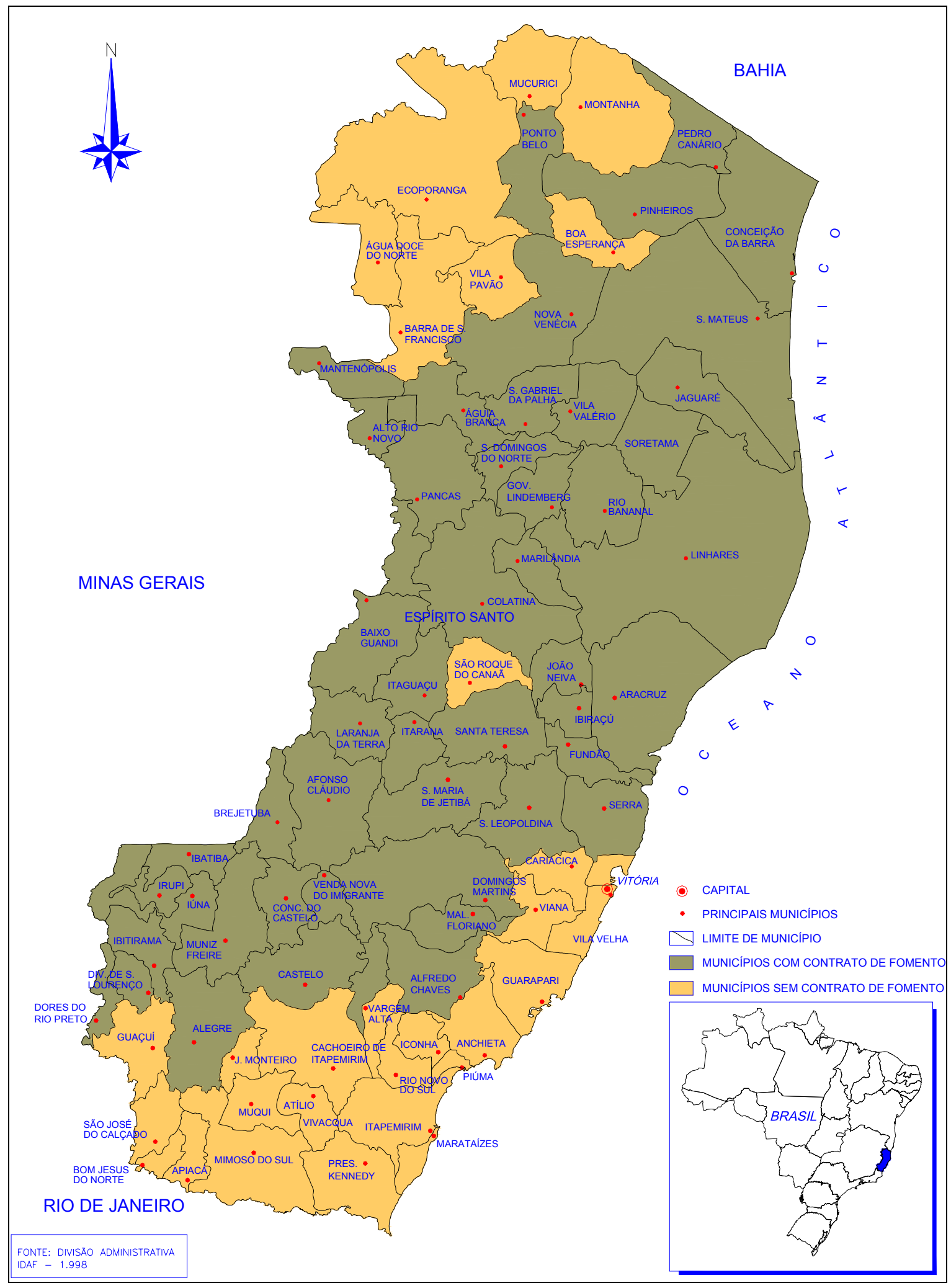

Figura 3: Distribuição dos municípios sob influência do programa de fomento 


\section{3 - Aspectos Técnicos dos Plantios Florestais}

\section{- Estado do Espírito Santo}

- Espécies aptas: a espécie que melhor se adaptou em termos de uniformidade de desenvolvimento e incremento foi $o$ Eucalyptus grandis, procedente da Rodésia e África do Sul. Mas, devido a sua susceptibilidade ao Cryphonectria cubensis, foi necessário que novas espécies fossem estudadas. A partir de 1978 , as sementes mais plantadas foram de Eucalyptus urophylla, procedente de Camaquã, sendo esta mais resistente ao Cryphonectria cubensis, mas com uniformidade e produtividade menores que o Eucalyptus grandis. Entretanto, os avanços tecnológicos alcançados pela pioneira Aracruz Florestal S.A. e a possibilidade de produção de híbridos e clones de matrizes com fenótipos superiores em escala, revolucionaram o setor, aumentando as possibilidades de produção madeireira (acima de 60 $\mathrm{m}^{3} / \mathrm{ha} / \mathrm{ano}$ ) e, ao mesmo tempo, utilizando indivíduos mais resistentes às pragas e intempéries da região.

- Implantação e manutenção: essas atividades sofreram grandes transformações tecnológicas para atender a demanda do mercado, passando de processos manuais para sistemas altamente mecanizados. No Espírito Santo, cerca de $85 \%$ dos reflorestamentos pertencem às empresas vinculadas à indústria florestal de alta produção, podendo-se afirmar que o Estado é um dos que apresenta destaque na utilização de novas tecnologias na implantação de florestas com exóticas no País.

- Colheita florestal: os sistemas mais atuais variam de acordo com a estratégia adotada, onde o processamento é realizado com harvester (derrubada, desgalhamento e traçamento); $\mathrm{o}$ carregamento e transporte até o estaleiro com forwarder; carregamento dos caminhões com gruas florestais $\mathrm{e}$ transporte em treminhões, entre outros. Porém, essa tecnologia não é aplicável para todos os fins florestais, pois depende da topografia, declividade dos terrenos, distância de extração, espécie plantada, tipo de solo, rendimento da floresta, finalidade do produto explorado, disponibilidade de mão-de-obra especializada, capacidade de investimento, entre outros, sendo que, nesses casos, é necessário recorrer a determinadas técnicas não-mecanizadas.

\section{- Área de influência do Programa de Fomento}

Como o Programa de Fomento Florestal da Aracruz abrange praticamente $98 \%$ das áreas onde estão localizados os reflorestamentos no Estado do Espírito Santo, os aspectos técnicos, supracitados, aplicam-se integralmente a sua área de influência.

Entretanto, em alguns estabelecimentos participantes do programa (pequenas propriedades), apesar da assistência técnica fornecida pela Aracruz, o ciclo de produção é pouco desenvolvido tecnologicamente e a mãode-obra utilizada é, em sua maioria, familiar, sendo que os equipamentos utilizados são os mesmos aplicados em outras atividades da propriedade, com algumas adaptações. A especificidade só ocorre na colheita, onde a derrubada, desgalhamento e traçamento são realizados com motosserra e o baldeio através do tombamento até a beira da estrada em terrenos muito inclinados, ou baldeio manual com caminhão dentro do carreador em propriedades com menor inclinação. Somente o descarregamento no depósito de madeira da Aracruz é realizado com carregadores florestais.

\section{4 - Aspectos Econômicos}

\subsection{1 - Estado do Espírito Santo}

\section{- Florestas Nativas}

Uma floresta nativa remanescente é considerada econômica quando está estrategicamente localizada e disponível para utilização, após serem considerados os aspectos de preservação, lazer e recreação. Dessa forma, apenas uma parte da cobertura florestal nativa remanescente no Estado do Espírito Santo é "produtiva". Essa área em 1982, era de aproximadamente $27 \mathrm{mil}$ ha (KISE, 1984) e, face aos volumes de produção verificados nas duas últimas 
décadas (figura 4), é fácil concluir que os estoques disponíveis no Estado não oferecem potencial econômico sustentável, em especial porque a exploração ainda prossegue em moldes primitivos, tradicionais e ligados à abertura/ limpeza de áreas de agricultura. (BRASIL, 1995).

\section{- Florestas Plantadas}

Para as florestas plantadas, a situação é diferenciada daquela constatada para as florestas nativas. O Estado possui cerca de $35 \%$ de sua área com aptidão preferencial para a atividade florestal, apresentando os maiores índices mundiais de produtividade de Eucalyptus, associados a uma posição geográfica privilegiada e uma boa estrutura viária (figura 5). Nesse contexto, a produção florestal constitui-se numa excelente opção de diversificação da propriedade rural, gerando renda alternativa aos produtores, novos empregos (quadro 3), recuperação e conservação do solo e da água, reduzindo a freqüência, intensidade e secas pedológicas, além do aproveitamento de áreas marginais.

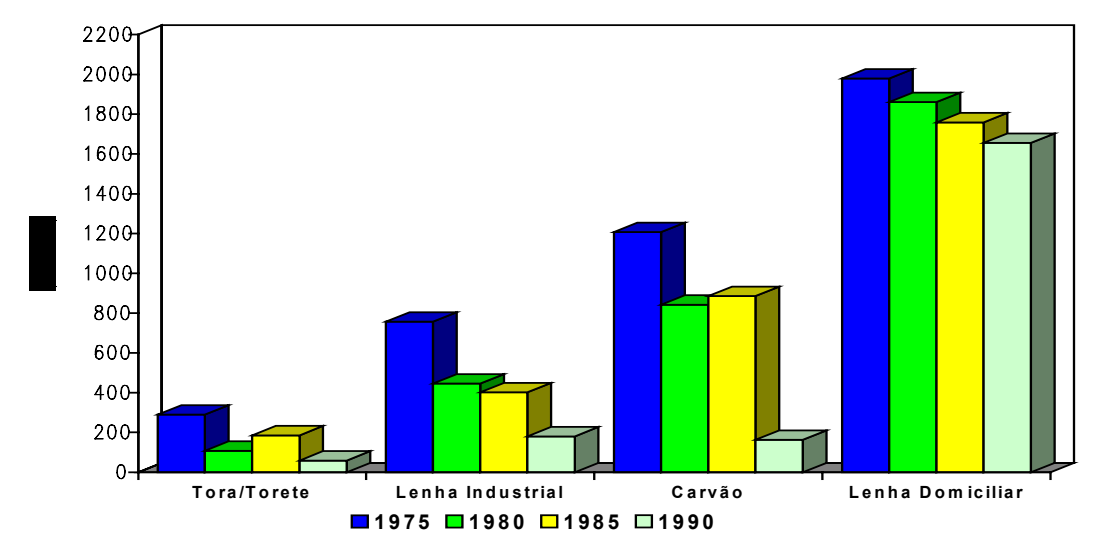

Figura 4: Evolução da Produção de Madeira Roliça de Matas Nativas para Uso Industrial e Domiciliar no Estado

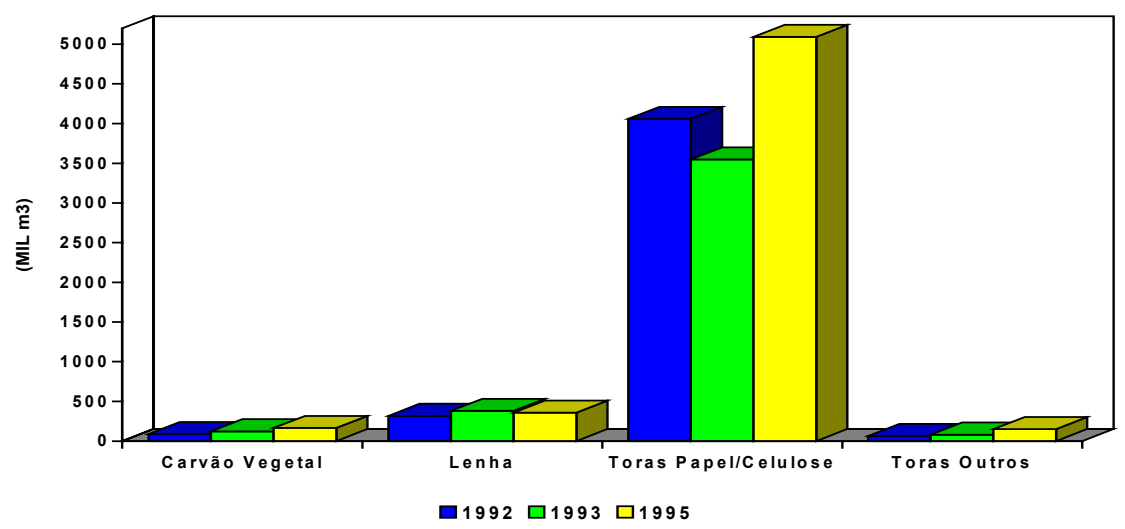

Figura 5: Evolução da Produção de Madeira de Florestas Plantadas no Estado Fonte: ESPÍRITO SANTO (1998). IBGE $(1992,1995)$.

Quadro 3: Estimativa da Geração de Empregos no Setor Florestal do Estado (1988)

\begin{tabular}{|l|c|}
\hline \hline \multicolumn{1}{|c|}{ SEGMENTO } & N $^{\mathbf{0}}$ DE EMPREGOS CRIADOS \\
\hline \hline Madeireiro & 6.686 \\
\hline Reflorestamento & 663 \\
\hline Celulose & 7.138 \\
\hline Carvoejamento: Florestas Nativas & 2.044 \\
Reflorestamento & 323 \\
\hline \hline \multicolumn{1}{|c|}{ TOTAL } & $\mathbf{1 6 . 8 5 4}$ \\
\hline \hline
\end{tabular}

Fonte: ESPÍRITO SANTO (1988) 
Segundo SALVADOR (1992), a oferta de matéria-prima florestal no Estado não satisfaz a demanda energética de celulose; de escoramento na construção civil e de caixotaria para embalagens de produtos agrícolas, sendo recomendada a implantação de mais 181.560 ha nos anos seguintes a 1992, para alcançar o equilíbrio entre a oferta e a demanda. Entretanto, nesse quadro de déficit, é importante mencionar que a área total necessária para atender essa demanda até 2013 (315.806 ha), é cerca de cinco vezes menor que a área com aptidão exclusiva $e$ preferencial para silvicultura no Estado.

$\mathrm{O}$ setor florestal teve um papel representativo na distribuição populacional do Estado, principalmente pelo segmento de celulose, tanto que no ano de 1987, o número de mão-de-obra empregada por esse segmento superou o da indústria madeireira. $\mathrm{O}$ mesmo segmento movimentou US\$ $147.574 .010 \mathrm{em}$ vendas, no ano de 1985, o que correspondeu a $56,7 \%$ do total do setor agrícola. Quanto aos impostos, em 1985 o segmento de celulose contribuiu com US\$7.634.121, equivalendo a $2,9 \%$ do total de impostos gerados pelo setor agrícola.

No que se refere aos investimentos no setor, as florestas implantadas entre 1967 e 1987 representaram investimentos de US\$ 75,7 milhões com os incentivos fiscais, tendo-se como base os valores atribuídos pelo IBDF para a implantação e manutenção de plantios, durante os três primeiros anos (ESPÍRITO SANTO, 1988). Somente a Aracruz, considerada uma das maiores empresas do setor de base florestal no Brasil, realizou investimentos na ordem de US\$ 54 milhões na implantação de uma nova empresa para produção de madeira serrada destinada à indústria moveleira e à construção civil - a Tecflor Industrial S.A. (GAZETA
MERCANTIL, 1997), indústria essa inaugurada em 1999.

\subsection{2 - Área de Influência do Programa de Fomento}

\section{- Florestas Nativas}

No que diz respeito às florestas nativas, é possível perceber que, para todos os produtos de extração vegetal, houve redução da quantidade total produzida entre 1992 e 1995 . A produção de carvão vegetal proveniente de florestas nativas na área de influência do Programa de Fomento correspondia, em 1995, a 99,9\% da produção no Estado do Espírito Santo. A produção de lenha e de madeira em toras, nesse mesmo ano, também é bastante expressiva na área de influência, correspondendo respectivamente a $82,6 \%$ e $85,9 \%$ da produção do Estado.

\section{- Florestas Plantadas}

Ao contrário do observado para a extração vegetal de florestas nativas, as florestas plantadas apresentaram crescimento na produção/consumo, no período de 1992 a 1995 (quadro 4). O maior crescimento da produção $(137,7 \%)$ foi observado para madeira em toras para outras finalidades, passando de $62.302 \mathrm{~m}^{3}$ em 1992 para $148.119 \mathrm{~m}^{3}$ em 1995.

No que se refere à geração de empregos, GRIGATO \& MORROT (1991), aportam que Programa possibilitará a oferta de emprego para aproximadamente 1.465 indivíduos, em média, na implantação da floresta e exploração da madeira. Os serviços de transportes também serão beneficiados com o programa, na medida em que os produtores necessitarem entregar a madeira nos depósitos de recolhimento da Aracruz.

Quadro 4: Produção de Florestas Plantadas no Espírito Santo e na Área de Influência do Programa de Fomento (1995)

\begin{tabular}{|c|c|c|c|}
\hline \multirow[t]{2}{*}{ PRODUTO } & \multirow{2}{*}{$\begin{array}{c}\text { PRODUÇÃO NO ESPÍRITO } \\
\text { SANTO }\left(\mathrm{m}^{3}\right)\end{array}$} & \multicolumn{2}{|c|}{$\begin{array}{l}\text { NA ÁREA DE INFLUÊNCIA DO } \\
\text { PROGRAMA DE FOMENTO }\end{array}$} \\
\hline & & PRODUÇÃO $\left(\mathrm{m}^{3}\right)$ & \% DO ESTADO \\
\hline Carvão Vegetal * & 165.683 & 158.697 & 95,8 \\
\hline Lenha & 357.720 & 338.761 & 94,7 \\
\hline $\begin{array}{l}\text { Madeira em Tora } \\
\text { Para Papel } \\
\text { Outras Finalidades }\end{array}$ & $\begin{array}{c}5.243 .351 \\
5.092 .808 \\
150.543 \\
\end{array}$ & $\begin{array}{c}5.240 .927 \\
5.092 .808 \\
148.119 \\
\end{array}$ & $\begin{array}{c}100,0 \\
100,0 \\
98,4 \\
\end{array}$ \\
\hline TOTAL & 5.766 .754 & 5.738 .385 & - \\
\hline
\end{tabular}

* Rendimento médio considerado do carvão $=230 \mathrm{~kg}$ de carvão para $1,0 \mathrm{~m}^{3}$ de madeira plantada. Fonte: IBGE (1995). 


\section{6 - DIAGNÓSTICO AMBIENTAL}

\section{1 - Meio Físico}

\subsection{1 - Clima}

Segundo a classificação de Köppen, o Espírito Santo enquadra-se nas zonas climáticas $\mathrm{A}$ e $\mathrm{C}$, sendo a primeira quente e úmida e a outra tropical de altitude (mesotérmico). O Estado compreende ainda os tipos climáticos $\mathrm{Aw}, \mathrm{Am}, \mathrm{Cf}$ e $\mathrm{Cw}$, e também as variações $\mathrm{Cfa}, \mathrm{Cfb}$, $\mathrm{Cwa}$ e $\mathrm{Cwb}$, sendo que o clima é influenciado, de maneira marcante, pelo relevo, altitude e exposição das serras.

A área com maior precipitação anual $(1.597$ a $2.184 \mathrm{~mm})$ e menor déficit hídrico (0 a $148 \mathrm{~mm}$ ) no Estado do Espírito Santo, compreende uma parte das Mesorregiões Central e Sul, incluindo a parte elevada dos Municípios de Domingos Martins, Marechal Floriano, Alfredo Chaves, Vargem Alta e Iconha. Esta área apresenta praticamente todos os meses do ano como chuvosos (precipitação igual ou maior que a evapotranspiração potencial).

A temperatura no Estado varia de acordo com a faixa de altitude, podendo ser classificada da seguinte forma:
- Altitude de 0 a $450 \mathrm{~m}$ - compreende a quase totalidade das Mesorregiões Litoral Norte e Nordeste (em $73 \%$ da área do Estado), apresenta temperatura média anual variando entre 21,3 a $24,4{ }^{\circ} \mathrm{C}$;

- $\quad$ Altitude de 450 a $850 \mathrm{~m}$ - se faz presente em quase todas as Mesorregiões do Estado (em 17\% da área do Estado), tendo temperaturas médias anuais variando entre 19,0 a $21,3{ }^{\circ} \mathrm{C}$;

- Altitude de 850 a $1.200 \mathrm{~m}$ - abrange parte das Mesorregiões Central e Sul ( $9 \%$ da área do Estado), apresentando temperatura média anual variando de 16,6 a $19,0{ }^{\circ} \mathrm{C}$;

- Altitude superior a $1.200 \mathrm{~m}$ - áreas dentro das Mesorregiões Central e Sul (1\% do Estado), apresentando temperatura média anual inferior a $16,6^{\circ} \mathrm{C}$.

No quadro 5 são apresentados os índices de Umidade Relativa do Ar por municípios.

No quadro 6 são apresentadas as informações relativas à classificação climática, precipitação e temperatura das Microrregiões existentes na área do Programa de Fomento.

Quadro 5: Umidade Relativa Média Mensal de Diferentes Localidades do Estado

\begin{tabular}{|c|c|c|c|c|c|c|}
\hline \hline \multirow{2}{*}{ MESES } & \multicolumn{7}{|c|}{ UMIDADE RELATIVA DO AR (\%) POR MUNICÍPIO } \\
\cline { 2 - 7 } & $\begin{array}{c}\text { Cachoeiro de } \\
\text { Itapemirim }\end{array}$ & Vitória & $\begin{array}{c}\text { Domingos } \\
\text { Martins }\end{array}$ & Linhares & $\begin{array}{c}\text { São Gabriel da } \\
\text { Palha }\end{array}$ & $\begin{array}{c}\text { Conceição da } \\
\text { Barra }\end{array}$ \\
\hline \hline Janeiro & 78 & 80 & 81 & 82 & 75 & 83 \\
\hline Fevereiro & 76 & 78 & 80 & 81 & 74 & 83 \\
\hline Março & 79 & 79 & 81 & 84 & 71 & 84 \\
\hline Abril & 81 & 79 & 84 & 84 & 76 & 84 \\
\hline Maio & 81 & 79 & 85 & 84 & 78 & 84 \\
\hline Junho & 81 & 80 & 84 & 85 & 78 & 86 \\
\hline Julho & 80 & 79 & 83 & 86 & 77 & 84 \\
\hline Agosto & 78 & 78 & 82 & 84 & 73 & 82 \\
\hline Setembro & 77 & 78 & 81 & 84 & 72 & 82 \\
\hline Outubro & 78 & 80 & 84 & 85 & 74 & 84 \\
\hline Novembro & 80 & 80 & 82 & 85 & 75 & 85 \\
\hline Dezembro & 80 & 80 & 83 & 84 & 75 & 85 \\
\hline \hline MÉDIA & $\mathbf{7 9}$ & $\mathbf{7 9}$ & $\mathbf{8 3}$ & $\mathbf{8 4}$ & $\mathbf{7 5}$ & $\mathbf{8 4}$ \\
\hline \hline
\end{tabular}

Fonte: EMCAPA (1986) 
Quadro 6: Informações Climáticas Gerais das Microrregiões Existentes na Área do Programa de Fomento

\begin{tabular}{|c|c|c|c|}
\hline \multirow{2}{*}{ MICRORREGIÃO } & CLIMA & PRECIPITAÇÃO & TEMPERATURA \\
\hline & $\begin{array}{c}\text { Tipos Predominantes } \\
\text { (Köppen) }\end{array}$ & $\begin{array}{l}\text { Variação Média } \\
\text { Anual (mm) }\end{array}$ & $\begin{array}{c}\text { Variação Média } \\
\text { Anual }\left({ }^{\circ} \mathbf{C}\right)\end{array}$ \\
\hline Barra de São Francisco & Aw, Cwa & 500 a 1.250 & 22 a 23 \\
\hline Nova Venécia & Aw & 750 a 1.250 & 23 \\
\hline Colatina & Aw, Cwa & 500 a 1.000 & 22 a 23 \\
\hline Montanha & Aw & 1.250 a 1.500 & 23 \\
\hline São Mateus & Aw, Am & 1.000 a 1.500 & 23 \\
\hline Linhares & Aw & 750 a 1.300 & 23 \\
\hline Afonso Cláudio & $\mathrm{Aw}, \mathrm{Cwa}, \mathrm{Cfa}, \mathrm{Cfb}$ & $1.000 \mathrm{a} 2.000$ & 20 a 22 \\
\hline Santa Teresa & Aw, Am, Cwa, Cfa & 750 a 2.000 & 20 a 23 \\
\hline Vitória & Am, Aw & $1.000 \mathrm{a} 1.700$ & 22 a 23 \\
\hline Guarapari & Am, Aw, Cfa & 1.000 a 1.500 & 20 a 23 \\
\hline Alegre & Cwb, Cwa & 1.000 a 1.250 & 19 a 23 \\
\hline Cachoeiro de Itapemirim & Aw, Cwa, Cwb & 1.000 a 1.500 & 21 a 23 \\
\hline
\end{tabular}

\subsection{2 - Relevo e Solos}

Tomando-se como base a Carta Agroclimática do Espírito Santo (EMCAPA, 1986), apresenta-se no quadro 7, a distribuição das áreas e os respectivos percentuais das diferentes classes de altitude no Estado do Espírito Santo. Da mesma forma que o relevo, a altitude da área de influência do Programa de Fomento e do Estado não apresentam diferenças significativas, sendo caracterizado nesse item apenas a altitude do Estado.

A topografia das terras do Espírito Santo é bastante variada, podendo ser encontradas desde áreas planas até escarpadas. A área do Espírito Santo com declividade inferior a 30\%, corresponde a 57,34\% do território do Estado, enquanto que as declividades situadas entre $30 \%$ e $100 \%$ representam $41,49 \%$, sendo o restante, $1,17 \%$, representado por declividades superiores a $100 \%$ (formadas em sua maior parte por solos Litólicos e Afloramentos de Rocha).
A área com declividade inferior a 30\%, na região de influência do Programa de Fomento, é de 1,9 milhões de ha, o que corresponde a $58,96 \%$ dessa área. A área com declividade entre 30 e $100 \%$, com 1,29 milhões de ha, representa $39,88 \%$ e a área com declividade acima de $100 \%$, com 37 mil ha representa $1,16 \%$.

O Estado do Espírito Santo é constituído fisicamente por três regiões distintas, segundo RADAMBRASIL (1983) e IBGE (1987), definidas por uma heterogenidade de fatores físicos atuantes e resultando em diferentes classes de solos para cada uma destas regiões, são elas (figura 6):

- Região Litorânea;

- Região de Tabuleiros; e,

- Região Elevada Interior.

Nos parágrafos seguintes são descritas as características pedológicas associadas a essas unidades.

Quadro 7: Distribuição das Classes de Altitude no Estado

\begin{tabular}{|c|c|c|}
\hline \hline CLASSE DE ALTITUDE & ÁREA $\mathbf{( k m}^{\mathbf{2}}$ & \% \\
\hline \hline 0 a $450 \mathrm{~m}$ & 33.760 & 73,10 \\
\hline 450 a $850 \mathrm{~m}$ & 7.939 & 17,19 \\
\hline 850 a $1.200 \mathrm{~m}$ & 4.046 & 8,76 \\
\hline$>1.200 \mathrm{~m}$ & 439 & 0,95 \\
\hline \hline TOTAL & $\mathbf{4 6 . 1 8 4}$ & $\mathbf{1 0 0 , 0 0}$ \\
\hline \hline
\end{tabular}

Fonte: EMCAPA (1986) 


\section{- Região Litorânea}

A região litorânea corresponde a $5 \%$ da área do Estado, caracterizada por apresentar relevo plano e solos arenosos (Areias Quartzosas) nas áreas com vegetação natural de restinga, além de solos indiscriminados de Mangue e solos Hidromórficos, na maioria orgânicos, com dificuldade de drenagem onde ocorre vegetação pantanosa.

Os solos arenosos são, em sua maior parte, ácidos e de baixa fertilidade, apresentando grande vulnerabilidade à degradação causada pela ação antrópica, através de métodos de manejo tradicionalmente utilizados, como a retirada da vegetação nativa, uso do fogo, mecanização, etc. Este tipo de manejo reduz drasticamente o teor da matéria orgânica, que é uma das poucas fontes de nutrientes nestes solos.

Os solos arenosos são encontrados em toda a costa litorânea do Estado, concentrandose na região norte. Os solos Hidromórficos concentram-se, especificamente nos vales da Suruaca e Riacho. Estes solos possuem horizonte superficial com alto teor e espessura de matéria orgânica sobre camada fortemente gleyzada (tabatinga). Apresentam lençol freático elevado devido à má drenagem natural, necessitando de obras de drenagem em caso de utilização agrícola. Pelo seu alto teor de matéria orgânica, com elevada acidez, necessitam de altas doses de corretivos e, conseqüentemente, investimentos substanciais para o caso de aproveitamento agrícola.

A drenagem, com posterior uso agrícola, pode provocar algumas alterações nestes solos, como a subsidência ou rebaixamento da camada orgânica, devido à decomposição acelerada desse material em condição aeróbica e o uso de máquinas pesadas. No caso do solo orgânico, pode ocorrer também combustão espontânea, em períodos de seca prolongada.

\section{- Região de Tabuleiros}

A Região de Tabuleiros caracteriza-se por apresentar relevo plano a ondulado $(0 \mathrm{a}$ $20 \%$ de declividade), possibilitando a mecanização das atividades agrícolas. Os tabuleiros são encontrados em pequenas áreas no sul do Estado, aumentando gradativamente na medida em que se desloca em direção ao norte, encontrando na porção acima do Rio Doce, a sua maior extensão.

Os solos de Tabuleiros, devido a sua origem sedimentar, são heterogêneos, revelando-se em sua maioria ácidos e de baixa fertilidade.

Nesta região predomina o Latossolo Vermelho-Amarelo distrófico coeso e algumas manchas de Podzólico Vermelho-Amarelo abrupto e integradas entre estas duas unidades de solos. A principal característica desses solos é o alto grau de coesão natural, expresso especialmente nas superfícies expostas dos cortes das estradas, englobando a base do horizonte superficial (horizonte A) e todo o horizonte subsuperficial (horizonte B). Essa camada adensada e argilosa que se inicia em profundidade variada, normalmente de 10 a 25 centímetros, dificulta a permeabilidade da água e o enraizamento de plantas, facilitando o processo de erosão.

A diferença básica entre esses solos é o gradiente textural entre os horizontes $\mathrm{A}$ e $\mathrm{B}$. Enquanto no Latossolo a relação textural B/A gira em torno de 2,0, nos Podzólicos essa relação está em torno de 7,0 . Isso significa que existe uma boa drenagem e facilidade de enraizamento das plantas na camada superficial, e dificuldade na camada adensada (subsuperficial), sendo estas características mais acentuadas no Podzólico. Outra característica importante desses solos é o aumento drástico dos teores de alumínio trocável com o aumento da profundidade. Ocorre também, de forma freqüente, os paleocupinzeiros (murundus), que dificultam a movimentação de máquinas e são mais pobres em fertilidade que a região circunvizinha.

A vantagem desses solos, além do relevo, é a de se caracterizar como sistema conservador de nutrientes, isto é, a perda de nutrientes por escorrimento vertical e lateral é pequena, em virtude da topografia pouco acidentada e pela baixa permeabilidade do solo na camada subsuperficial.

Existem também, na região, pequenas manchas dispersas de solos eutróficos (Latossolo Vermelho-Escuro) em relevo suave ondulado, apresentando alto potencial agronômico devido as suas propriedades físicas e químicas. 


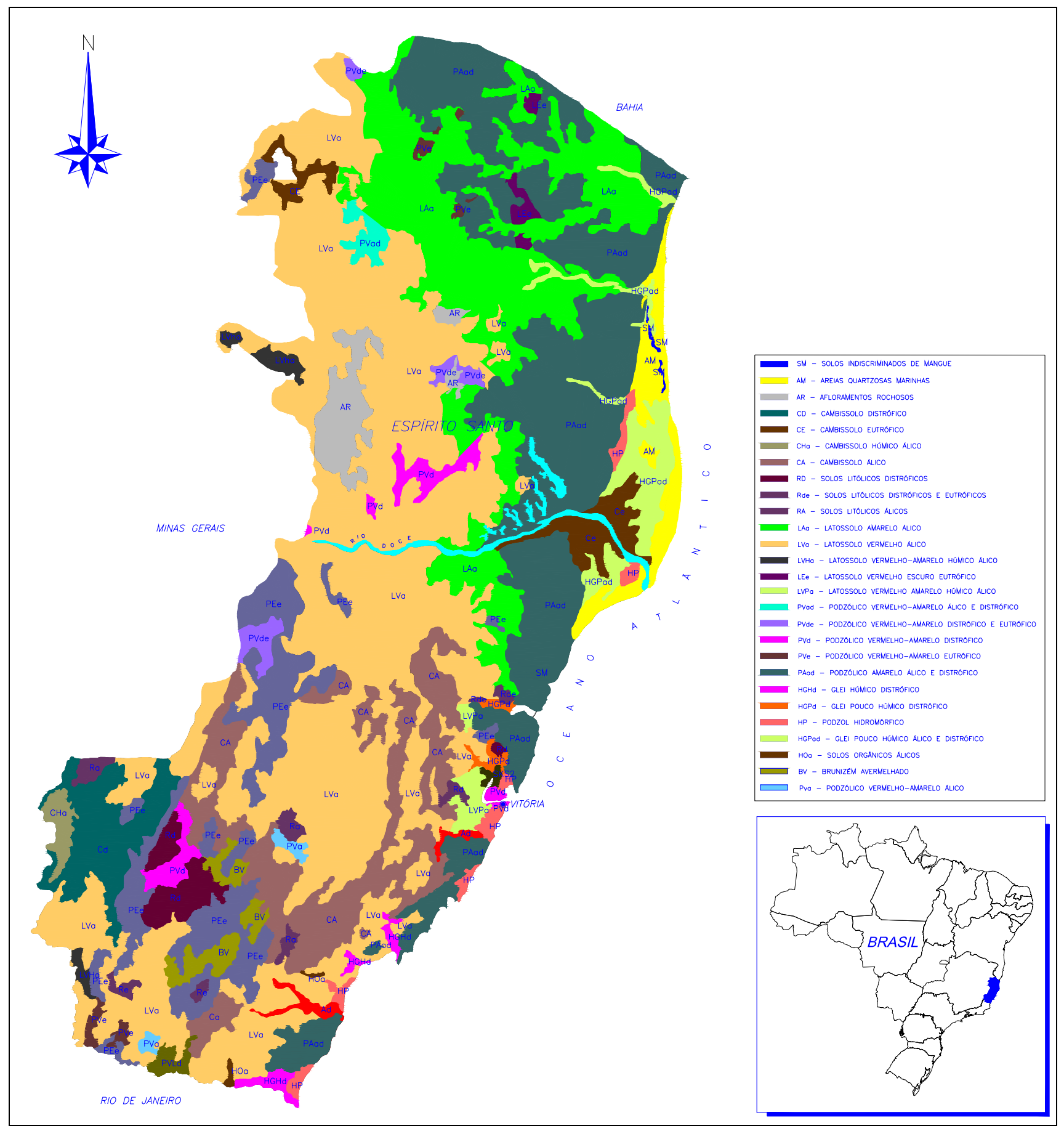

Figura 6: Mapa de Solos do Espírito Santo

Fonte: Mapa Exploratório de Solos, Folhas SE:24 - Rio Doce (IBGE, 1987); SE: 23/24 - Rio de Janeiro , Vitória (RADAMBRASIL, 1983). 


\section{- Região Elevada Interior}

- Sul

O solo predominante desta região é o Latossolo Vermelho-Amarelo distrófico, ocorrendo principalmente nas áreas de encostas sujeitas a uma maior precipitação pluviométrica. Caracterizam-se, sob o ponto de vista agronômico, por possuírem boa permeabilidade, boa drenagem, alta friabilidade e baixa erodibilidade quando argiloso, devido à alta estabilidade de agregados. Apesar da baixa erodibilidade, podem ter elevadas perdas de solo por erosão, em razão do relevo predominantemente montanhoso das áreas onde ocorrem. Em termos de características químicas, apresentam baixos teores de nutrientes com elevada acidez e baixa reserva mineral.

Nessa região também são encontrados solos com o horizonte B textural eutrófico (Terra Roxa, Brunizem Avermelhado e Podzólico Vermelho-Amarelo eutrófico) que possuem boas características químicas (baixa acidez, elevada fertilidade e moderada a alta reserva mineral). Ainda nesse caso, as características físicas são ruins na maioria das áreas, devido à presença de horizonte subsuperficial (horizonte B), com um elevado grau de endurecimento que dificulta a penetração das raízes e da água, facilitando o processo de erosão. Esses solos, apesar da média à alta erodibilidade, possuem uma capacidade de recuperação rápida, em função da alta produção biológica. Além disso, a erosão é menos prejudicial a esses solos por serem eutróficos praticamente em todo o perfil. Essas classes de solos são encontradas, geralmente, nas regiões acidentadas de baixa altitude e de clima seco, de forma dispersa, em manchas de diferentes tamanhos.

São encontrados também os Cambissolos distróficos em associação com Latossolos pouco profundos, possuindo, em sua maioria, características físicas ruins (reduzida profundidade e alta desagregação) e elevada susceptibilidade à erosão, devido às condições físicas e ao relevo acidentado, além da baixa fertilidade e elevada acidez, apresentando na maioria das áreas o caráter álico (mais de 50\% de saturação de alumínio).

Nos fundos dos vales são encontrados ainda, os solos de baixada (Aluviais e Hidromórficos) que, apesar de distróficos em sua maioria, constituem-se nos solos mais ricos da paisagem que os circundam.

Os solos aluviais encontram-se, em sua maioria, nas partes mais altas da várzea, onde não ocorre inundação freqüente, apresentando grande heterogeneidade física e química, tanto na horizontal como em profundidade, devido à natureza do material sedimentar que os formam (sedimentos fluviais argilo-arenosos).

Os solos hidromórficos (Gley Pouco Húmico, Húmico e Orgânico), estão situados nas partes mais baixas da várzea, tendo a água influência marcante na formação dos mesmos, através da oscilação do lençol freático. Caracterizam-se por apresentar camada superficial rica em matéria orgânica sobre horizontes pobres em matéria orgânica e ricos em material mineral gleysado (cor cinza), geralmente argiloso, denominado popularmente de barro branco ou tabatinga. Essa argila, quando umedecida, molda-se facilmente e, quando volta a secar, mantém a forma moldada. Isso mostra a facilidade de compactação, quando submetida à pressão. Esses solos, em sua grande maioria, possuem elevada acidez e baixos teores de nutrientes, tendo destaque negativo para a camada argilosa (tabatinga), devido à sua extrema pobreza química.

- Norte

Predomina também, nesta região, o Latossolo Vermelho-Amarelo distrófico, principalmente em locais de encostas com declividade entre 20 a $45 \%$ (relevo forte ondulado) e clima predominantemente seco.

Apesar da maioria desses solos possuírem relevo menos íngreme que o da região anterior, é mais vulnerável à erosão por possuir características físicas que favorecem $o$ desenvolvimento dos processos erosivos, como a textura mais grosseira e maior desagregação, além do clima mais seco proporcionar menor cobertura ao solo durante o ano, deixando-o mais exposto à erosão. Possuem, em sua maioria, baixa fertilidade e acidez média a alta. Em alguns locais, esses solos apresentam elevados teores de nutrientes e baixa acidez. São menos pobres quimicamente que os Latossolos da região elevada Interior - sul.

Os Latossolos dessa região, dispersos em toda a região norte, encontram-se concentrados em alguns locais, como no Município de Pancas. Representam uma área 
significativa em alguns municípios e devem ser destinados prioritariamente à preservação da fauna e flora, pois são áreas muito susceptíveis à erosão e de limitadas condições ao manejo racional.

Nessa região ocorre também, de forma dispersa, os solos eutróficos (Terra Roxa e Podzólico eutrófico), além de solos de baixadas (Aluviais e Hidromórficos), com características semelhantes às relatadas para a região Elevada Interior - sul.

\subsection{3 - Recursos Hídricos Superficiais}

O Estado do Espírito Santo é constituído por uma rede hidrográfica composta por 19 rios principais (quadro 8) dos quais 4 são de jurisdição federal (Rios Itabapoana, Doce, São Mateus e Itaúnas), e os demais de jurisdição estadual.

Quadro 8: Caracterização das Principais Bacias do Estado

\begin{tabular}{|c|c|c|c|c|c|c|c|}
\hline \multirow{2}{*}{ RIO } & \multirow{2}{*}{$\mathbf{N}^{\mathbf{o}}$} & \multirow{2}{*}{$\begin{array}{c}\text { ÁREA DE } \\
\text { DRENAGEM } \\
\left(\mathbf{k m}^{2}\right) \\
\end{array}$} & \multirow{2}{*}{$\%$} & \multicolumn{3}{|c|}{ VAZÕES $\left(\mathrm{m}^{3} / \mathrm{s}\right)$} & \multirow{2}{*}{$\begin{array}{c}\text { ESTAÇÕES } \\
\text { FLUVIOMÉTRICAS }\end{array}$} \\
\hline & & & & MÍN. & MÁX. & MÉDIA & \\
\hline Itaúnas & 1 & $4.361,00$ & 9,44 & - & - & - & \\
\hline São Mateus & 2 & $7.709,10$ & 16,69 & 1,00 & 640,00 & 21,00 & São João e Boa Esperança \\
\hline Barra Seca & 3 & $3.373,60$ & 7,31 & 4,00 & 330,00 & 50,00 & Ponte do Barra Seca \\
\hline Doce & 4 & $12.601,20$ & 27,28 & 183,00 & $6.585,00$ & 971,30 & Colatina \\
\hline Riacho & 5 & $1.380,10$ & 2,99 & - & - & - & - \\
\hline Piraquê-açú & 6 & 482,70 & 1,05 & - & - & - & - \\
\hline Reis Magos & 7 & 943,20 & 2,04 & - & - & - & - \\
\hline Sta. M. da Vitória & 8 & $1.816,80$ & 3,93 & 0,76 & 200,00 & 13,40 & Santa Leopoldina \\
\hline Jucú & 9 & $2.214,50$ & 4,80 & 5,36 & 525,00 & 16,50 & Jucuruaba \\
\hline Guarapari & 10 & 316,10 & 0,68 & - & - & - & - \\
\hline Benevente & 11 & $1.203,30$ & 2,61 & 1,48 & 64,40 & 5,30 & Alfredo Chaves \\
\hline Novo & 12 & 764,80 & 1,66 & 1,80 & 68,20 & - & Pau D'alho \\
\hline Itapemirim & 13 & $5.819,20$ & 12,60 & 6,01 & 945,00 & 73,10 & Itapemirim \\
\hline Itabapoana & 14 & $3.198,20$ & 6,92 & 2,20 & 604,00 & 50,10 & Ponte do Itabapoana \\
\hline TOTAL & - & $46.183,80$ & 100,00 & - & - & - & - \\
\hline
\end{tabular}

\section{2 - Meio Biológico}

\subsection{1 - Flora}

Predominam no Espírito Santo cinco diferentes tipos de formações vegetais (figura 7):

- Floresta Ombrófila Densa - Ocorre em todo o território capixaba, sendo que no norte do Estado, apresenta-se com aspecto mais pujante, recebendo a denominação de floresta dos tabuleiros. Existe grande semelhança deste tipo florestal com a hiléia amazônica. Os ambientes apresentam chuvas bem distribuídas, com médias anuais em torno de $1.500 \mathrm{~mm}$, havendo estações sem seca e com grande disponibilidade de umidade. Foi intensamente devastada desde a época do descobrimento, portanto, os vestígios da vegetação original são encontrados apenas em áreas muito restritas.

Como espécies arbóreas características desta tipologia de vegetação, pode-se mencionar: o ipê (Tabebuia obstusiofila), a canela (Nectandra spp.), o jatobá (Himenaea sp.), a sapucaia (Lecythis spp.), o jacarandá (Dalbergia nigra), a barriga-d'água (Hidrogaster trinerve), o cedro (Cedrela fissilis), o jequitibá (Cariniana sp.) e o paubrasil (Caesalpinia echinata), este último muito explorado no início da colonização do Estado e hoje ameaçado de extinção. Nas áreas de maior altitude se destacam a canjerana (Cabralea sp.) e sangue de drago (Croton sp.), além de várias espécies das famílias Melastomataceae e Lauraceae. 


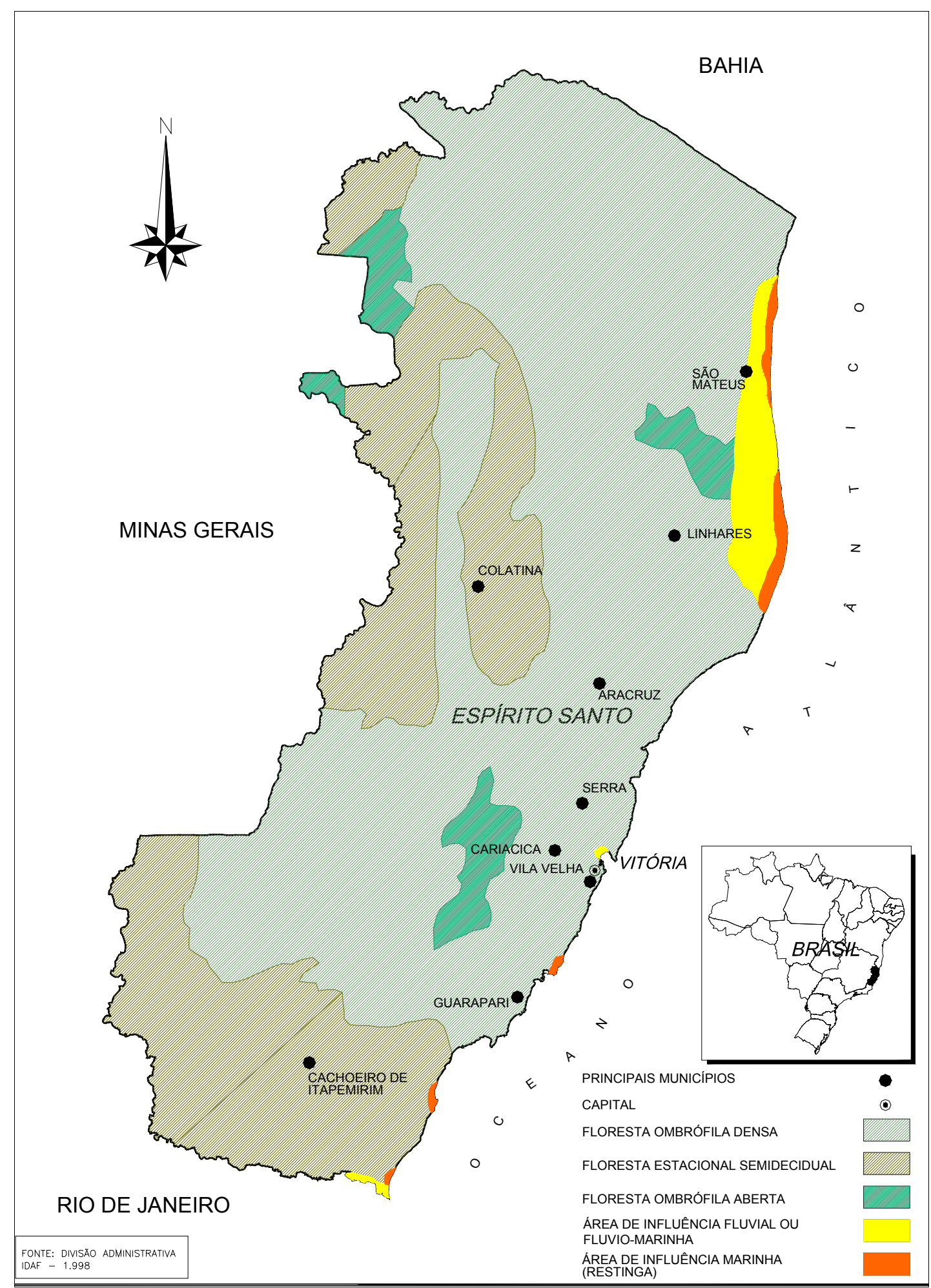

Figura 7: Distribuição das Formações Vegetais no Estado 
- Floresta Ombrófila Aberta - apresenta-se em pequenas manchas na porção central e na região noroeste do Espírito Santo. O caráter aberto da floresta é estabelecido pela palmeira Attalea sp., conhecida localmente por indaiá-açú. Esta floresta ocorre no Planalto do Caparaó, em altitudes que variam de 600 a $1.200 \mathrm{~m}$. Nas partes mais baixas, ela ocorre na forma de floresta de grande porte, com espécies características como o ingá (Ingá sp.), o jacatirão (Miconia sp.), o cedro (Cedrela sp.), a canela (Ocotea spp. e Nectandra sp.), o jequitibá-branco (Cariniana sp.) e o palmito (Euterpe edulis). A maior parte desse ambiente tem dado lugar à vegetação secundária com palmeiras ou às pastagens.

- Floresta Estacional Semidecidual tipologia predominante no extremo sul, ocorrendo também no extremo oeste e na região central do Estado do Espírito Santo. Entre as espécies que se destacam nessa tipologia, tem-se: a peroba (Aspidosperma sp.), o cedro (Cedrella fissilis), a canela (Nectandra sp.), o araribá (Sinckingia sp.), o jatobá (Himenaea sp.) e a paineira (Chorisia speciosa). No Estado observamse locais preservados com esta formação vegetal, principalmente em Unidades de Conservação ou em áreas de preservação permanente de propriedades rurais.

- Áreas com Influência Fluvial ou Flúvio Marinha - são encontradas ao longo do litoral do Estado, principalmente na parte norte deste. Constituem os ambientes da desembocadura dos cursos de água no mar (influência flúvio-marinha) ou áreas de acumulação dos cursos de água, lagoas e semelhantes, que constituem os terraços aluviais sujeitos ou não às inundações periódicas (influência fluvial). Nas áreas flúvio-marinhas, ocorre o desenvolvimento do mangue, já as áreas fluviais geralmente apresentam fisionomia arbustiva ou herbácea, com a predominância dos gêneros Typha, Cyperus e Eleocharis.

- Áreas com Influência Marinha (Restinga) - ocupam uma faixa de largura variável ao longo do litoral capixaba, juntamente com áreas de influência fluvial ou flúvio-marinha. Recobrindo as mesmas, encontra-se uma vegetação de grande diversidade fisionômica, variando desde cobertura rasteira, em áreas fortemente arenosas, até florestas de caráter esclerófilo ou pantanoso, em áreas mais úmidas. Alguns gêneros característicos desta formação vegetal são Eugenia, Psidium, Miconia e Nectandra, nas formações de caráter esclerófilo, e Tabebuia, Erythrina e Jacaranda, nos lugares mais úmidos.

Historicamente, o Estado do Espírito Santo sofreu um indiscriminado processo de desmatamento, o qual foi acelerado nas décadas de 50 a 70. A partir de meados da década de 80 houve uma expressiva redução no nível de desmatamento de florestas naturais, devido à fiscalização mais intensa exercida pelo Estado e às pressões ambientalistas (quadro 9). Porém, mesmo com essa redução, restaram no Estado 371.862 ha de florestas nativas, ou seja, $8 \%$ do território (IBGE, 1975).

Outra consideração importante é que desses 371.862 ha de florestas nativas, $124.740,8$ ha $(33,54 \%$ da área com floresta no Estado) correspondem a Unidades de Conservação, enquanto que a área restante (247.121,2 ha), está sob o domínio privado.

Quadro 9: Área Coberta por Florestas Nativas no Estado

\begin{tabular}{|c|c|c|}
\hline \hline ANO & ÁREA (ha) & \% $^{(\mathbf{1})}$ \\
\hline \hline 1975 & 439.628 & 9,5 \\
\hline 1985 & 399.274 & 8,6 \\
\hline 1995 & 371.862 & 8,0 \\
\hline \hline
\end{tabular}

(1) Em relação à área total do Estado do Espírito Santo Fonte: IBGE (1975, 1985 e 1995) 


\subsection{2 - Fauna}

Para a melhor compreensão da distribuição da fauna no Estado, procedeu-se à análise das espécies por ecossistemas ou ambientes de ocorrência e por classes sistemáticas. (BERNARDES, 1990; COSTA, 1980; IBAMA, 1989; IBDF, 1981 e VENTURINI, 1996)

- Floresta ombrófila densa (Mata Atlântica) e floresta ombrófila aberta onde são encontrados animais típicos de floresta úmida, como a preguiça-decoleira (Bradypus torquatus), a harpia (Harpia harpyja) e o mono-carvoeiro (Brachyteles arachnoides);

- Floresta estacional semidecidual - habitat do veado-mateiro (Mazama americana), da queixada (Tayassu pecari), da onça suçuarana (Puma concolor) e da seriema (Cariama cristatas);

- Restinga - ambiente morfoclimático da mata atlântica onde a fauna, é composta por espécies ecléticas (capacidade de utilizar vários ambientes distintos) e restritas (utilizam apenas um tipo de ambiente) (VENTURINI et al, 1996). Como espécies ecléticas, pode-se citar o gambá (Didelphis marsupialis), o cachorro-do-mato (Cerdocyon thous) e o gavião-nagê (Buteo magnirostris). Entre as espécies restritas encontram-se a marmosa (Gracilinanus agilis), a marreca
(Amazonetta brasiliensis) e a cuíca (Caluromys philander);

- Ambientes alterados, abertos ou com formações herbáceas - são encontrados ratos-de-campo (Oxymycterus spp.), pássaros que se alimentam de sementes e insetos como o anú (Piaya cayana) e os formigueiros (Myrmoterula spp.), e as aves de rapina dentre elas as corujas (Otus spp.) e o gavião cará-cará (Polyborus plancus);

- Ambientes aquáticos (rios, brejos, várzeas e lagos) - são típicos dessa formação o frango-d'água (Laterallus spp.), espécies de martim-pescador (Chloroceryle spp.), o cágado (Phrynops geofroyana), além de sapos e rãs; e,

- Outras espécies de mamíferos carnívoros, como é o caso da onça-pintada (Panthera onca), da onça suçuarana (Puma concolor), e de aves de rapina (gaviões, urubus), que têm seus territórios delimitados em função da disponibilidade de caça, utilizam vários habitats para sobrevivência, podendo ser encontrados tanto em região de florestas como em áreas abertas ou alteradas.

No que se refere às espécies raras, em perigo ou ameaçadas de extinção, no quadro 10 é apresentada uma lista dessas espécies, bem como sua categoria e ocorrência em unidades de conservação.

Quadro 10: Enquadramento de Algumas Espécies Ameaçadas de Extinção Segundo as Categorias da $\mathrm{UICN}^{* * *}$ e Anexos CITES

\begin{tabular}{|c|c|c|c|c|}
\hline NOME CIENTÍFICO & NOME COMUM & LOCAL DE OCORRÊNCIA & UICN & CITES \\
\hline Alouatta fusca & bugio, guariba & $\begin{array}{l}\text { R.B. Augusto Ruschi } \\
\text { R.E. Pedra Azul } \\
\text { R.B. Duas Bocas } \\
\text { R. Fazenda Montes Verdes } \\
\text { R.B. Santa Lúcia } \\
\text { R.B. São Lourenço }\end{array}$ & vulnerável & II \\
\hline Alouatta fusca fusca & bugio & $\begin{array}{l}\text { R.F. Linhares (CVRD) } \\
\text { R.B. Sooretama }\end{array}$ & em perigo & II \\
\hline Brachyteles arachnoides & mono-carvoeiro, muriqui & R.B. Augusto Ruschi & em perigo & $\mathrm{I}$ \\
\hline Bradypus torquatus & preguiça-de-coleira & $\begin{array}{l}\text { R.B. Augusto Ruschi } \\
\text { R.B. Pedra Azul* } \\
\text { R.B. Duas Bocas* } \\
\text { R.B. Santa Lúcia } \\
\text { R.B. Sooretama** } \\
\text { R.F. Linhares (CVRD)** } \\
\text { R.B. Mestre Álvaro** } \\
\text { A.P. Goitacazes** }\end{array}$ & em perigo & n.c. \\
\hline
\end{tabular}


Quadro 10: Enquadramento de Algumas Espécies Ameaçadas de Extinção Segundo as Categorias da UICN*** e Anexos CITES (Continuação)

\begin{tabular}{|c|c|c|c|c|}
\hline NOME CIENTÍFICO & NOME COMUM & LOCAL DE OCORRÊNCIA & UICN & CITES \\
\hline Callicebus personatus & guigó, sauá & $\begin{array}{l}\text { P.N. Caparaó } \\
\text { R.B. Sooretama } \\
\text { R.B. Augusto Ruschi } \\
\text { R.F. Linhares } \\
\text { R.E. Pedra Azul } \\
\text { R.E. Duas Bocas } \\
\text { R. Fazenda Montes Verdes } \\
\text { E.B. Santa Lúcia } \\
\text { E.B. São Lourenço } \\
\text { Arreas da ARACRUZ }\end{array}$ & vulnerável & II \\
\hline Callithrix aurita & sagui-da-serra-escuro & - & em perigo & $\mathrm{I}$ \\
\hline Callithrix flaviceps & sagui-da-serra & $\begin{array}{l}\text { R.B. Augusto Ruschi } \\
\text { R.B. Pedra Azul } \\
\text { P.E. Forno Grande } \\
\text { R.B. Santa Lúcia } \\
\text { R.B. São Lourenço }\end{array}$ & em perigo & I \\
\hline Chaetomys subspinosus & ouriço-preto & $\begin{array}{l}\text { R.B. Sooretama } \\
\text { R.B. Comboios } \\
\text { R.B. Augusto Ruschi } \\
\text { P.E. Forno Grande } \\
\text { R.F. Mestre Álvaro } \\
\text { R.F. Duas Bocas } \\
\text { R.F. Pedra Azul } \\
\text { R.F. Bananal do Norte }\end{array}$ & vulnerável & n.c. \\
\hline Puma concolor & suçuarana & $\begin{array}{l}\text { P.E. Paulo César Vinha } \\
\text { P.N. Caparão } \\
\text { R.F. Linhares (CVRD) } \\
\text { R.B. Sooterama }\end{array}$ & em perigo & \\
\hline Felis pardalis & jaguatirica & $\begin{array}{l}\text { P.E. Paulo César Vinha P.N. Caparaó } \\
\text { R.F. Linhares (CVRD)** } \\
\text { R.B. Sooterama }\end{array}$ & em perigo & \\
\hline Felis tigrina & gato-do-mato & - & $\begin{array}{l}\text { insufic. } \\
\text { conhecida }\end{array}$ & II \\
\hline Felis wedii & maracajá & $\begin{array}{l}\text { P.N. Caparaó } \\
\text { R.B. Sooretama }\end{array}$ & $\begin{array}{l}\text { insufic. } \\
\text { conhecida }\end{array}$ & II \\
\hline Leucopternis polionota & gavião-pombo & Áreas da ARACRUZ & n.c. & \\
\hline Lutra longicaudis & lontra & $\begin{array}{l}\text { R.B. Duas Bocas } \\
\text { R.B. Sooretama } \\
\text { R.E. Santa Lúcia }\end{array}$ & vulnerável & I \\
\hline Myrmecophaga tridactyla & tamanduá-bandeira & $\begin{array}{l}\text { R.B. Sooretama } \\
\text { R.B. Córrego do Veado }\end{array}$ & vulnerável & II \\
\hline Panthera onca & onça-pintada & $\begin{array}{l}\text { R.B. Sooretama } \\
\text { R.F. Linhares }\end{array}$ & n.c. & I \\
\hline Procnias nudicollis & araponga & Áreas da ARACRUZ & n.c. & \\
\hline Pteronura brasiliensis & ariranha & $\begin{array}{l}\text { R.B. Sooretama } \\
\text { R.B. Córrego do Veado }\end{array}$ & vulnerável & I \\
\hline Turdus fumigatus & sabiá-da-mata & Áreas da ARACRUZ & n.c. & \\
\hline
\end{tabular}

* introdução ou reintrodução

** suspeita de ocorrência

***UICN = União Internacional para a Conservação da Natureza

n.c.: não consta

Fonte: MMA/IBAMA, 1995; FONSECA et. al., 1994; Aracruz Celulose S.A. - Relatórios de 1995, 1996,1998 e 1999 do Projeto Monitoramento de Microbacia 


\section{3 - Regiões Bioclimáticas}

No presente tópico serão descritas as 10 Regiões Bioclimáticas definidas para o Estado, com suas potencialidades, restrições e recomendações para o uso sustentado dos recursos existentes (quadro 11 e figura 8). A definição dessas regiões foi embasada nas seguintes informações existentes e disponíveis:

- Carta Agroclimática do Estado do Espírito Santo (EMCAPA, 1986);

- Mapeamento de solos contido no Projeto RADAMBRASIL (1986);

- Análise da cobertura florestal original do Estado;

- Mapa de aptidão dos solos do Estado do Espírito Santo (DADALTO, BARBOSA \& SARTORI, 1992);

- Informações levantadas no Diagnóstico Ambiental e do Programa de Fomento Florestal; e,

- Análise de espécies exóticas e nativas do Estado ou do Brasil, aptas ecológica e economicamente para utilização no Espírito Santo.

\section{4 - Meio Socioeconômico}

\subsection{1 - População}

A população residente no Estado do Espírito Santo é de aproximadamente 2,8 milhões de habitantes, correspondendo a 1,8\% da população brasileira (IBGE, 1996). É interessante ressaltar que $64 \%$ são economicamente ativos (1,8 milhões); cerca de $78 \%$ concentram-se na zona urbana e $22 \%$ na zona rural.

A população residente na área de influência do Programa de Fomento corresponde a 1.339 .332 habitantes $(48 \%$ da população do Estado), destes $66,5 \%$ habita na zona urbana e $33,5 \%$ habita na zona rural.

Ao comparar-se a distribuição populacional do Estado em relação à área de influência do Programa de Fomento, percebese um aumento proporcional em torno de $11 \%$ na distribuição da população rural. Dessa forma, fica evidente a necessidade de programas que incentivem a fixação da população na área rural, sendo o Programa de
Fomento Florestal da Aracruz uma importante ferramenta para atingir esse objetivo, no momento em que o perfil dos produtores participantes desde a implantação do Programa é composto, principalmente, de propriedades menores que 100 ha.

Outro fator a ser considerado é a faixa etária da população residente na área de influência do Programa, $33 \%$ da população concentra-se na faixa etária de 0 a 14 anos e $44 \%$ na faixa etária de 14 a 39 anos, o que evidencia o perfil jovem e de grande potencial produtivo da população.

\subsection{2 - Infra-Estrutura}

\subsubsection{1 - Transportes}

O desenvolvimento da economia capixaba está bastante vinculado a um complexo logístico de transporte que liga o Estado a diferentes regiões do Brasil e ao exterior, sendo um dos Estados brasileiros com a melhor infra-estrutura de transporte, haja vista sua localização, aliada a excelente logística de transporte, com destaque para:

- Transporte Rodoviário - malha rodoviária de $30.000 \mathrm{~km}$, correspondendo a $1,8 \%$ da malha nacional $(1.657 .769 \mathrm{~km})$. A relação entre a extensão da malha rodoviária $\mathrm{e}$ área total do Estado, posiciona $\mathrm{o}$ Espírito Santo em segundo lugar no índice nacional $\left(0,65 \mathrm{~km} / \mathrm{km}^{2}\right)$, perdendo apenas para o Estado de São Paulo $\left(0,78 \mathrm{~km} / \mathrm{km}^{2}\right)$. Do total das rodovias existentes mais de $80 \%$ são municipais, $16 \%$ são estaduais e $2,6 \%$ federais.

- Transporte Ferroviário - malha ferroviária de $522 \mathrm{~km}$, respondendo por cerca de $1,8 \%$ da malha nacional $(29.225 \mathrm{~km})$. Apesar de uma malha reduzida, a logística do transporte ferroviário interagindo com outras modalidades de transporte (rodoviário e marítimo), permite que o Espírito Santo ocupe posição de destaque frente aos demais Estados brasileiros. 
Quadro 11: Descrição das Regiões Bioclimáticas Definidas para o Estado

\begin{tabular}{|c|c|c|c|c|c|c|c|c|c|c|}
\hline \multirow{2}{*}{$\begin{array}{c}\text { REGIÕES } \\
\text { BIOCLIMÁTICAS }\end{array}$} & \multirow{2}{*}{ LOCALIZAÇÃO } & \multirow{2}{*}{ ALTITUDE } & \multirow{2}{*}{ RELEVO } & \multirow{2}{*}{$\begin{array}{l}\text { CLIMA* } \\
\text { (Köppen) }\end{array}$} & \multicolumn{2}{|c|}{$\begin{array}{l}\text { TEMPERATURA } \\
\left({ }^{\circ} \mathrm{C}\right)\end{array}$} & \multirow{2}{*}{\begin{tabular}{|l} 
PRECIPITAÇÃO \\
ANUAL (MM)
\end{tabular}} & \multirow{2}{*}{$\begin{array}{l}\text { DÉFICIT } \\
\text { HIIDRICO } \\
\text { (MM) }\end{array}$} & \multirow{2}{*}{ SOLO DOMINANTE } & \multirow{2}{*}{ VEGETAÇÃO } \\
\hline & & & & & $\begin{array}{l}\text { Média } \\
\text { Mínima }\end{array}$ & $\begin{array}{c}\text { Média } \\
\text { Máxima }\end{array}$ & & & & \\
\hline REGIÃO “1” & Litoral do Estado & 0 a $100 \mathrm{~m}$ & $\begin{array}{l}\text { Topografia } \\
\text { plana }\end{array}$ & Aw e Am & 15,0 & 32,0 & 2.184 & $\begin{array}{l}\text { Não } \\
\text { apresenta }\end{array}$ & - Arenosos (Areias Quartzosas) & $\begin{array}{l}\text { - Floresta Ombrófila } \\
\text { Abertas; e, } \\
\text { - Floresta Ombrófila } \\
\text { Densa. }\end{array}$ \\
\hline REGIÃO “2” & Litoral do Estado & 0 a $200 \mathrm{~m}$ & $\begin{array}{l}\text { Topografia } \\
\text { plana }\end{array}$ & Aw e Am & 15,0 & 32,0 & 1.080 e 2.142 & $\begin{array}{l}\text { Não } \\
\text { apresenta }\end{array}$ & - Hidromóficos e Aluviais & $\begin{array}{l}\text { - Floresta Ombrófila } \\
\text { Abertas; e, } \\
\text { - Floresta Ombrófila } \\
\text { Densa. }\end{array}$ \\
\hline REGIÃO “3” & $\begin{array}{l}\text { Noroeste, Centro e } \\
\text { Sul do Estado }\end{array}$ & 100 a $1.000 \mathrm{~m}$ & $\begin{array}{l}\text { Plano a } \\
\text { ondulado }\end{array}$ & $\begin{array}{l}\text { Am, Aw, } \\
\text { Cwa e } \\
\text { Cwb }\end{array}$ & 13,3 & 34,0 & 1.058 a 1.423 & 139 a 372 & $\begin{array}{l}\text { - } \text { Latossolo Vermelho-Amarelo distrófico coeso; } \\
\text { - Podzólico Vermelho-Amarelo abrupto; } \\
\text { - } \text { Latossolo Vermelho-Escuro, horizonte B } \\
\text { textural eutrófico; } \\
\text { - } \text { Cambissolos distróficos; } \\
\text { - } \text { Aluviais e Hidromórficos. }\end{array}$ & $\begin{array}{l}\text { - Floresta Ombrófila } \\
\text { Densa; e, } \\
\text { - Floresta Estacional } \\
\text { Semidecidual. }\end{array}$ \\
\hline REGIÃO “4” & $\begin{array}{l}\text { Centro-Norte do } \\
\text { Estado }\end{array}$ & 0 a $200 \mathrm{~m}$ & $\begin{array}{l}\text { Plano a } \\
\text { ondulado }\end{array}$ & $\begin{array}{l}\text { Aw e } \\
\text { Cwa }\end{array}$ & 11,8 & 34,0 & 970 a 1.310 & 224 a 448 & $\begin{array}{l}\text { - Latossolo Vermelho-Amarelo distrófico coeso; } \\
\text { - Podzólico Vermelho-Amarelo abrupto. }\end{array}$ & $\begin{array}{l}\text { - Floresta Ombrófila } \\
\text { Densa; } \\
\text { - Floresta Ombrófila } \\
\text { Aberta; e, } \\
\text { - } \begin{array}{l}\text { Floresta Estacional } \\
\text { Semidecidual }\end{array}\end{array}$ \\
\hline REGIÃO “5” & $\begin{array}{c}\text { Centro-Oeste e } \\
\text { Noroeste do Estado }\end{array}$ & 80 a $800 \mathrm{~m}$ & Montanhoso & $\begin{array}{l}\text { Aw e } \\
\text { Cwa }\end{array}$ & 10,9 & 33,5 & 842 a 1.197 & 210 a 606 & $\begin{array}{l}\text { - Latossolo Vermelho-Amarelo distrófico coeso; } \\
\text { - Podzólico Vermelho-Amarelo abrupto, } \\
\text { horizonte B textural eutrófico; } \\
\text { - } \text { Cambissolos distróficos; } \\
\text { - } \\
\text { Aluviais e Hidromórficos. }\end{array}$ & $\begin{array}{l}\text { - Floresta Ombrófila } \\
\text { Densa; } \\
\text { - Floresta Ombrófila } \\
\text { Aberta; e, } \\
\text { - } \begin{array}{l}\text { Floresta Estacional } \\
\text { Semidecidual }\end{array}\end{array}$ \\
\hline
\end{tabular}


Estudo ambiental para os programas de fomento...

Quadro 11: Descrição das Regiões Bioclimáticas Definidas para o Estado (Continuação)

\begin{tabular}{|c|c|c|c|c|c|c|c|c|c|c|}
\hline \multirow{2}{*}{$\begin{array}{c}\text { REGIÕES } \\
\text { BIOCLIMÁTICAS }\end{array}$} & \multirow{2}{*}{ LOCALIZAÇÃO } & \multirow{2}{*}{ ALTITUDE } & \multirow{2}{*}{ RELEVO } & \multirow{2}{*}{$\begin{array}{l}\text { CLIMA* } \\
\text { (Köppen) }\end{array}$} & \multicolumn{2}{|c|}{$\begin{array}{c}\text { TEMPERATURA } \\
\left({ }^{\circ} \mathrm{C}\right) \\
\end{array}$} & \multirow{2}{*}{$\begin{array}{l}\text { PRECIPITAÇÃO } \\
\text { ANUAL (MM) }\end{array}$} & \multirow{2}{*}{$\begin{array}{l}\text { DÉFICIT } \\
\text { HIIDRICO } \\
\text { (MM) }\end{array}$} & \multirow{2}{*}{ SOLO DOMINANTE } & \multirow{2}{*}{ VEGETAÇÃO } \\
\hline & & & & & \begin{tabular}{|c|} 
Média \\
Mínima \\
\end{tabular} & $\begin{array}{c}\text { Média } \\
\text { Máxima }\end{array}$ & & & & \\
\hline REGIÃO “6” & $\begin{array}{l}\text { Noroeste, Centro e } \\
\text { Sul do Estado }\end{array}$ & 100 a $1.000 \mathrm{~m}$ & Montanhoso & $\begin{array}{l}\text { Cwa, } \\
\text { Cwb, Aw } \\
\text { e Am }\end{array}$ & 8,5 & 33,5 & 1.083 a 1.592 & 56 a 191 & $\begin{array}{l}\text { - Latossolo Vermelho álico; } \\
\text { - Cambissolo distrófico; } \\
\text { - Latossolos pouco profundos; } \\
\text { - Aluviais e Hidromórficos; e, } \\
\text { - Latossolo Vermelho-Amarelo húmico álico }\end{array}$ & $\begin{array}{l}\text { - Floresta Ombrófila } \\
\text { Densa; } \\
\text { - Floresta Ombrófila } \\
\text { Aberta; e, } \\
\text { - Floresta Estacional } \\
\text { Semidecidual }\end{array}$ \\
\hline REGIÃO “7” & Centro-Sul do Estado & 600 a $1.400 \mathrm{~m}$ & $\begin{array}{l}\text { Áreas } \\
\text { planálticas } \\
\text { isoladas }\end{array}$ & $\begin{array}{l}\text { Cfb, Cwb, } \\
\text { Cwa e } \\
\text { Cfa }\end{array}$ & 7,3 & 27,8 & 1.083 a 1.592 & 56 a 191 & $\begin{array}{l}\text { - Latossolo Vermelho-Amarelo, horizonte B } \\
\text { textural eutrófico. } \\
\text { - Cambissolos distróficos; } \mathrm{e} \\
\text { - } \\
\text { Latossolos pouco profundos. }\end{array}$ & $\begin{array}{l}\text { - Floresta Estacional } \\
\text { Semidecidual; e, } \\
\text { - Floresta Ombrófila } \\
\text { Densa } \\
\end{array}$ \\
\hline REGIÃO “8” & Centro-Sul do Estado & 450 a $1.000 \mathrm{~m}$ & $\begin{array}{l}\text { Áreas } \\
\text { planálticas } \\
\text { isoladas }\end{array}$ & $\mathrm{Cfa}$ e Cfb & 8,5 & 27,8 & 1.597 a 2.184 & $\begin{array}{c}\text { Não } \\
\text { apresenta }\end{array}$ & $\begin{array}{l}\text { - Cambissolos distróficos; e, } \\
\text { - Latossolos pouco profundos. }\end{array}$ & $\begin{array}{l}\text { - Floresta Ombrófila } \\
\text { Densa; e, } \\
\text { - Floresta Ombrófila } \\
\text { Aberta. }\end{array}$ \\
\hline REGIÃO “9” & $\begin{array}{l}\text { Parte mais alta do } \\
\text { Estado }\end{array}$ & $\begin{array}{c}\text { Varia entre } \\
1.000 \mathrm{e} \text { acima } \\
\text { de } 1.800 \mathrm{~m}\end{array}$ & Montanhoso & $\mathrm{Cfb}$ & 6,1 & 27,6 & 1.083 a 1.592 & 56 a 191 & $\begin{array}{l}\text { - Cambissolo álico; e, } \\
\text { - Húmico álico. }\end{array}$ & $\begin{array}{l}\text { - Floresta Ombrófila } \\
\text { Densa. }\end{array}$ \\
\hline REGIÃO “10” & $\begin{array}{l}\text { Microrregiões: } \\
\text { Afonso Cláudio, } \\
\text { Cachoeiro do } \\
\text { Itapemirim e } \\
\text { Guarapari }\end{array}$ & $1.000 \mathrm{a} 1.200 \mathrm{~m}$ & $\begin{array}{l}\text { Áreas } \\
\text { planálticas } \\
\text { isoladas }\end{array}$ & $\mathrm{Cfb}$ & 7,3 & 26,7 & 1.597 a 2.184 & $\begin{array}{c}\text { Não } \\
\text { apresenta }\end{array}$ & - Latossolo Vermelho álico. & $\begin{array}{l}\text { - Floresta Ombrófila } \\
\text { Aberta. }\end{array}$ \\
\hline
\end{tabular}

* Siglas segundo a classificação climática de Köppen. 
Siqueira, J. D. P., et al

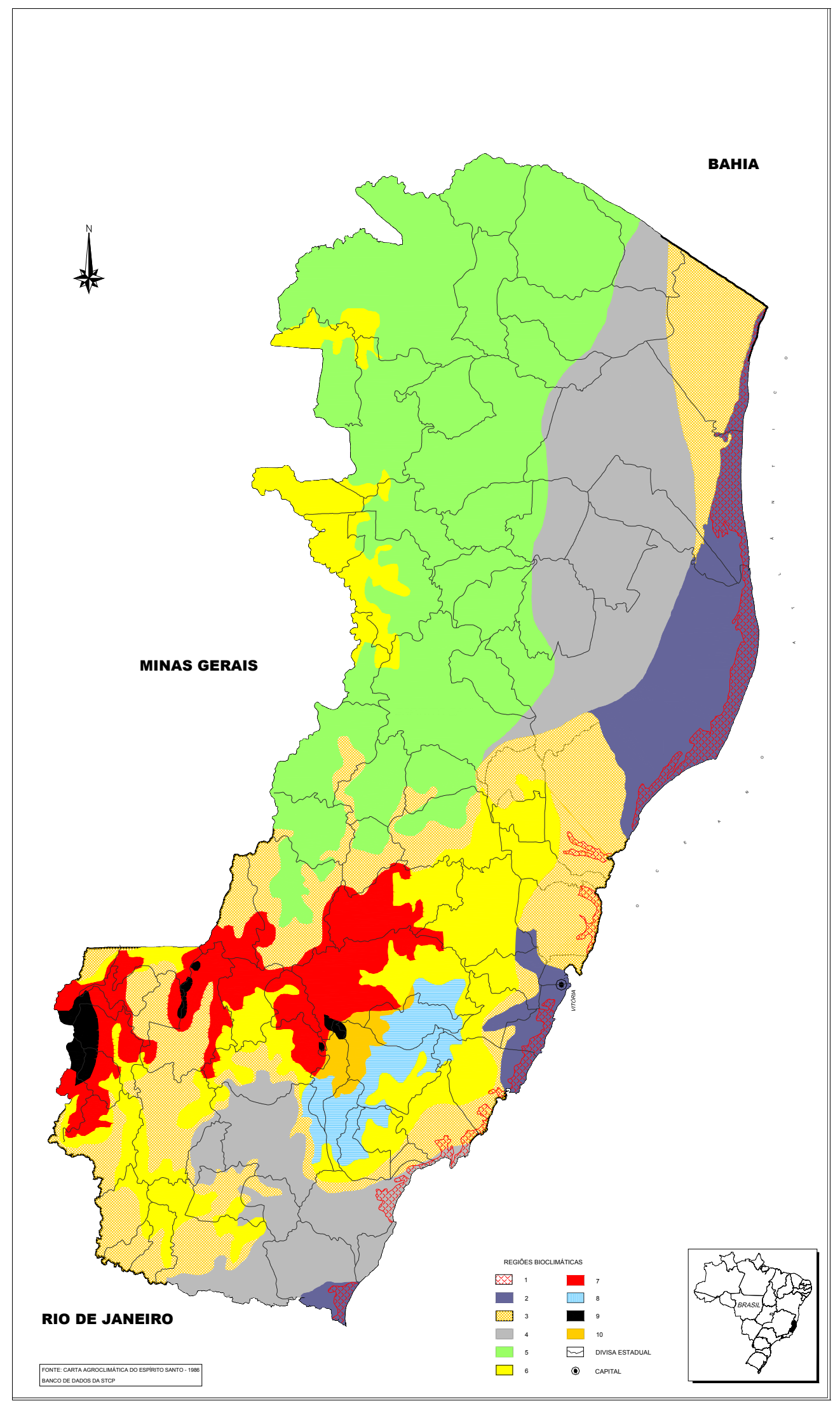

Figura 8: Distribuição das Regiões Bioclimáticas no Estado 
- Transporte Marítimo - coloca o Estado em destaque dentro do contexto nacional, tendo em vista a logística e a interação entre as diferentes modalidades de transporte. O Espírito Santo dispõe de 6 portos marítimos distribuídos ao longo de seu litoral, concentrados na porção central do Estado, sendo que o movimento das exportações pelos portos capixabas chega a US\$ 5,2 bilhões. Esse valor inclui também o escoamento de produtos provenientes de outros Estados pelo complexo portuário local, além das vendas realizadas por empresas registradas no Espírito Santo.

- Transporte Aeroviário - Aeroporto das Goiabeiras, localizado no município de Vitória, opera vôos domésticos para todas as regiões do País. Em 1996, nesse aeroporto, foram realizados aproximadamente 19.000 pousos e decolagens em vôos nacionais, movimentando cerca de 288.000 passageiros $(1,3 \%$ do número de passageiros transportados no Brasil);

- Transporte Fluvial - não é expressivo, particularmente o de cargas, porque suas bacias hidrográficas apresentam limitações quanto à navegabilidade. Os rios existentes no Estado permitem apenas a navegação de embarcações de pequeno porte, com o transporte de passageiros das comunidades ribeirinhas, de forma limitada. $O$ principal componente utilizado é o Rio Doce, preferencialmente no período de cheias;

- Estações Aduaneiras de Interior (EADI) e Terminais Portuários Intermodais (TPI) - existentes para complementar a logística de transporte do Estado.

$\mathrm{Na}$ área de Influência do Programa de Fomento, a logística de transporte é assim caracterizada:

- Transporte Rodoviário - merecem destaque as rodovias apresentadas no quadro 12 ;

Quadro 12: Rodovias Federais e Estaduais de Destaque na Área de Influência do Programa de Fomento

\begin{tabular}{|c|l|l|}
\hline \hline RODOVIA & \multicolumn{1}{|c|}{ MUNICÍPIOS SERVIDOS * } & \multicolumn{1}{|c|}{ SITUAÇÃO DE DESTAQUE } \\
\hline \hline BR-101 & $\begin{array}{l}\text { Pedro Canário, Pinheiros, Conceição da Barra, São } \\
\text { Mateus, Jaguaré, Sooretama, Linhares, Aracruz, João } \\
\text { Neiva, Ibiraçu, Fundão, Serra, }\end{array}$ & $\begin{array}{l}\text { Muito importante no âmbito interestadual, ligando ao Rio } \\
\text { de Janeiro, ao sul, e Bahia ao norte; interligando-se também } \\
\text { ao eixo centro-leste (BR-262, BR-482 e BR-259) }\end{array}$ \\
\hline BR-259 & $\begin{array}{c}\text { João Neiva, Colatina e Baixo Guandú } \\
\text { BR-262 }\end{array}$ & $\begin{array}{l}\text { Domingos Martins, Marechal Floriano, Venda Nova } \\
\text { do Imigrante, Conceição do Castelo, Muniz Freire, } \\
\text { (centro-oeste) e Minas Gerais }\end{array}$ \\
\hline BR-482 & $\begin{array}{l}\text { Liga Viana, na Microrregião de Vitória, a Iúna e Minas } \\
\text { Gerais }\end{array}$ \\
\hline ES-010 & Serra, Fundão, Aracruz e Conceição da Barra & Liga Itapemirim (sudeste) a Dores do Rio Preto (sudoeste) \\
\hline ES-080 & $\begin{array}{l}\text { Santa Leopoldina, Santa Teresa, Colatina, São } \\
\text { Domingos do Norte e Águia Branca }\end{array}$ & $\begin{array}{l}\text { Liga Cariacica, na Microrregião de Vitória, a Água Doce do } \\
\text { Norte, Noroeste do Estado }\end{array}$ \\
\hline ES-130 & Nova Venécia, São Mateus e Pinheiros & $\begin{array}{l}\text { Importante no eixo norte-sul da Região norte do Estado, } \\
\text { ligando Nova Venécia a Montanha (ES-137) }\end{array}$ \\
\hline ES-137 & $\begin{array}{l}\text { Colatina, São Domingos do Norte, São Gabriel da } \\
\text { Palha, Nova Venécia e Pinheiros }\end{array}$ & $\begin{array}{l}\text { Liga Colatina, Região Central do Estado a Mucurici (norte) } \\
\text { e Bahia }\end{array}$ \\
\hline ES-166 & $\begin{array}{l}\text { Castelo e Venda Nova do Imigrante } \\
\text { ES-320 }\end{array}$ & $\begin{array}{l}\text { Importante no eixo norte-sul da Região Sul do Estado, } \\
\text { ligando Cachoeiro do Itapemirim a Venda Nova do } \\
\text { Imigrante }\end{array}$ \\
\hline \hline
\end{tabular}

* Somente municípios da área de influência do Programa de Fomento 
- Transporte Ferroviário - As duas ferrovias principais que tem influência na área do fomento são: EFVM (Estrada de Ferro Vitória - Minas) com $239 \mathrm{~km}$ no Estado que interliga os portos existentes no Espírito Santo com a Região Centro-Oeste e Sudeste do País; e a FCA (Ferrovia CentroAtlântica) com extensão de $283 \mathrm{~km}$ no Estado que interliga a Região Sul e Sudeste do Brasil ao Espírito Santo;

- Transporte Marítimo - merece destaque o Porto Privado de Barra do Riacho (PORTOCEL), operado pelas empresas Aracruz Celulose e CENIBRA. Atualmente, apenas o terminal especializado de Barra do Riacho está em operação, movimentando cerca de 1,8 milhões de toneladas por ano entre celulose, madeira e sal. A previsão de investimento em sua área nos próximos anos gira entre US\$ 80 e US\$ 120 milhões, necessários para permitir a atracagem de navios de até 65.000 TDW e calado de 46 pés.

- Transporte Aeroviário - existem vários aeroportos de pequeno porte, merecendo destaque somente o aeroporto de Linhares, o qual está inserido num projeto de ampliação da infra-estrutura aeroportuária do Estado, onde são previstos grandes investimentos nos próximos anos.

\subsubsection{2 - Energia}

A capacidade de suprimento de energia elétrica para o Estado é da ordem de $953 \mathrm{MW}$, sendo o parque gerador de energia elétrica bastante limitado, pois apenas $21 \%$ da demanda é suprida pelo próprio Estado. Os $79 \%$ restantes são ofertados pelas usinas hidrelétricas ITAIPÚ e FURNAS.

O segmento industrial é responsável por quase a metade do consumo total de energia elétrica no Estado, seguido pelos segmentos residencial e comercial. Aproximadamente $90 \%$ deste consumo é atendido pela ESCELSA (Espírito Santo Centrais Elétricas S.A.).

Vale ressaltar que das principais usinas hidrelétricas existentes no Estado, 8 (Mascarenhas, Suíça, Rio Bonito, Jucu, Fruteiras,
Alegre, Iúna e Muniz Freire) estão na área de influência do Programa de Fomento, sendo responsáveis por $99,4 \%$ da capacidade de suprimento de energia do parque gerador do Estado.

\subsubsection{3 - Saneamento (Água e Esgoto)}

A CESAN (Companhia EspíritoSantense de Saneamento), controlada pelo Governo Estadual, é responsável pelo saneamento básico e pelo fornecimento de água tratada para uso residencial e industrial para toda a Grande Vitória (5 municípios) e para 64\% dos municípios do interior do Estado. Em 1994, a população atendida com água tratada correspondia a aproximadamente $66 \%$ da população total do Estado. Em se tratando de esgoto sanitário, apenas $12 \%$ da população era atendida.

Do total da população atendida pela CESAN, 1.062 .512 habitantes (59\%) estão sediados na Grande Vitória (Municípios de Cariacica, Serra, Viana, Vila Velha e Vitória). Destes somente o Município de Serra participa da área de influência do Programa de Fomento, onde a população atendida pela CESAN é de 250.125 habitantes.

As zonas urbanas da maioria dos municípios sob a influência do programa em questão, possuem saneamento básico. Entretanto, na zona rural, quase sempre o abastecimento de água é realizado através da captação direta em rios, riachos, córregos, nascentes ou poços artesianos, não apresentando nenhum tipo de tratamento e, o esgoto gerado, normalmente ficando exposto ou liberado diretamente nos cursos d'água, sem a utilização de fossas sépticas.

\subsubsection{4 - Habitação}

O Espírito Santo possui 727.591 unidades domiciliares (IBGE, 1996), das quais cerca de $80 \%$ encontram-se na zona urbana. Estas apresentam uma média de 3,85 pessoas por domicílio enquanto que na zona rural a média é de 3,28 habitantes por unidade domiciliar. Esses números mostram que a média, tanto urbana como rural, é bastante próxima, não apresentando diferença significativa. $\mathrm{O}$ número de domicílios improvisados ou coletivos, ocupados pela população, não chegam a representar 1\% do total do Estado (IBGE, 1996).

A zona urbana da área de influência do Programa de Fomento possui um total de 
228.276 domicílios entre particulares e coletivos, apresentando uma média 3,89 pessoas por domicílio particular, valor muito próximo da média estadual de 3,85 . Já a zona rural apresenta média de 4,23 pessoas por domicílio particular, que é ligeiramente superior à média observada na zona urbana $(3,89)$, mas com uma variação relativamente alta em relação à média estadual $(3,28)$ para a zona rural, variando aproximadamente um indivíduo a mais por domicílio.

\subsubsection{5 - Saúde}

Segundo dados de 1991, a rede física de saúde do Espírito Santo era constituída por 144 hospitais, 489 clínicas e ambulatórios, 565 postos médicos (considerados os postos e centros de saúde), e um total de 7.096 leitos hospitalares. Sendo que os municípios que apresentaram o maior número de leitos por habitante são Cachoeiro de Itapemirim, Colatina e Vitória, todos acima da média estadual (2,7 leitos por 1.000 habitantes).

Complementando a estrutura de saúde do Espírito Santo, alguns dos municípios com sistema de saúde deficitário, dispõem de ambulâncias para transporte de pacientes para hospitais da Grande Vitória.
A população do Espírito Santo apresenta esperança média de vida ao nascer de 71,4 anos, que é superior à da Região Sudeste (68,8 anos) e do Brasil (66,3 anos). A população por médico é de 602 habitantes, situação melhor que a observada para a totalidade do País (641 habitantes/médico), mas deficitária em relação à Região Sudeste (474 habitantes/médico) (SEBRAE, 1999).

A área de influência do Programa de Fomento, em 1991, contava com uma rede física de saúde constituída de 70 hospitais, 84 clínicas e ambulatórios, 375 postos médicos (considerados os postos e centros de saúde), e um total de 4.138 leitos hospitalares. A mesma área apresentava, em 1991, relação geral de 2,88 leitos por mil habitantes.

\subsubsection{6 - Educação}

A rede física de ensino do Estado é composta por 5.932 estabelecimentos (grande parte na zona urbana), atendendo a todos os níveis de ensino e contando com 777.288 alunos matriculados. Na figura 9 é apresentada a porcentagem de alunos matriculados segundo o nível de ensino.

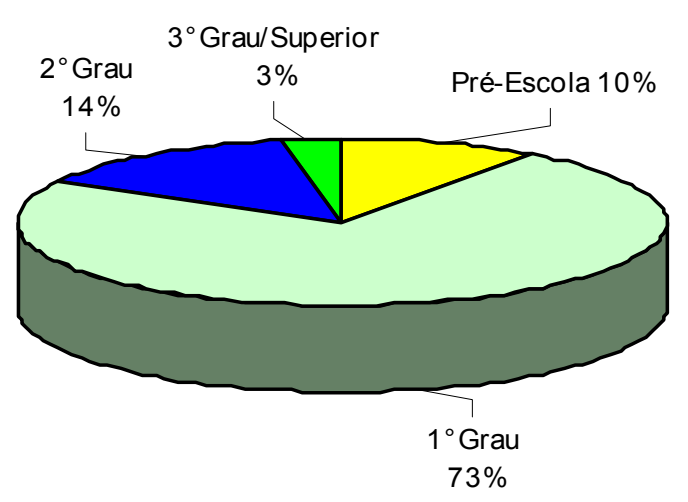

Figura 9: Alunos Matriculados no Estado por Nível de Ensino

Fonte: IBGE, 1996.

Dentre as instituições de ensino destacam-se: no ensino técnico de $2^{\circ}$ grau a Escola Técnica Federal do Espírito Santo (ETFES), as Escolas Agrotécnica Federal de Alegre, de Colatina e a Escola Agrotécnica de Santa Teresa; no ensino de $3^{\circ}$ Grau (Superior) a UFES (Universidade Federal do Espírito Santo), que oferece 34 cursos de graduação e outros diversos de mestrado e especialização; as de treinamento e capacitação profissional como o SENAI (Serviço Nacional de Aprendizagem Industrial) e o SENAC (Serviço Nacional de Aprendizagem Comercial) que oferecem cursos para empregados dos setores da indústria, comércio e serviços, em 5 núcleos instalados nos principais municípios do Estado; e, o SEBRAE (Serviço de Apoio às Micro e Pequenas Empresas), atuando na capacitação gerencial, 
tecnológica e mercadológica de empresários e empregados de micro e pequenas empresas.

Segundo dados de 1996, a área de influência do Programa de Fomento possui 22,6\% da população acima de 4 anos de idade freqüentando escola, totalizando aproximadamente 371 mil pessoas. Este total representa cerca de $48 \%$ dos alunos matriculados em todo o Estado, ou seja, quase metade da população matriculada concentra-se na área de influência do Programa de Fomento da Aracruz.

\subsubsection{7 - Comunicação}

A comunicação por telefonia no Estado opera pelo sistema DDD, DDI e pela telefonia celular. Dados de 1994 indicavam, no Estado, a existência de aproximadamente 300.000 terminais telefônicos, predominando os analógicos.

Além disso, o Estado, através de estações retransmissoras via satélite, recebe imagens televisivas de redes de televisão do Brasil e do exterior. O uso de antenas parabólicas para captação de imagens de televisão é relativamente difundido, principalmente no interior do Estado.

Quanto à radiofonia observa-se uma lacuna a ser desenvolvida, tendo em vista que as emissoras ali instaladas têm um nível de abrangência local, pois poucas são as emissoras que operam via satélite.

\subsection{3 - Economia Regional}

Até os anos 60 o PIB (Produto Interno Bruto) do Estado foi sustentado pelo setor agrícola, principalmente o café, chegando este a responder por $54 \%$ do total do Estado. Com a implantação no Estado de grandes projetos como a ARACRUZ, CVRD, CST e SAMARCO, entre os anos de 1960 e 1967 a base econômica sofreu uma diversificação, fazendo com que nos anos 90 o setor de serviços passasse a atuar como âncora da economia do Estado, impulsionado principalmente pela forte vocação do comércio exterior.

O Estado é considerado o sexto exportador e o quarto maior importador, o que lhe confere cerca de $10 \%$ da receita cambial do País. Somente no ano de 1997, as exportações totalizaram US\$ 5,4 bilhões e as importações US\$ 4,7 bilhões. (SEBRAE, 1998).

O PIB do Estado, em 1996, foi da ordem US\$ 15,8 bilhões, que quando comparado com o PIB total da Região Sudeste representa aproximadamente $3,5 \%$. Além disso, ainda em 1996, o Estado contribuiu com 2,2\% para a formação do PIB nacional. Vale ressaltar que, nos últimos 10 anos, a taxa de crescimento média do PIB vem se mostrando superior à média nacional sendo que, em 1996, o crescimento do PIB do Espírito Santo foi de $6,5 \%$ em relação ao ano anterior (superior ao crescimento do País no mesmo período de 2,9\%).

\subsubsection{1 - Setor Primário}

A análise do setor primário, enfocando a economia regional capixaba, contempla a agricultura, a pecuária, o extrativismo vegetal e a silvicultura. Estima-se que o PIB total deste setor atingiu em 1996 aproximadamente US\$ 3 bilhões, representando $19 \%$ do PIB total do Estado, enquanto que o PIB nacional do setor primário corresponde a $12 \%$ do PIB total do País.

O Estado do Espírito Santo é o primeiro produtor e exportador mundial de celulose branqueada de fibra curta, representado pela Aracruz Celulose S.A.

- Agricultura: a principal cultura agrícola do Estado é o café, ostentando a posição de $2^{\circ}$ maior produtor nacional de café, respondendo por mais de $20 \%$ da produção total do País. Outra cultura de destaque é a fruticultura, sendo o Estado responsável por mais de $35 \%$ da produção nacional de mamão contribuindo com $90 \%$ do total das exportações nacionais do produto.

No que diz respeito à área de influência do Programa de Fomento, os produtos agrícolas mais expressivos são: café e cana-de-açúcar, mas alguns produtos também merecem destaque, entre eles, o milho, o feijão, o abacaxi e o mamão.

- Pecuária: está distribuída praticamente em toda a extensão territorial do Estado, sendo pouco expressiva dentro do contexto nacional. Expressivo incremento ocorreu no efetivo de galináceos devido à expansão do mercado, núcleos urbanos do Estado, que absorvem também grande parte da produção de ovos.

$\mathrm{Na}$ área de influência do Programa de Fomento, destacam-se os rebanhos bovinos das Microrregiões de Linhares, São Mateus, Alegre, Colatina e Nova Venécia, tendo o rebanho bovino 
expressiva participação na pecuária dos Municípios de Afonso Cláudio e Santa Teresa, enquanto que o eqüino destaca-se nas Microrregiões de Linhares e Colatina.

- Extrativismo Vegetal: vinculado à extração de produtos oriundos de florestas nativas, e é pouco expressivo no cenário nacional. Uma forte característica da extração vegetal no Estado é a diminuição dos volumes de toras/toretes produzidos a partir de florestas nativas, para fins de processamento industrial, pois o suprimento pelas florestas plantadas vem aumentando e, há muito tempo, tem sido superior ao das florestas nativas. Quanto à madeira oriunda de florestas nativas, destinada à produção de lenha, verifica-se que o volume extraído tem se mantido constante nesta década.

$\mathrm{Na}$ área de influência do Programa de Fomento, destacam-se o carvão vegetal e a lenha, provenientes das florestas nativas. Destacam-se ainda: a produção de carvão de Linhares e a produção de lenha em Santa Teresa e Afonso Cláudio.

- Silvicultura: é uma importante atividade dentro da economia do Estado. A silvicultura vem se apresentando nos últimos anos como uma cultura alternativa, principalmente para pequenos produtores rurais. Nesse âmbito, iniciativas vem se destacando, a exemplo do Programa de Extensão Florestal da EMATER/ITCF, que no período de 1986 a 1993 reflorestou cerca de 17.000 ha no Estado. Também a Aracruz Celulose S.A. tem incentivado a atividade através do Programa de Fomento Florestal, o qual responde por uma área de aproximadamente 16.000 ha. No último ano, estima-se que tenham sido removidos cerca de 5,5 milhões de $\mathrm{m}^{3}$ de madeira em tora no Espírito Santo, sendo $97 \%$ destinados à produção de celulose, $\mathrm{e}$ os $3 \%$ restantes, direcionados para a produção de carvão vegetal e madeira serrada.

$\mathrm{Na}$ área de influência do Programa de Fomento, a silvicultura é realizada principalmente para a obtenção de matéria-prima para a produção de papel e celulose e carvão vegetal, além da obtenção de madeira em toras para desdobro e de madeira para lenha. Segundo o IBGE (1996), a área do Programa é responsável por uma produção de madeira para papel da ordem de 4,6 milhões de metros cúbicos, com destaque para as Microrregiões de São Mateus e Linhares (77\% do montante plantado de 160,26 milhões de árvores Eucalyptus).

\subsubsection{2 - Setor Secundário}

$\mathrm{O}$ setor secundário é representado basicamente pelo parque industrial do Estado, onde se destacam empresas ligadas à siderurgia e celulose, além de um moderno parque de extração e beneficiamento de rochas ornamentais (mármore e granito). Em 1996, o PIB do setor secundário atingiu US\$ 4,8 bilhões, correspondendo a $30,5 \%$ do PIB total estadual. Esta participação foi bastante similar à média nacional neste mesmo ano (32\%).

A indústria de celulose do Estado é representada por uma única empresa, a Aracruz Celulose S.A (localizada na Microrregião de Linhares, área de influência do Programa de Fomento). A Aracruz produz anualmente cerca de 1,1 milhões de toneladas de celulose, tornando o Estado responsável por $25 \%$ da produção nacional de celulose de fibra curta e por $22 \%$ do mercado mundial.

\subsubsection{3 - Setor Terciário}

O setor terciário engloba as atividades econômicas ligadas ao comércio, transporte e comunicações, instituições financeiras, administrações públicas, aluguéis e outros serviços. O PIB desse setor terciário do Estado atingiu, em 1996, aproximadamente US\$ 8 bilhões, sendo responsável por 50,5\% do PIB do Estado. Esta participação foi inferior a média nacional nesse mesmo ano (56,8\%).

Apesar da participação do PIB do setor terciário capixaba ser inferior a participação desse mesmo setor para o Brasil, o PIB per capita do setor terciário do Espírito Santo apresenta-se desde de 1990 superior à média nacional, acentuando-se esta diferença a partir de 1995.

Apesar de não apresentar parcela significativa no crescimento do setor terciário do Estado, o Programa de Fomento tem atuado como ferramenta importante no fortalecimento do segmento de transportes, principalmente no 
que se refere à movimentação de toras de Eucalyptus, uma vez que os produtores participantes utilizam as pequenas empresas de transportes ou autônomos da Região, gerando uma nova fonte de renda e permitindo a continuidade deste segmento, bastante prejudicado com a queda no cultivo do café e a seca prolongada dos últimos 3 anos.

\subsection{4 - Geração de Empregos e Renda}

\subsubsection{1 - Situação do Emprego}

No quadro 13 são apresentados os índices mensais de emprego no Estado, por ramo de atividade econômica. A partir do quadro 13 pode-se observar que, no ano de 1998, até outubro, considerando-se o total das atividades econômicas, não houve índice de emprego superior a 99,63\% (janeiro) no Estado do Espírito Santo, tendo-se como base valores de dezembro de 1997. A maior queda no mês de outubro foi observada no ramo de Agricultura, Silvicultura, etc., onde o índice caiu de 117,99 (setembro) para 101,19 (outubro).

No que diz respeito à área de Influência do Programa de Fomento a população economicamente ativa representava em 1996, 1.215 .685 pessoas, cerca de $68 \%$ do total do Estado.

Quadro 13: Índice Mensal do Emprego no Estado Segundo Atividade Econômica (1998)

\begin{tabular}{|c|c|c|c|c|c|c|c|c|c|c|}
\hline \multirow{2}{*}{$\begin{array}{c}\text { RAMO DA ATIVIDADE } \\
\text { ECONÔMICA }\end{array}$} & \multicolumn{10}{|c|}{ Mês } \\
\hline & Jan & Fev & Mar & Abr & Mai & Jun & Jul & Ago & Set & Out \\
\hline Todas as Atividades & 99,63 & 99,31 & 98,86 & 99,02 & 99,52 & 99,40 & 99,57 & 99,46 & 98,93 & 98,36 \\
\hline Serv. Ind. Util. Publ. & 100,79 & 100,60 & 100,25 & 99,21 & 97,51 & 96,67 & 96,68 & 96,92 & 95,78 & 95,72 \\
\hline Extrativa Mineral & 99,77 & 100,91 & 100,74 & 101,31 & 100,58 & 99,47 & 99,25 & 99,19 & 98,70 & 99,05 \\
\hline Ind. Transformação & 99,35 & 98,46 & 98,48 & 98,52 & 98,52 & 98,76 & 98,91 & 99,00 & 98,62 & 98,51 \\
\hline Construção Civil & 100,18 & 98,54 & 96,83 & 97,44 & 96,78 & 95,88 & 94,60 & 95,09 & 94,27 & 93,09 \\
\hline Comércio & 99,72 & 99,58 & 98,62 & 98,33 & 98,64 & 98,51 & 98,68 & 98,77 & 98,74 & 98,61 \\
\hline Serviços & 99,41 & 99,38 & 99,12 & 99,46 & 99,64 & 99,41 & 99,11 & 98,98 & 98,82 & 98,54 \\
\hline Adm. Pública & 99,84 & 99,74 & 100,70 & 100,86 & 101,31 & 100,56 & 101,98 & 101,82 & 101,87 & 101,71 \\
\hline Agricult., Silv., etc. & 100,80 & 100,41 & 99,99 & 100,86 & 110,38 & 112,26 & 117,99 & 115,23 & 108,41 & 101,19 \\
\hline Outras & 98,71 & 98,45 & 97,12 & 97,12 & 96,81 & 98,12 & 97,63 & 95,24 & 94,73 & 93,74 \\
\hline
\end{tabular}

Base: Dez. $1997=100,0$

Fonte: CAGED (Cadastro Geral de Empregados e Desempregados), 1998. Lei 4923 / 65

\subsubsection{2 - Estrutura de Salário}

A renda média dos chefes de domicílio na área de influência do Programa de Fomento é, segundo dados do IBGE de 1991, de 2,1 salários mínimos, menor que a média do Estado, que corresponde a 2,9 salários mínimos.

Porém, somente a Aracruz Celulose S.A. pagou no ano de 1997 , o equivalente a 65,25 milhões de reais em salários para os seus funcionários. Em média, considerados seus 2.251 empregados, os salários representaram uma renda de aproximadamente 2.400 reais/mês para cada indivíduo, o que gerou um pagamento de 51,21 milhões de reais em encargos sociais no ano (BRACELPA, 1997).

Deve-se ainda considerar o investimento realizado pela Aracruz Celulose S.A. no Programa de Fomento para o ano de 1998, da ordem de 13,7 milhões de dólares, tanto para a realização de novos contratos, como para a manutenção dos realizados e a compra da madeira disponibilizada, que trouxe um aumento na renda dos chefes de domicílios particulares que participam do programa, como também daqueles que participam indiretamente dos recursos, como os caminhoneiros que transportam a madeira, e a mão-de-obra contratada para as operações de implantação, manutenção e colheita da madeira.

\subsection{5 - Geração de Impostos}

Segundo BORGES \& VILLELA (org.), 1997, os itens de maior peso na receita municipal são o Fundo de Participação dos Municípios FPM, a Quota-Parte Municipal do ICMS - QPMICMS e o conjunto das receitas tributárias próprias. Juntas, essas fontes de recursos representam cerca de $81 \%$ do total da receita para os municípios do Estado. Sozinhos, o FPM 
e a QPM-ICMS representam a maior parte da receita total, cerca de $62 \%$.

De acordo com BORGES \& VILLELA (1997), a receita tributária própria dos municípios tem apresentado excelente desempenho nos últimos anos (1994-1996).
Desde 1994 vêm sendo registrados aumentos na arrecadação, inclusive em 1996, ano de final de mandato nas administrações municipais, quando geralmente diminui o esforço de arrecadação, em função das eleições (quadro 14).

Quadro 14: Evolução da Receita do Estado Segundo Seus Principais Componentes (em mil reais, de maio de 1997)

\begin{tabular}{|l|c|c|c|c|c|c|}
\hline \hline & $\mathbf{1 9 9 1}$ & $\mathbf{1 9 9 2}$ & $\mathbf{1 9 9 3}$ & $\mathbf{1 9 9 4}$ & $\mathbf{1 9 9 5}$ & $\mathbf{1 9 9 6}$ \\
\hline \hline Receita Própria Total & $115.479,2$ & $104.990,8$ & $93.263,7$ & $114.546,0$ & $154.668,7$ & $163.300,6$ \\
\hline IPTU & $16.955,8$ & $9.033,6$ & $8.250,7$ & $10.937,0$ & $26.443,5$ & $24.464,7$ \\
\hline ISS & $61.681,6$ & $58.345,5$ & $45.781,2$ & $58.989,1$ & $74.337,7$ & $81.692,0$ \\
\hline ITBI & $8.305,0$ & $6.611,8$ & $12.020,6$ & $9.708,8$ & $11.747,5$ & $11.776,3$ \\
\hline Taxas & $20.346,7$ & $23.004,5$ & $19.111,2$ & $26.700,7$ & $35.274,9$ & $45.912,4$ \\
\hline QPM-ICMS & n.d. & 221.100 & 199.200 & 261.100 & 383.500 & 368.100 \\
\hline Receita Total & $\mathbf{6 4 4 . 8 9 6 , 2}$ & $\mathbf{5 7 8 . 1 5 3 , 8}$ & $\mathbf{6 3 7 . 3 5 8 , 4}$ & $\mathbf{6 9 0 . 2 8 7 , 2}$ & $\mathbf{8 5 6 . 1 5 4 , 4}$ & $\mathbf{8 4 3 . 1 0 7 , 8}$ \\
\hline \hline
\end{tabular}

Fonte: BORGES \& VILLELA (1997)

O FPM (Fundo de Participação dos Municípios) da área de influência do Programa de Fomento representa cerca de $22 \%$ da receita total dessa área. No quadro 15 são apresentadas as informações referentes à geração de impostos na área de influência do Programa.

Quadro 15: Receita no Ano de 1996 da Área de Influência (AI) do Programa, Segundo Seus Principais Componentes e as Microrregiões (Em Reais de Maio de 1997)

\begin{tabular}{|c|c|c|c|c|c|c|c|c|c|}
\hline \multirow{2}{*}{ MICRORREGIÃO } & \multirow{2}{*}{$\begin{array}{l}\text { RECEITA } \\
\text { PRÓPRIA }\end{array}$} & \multirow{2}{*}{ IPTU } & \multirow{2}{*}{ ISS } & \multirow{2}{*}{ ITBI } & \multirow{2}{*}{ TAXAS } & \multirow{2}{*}{ FPM } & \multirow{2}{*}{$\begin{array}{l}\text { QPM- } \\
\text { ICMS }\end{array}$} & \multicolumn{2}{|c|}{ RECEITA TOTAL } \\
\hline & & & & & & & & R\$ (mai-97) & $\%$ da $\mathrm{AI}$ \\
\hline Afonso Cláudio ${ }^{(1)}$ & 1.974 .981 & 303.462 & 426.928 & 250.924 & 967.982 & 8.015 .371 & 13.726 .346 & 29.298 .546 & 7,7 \\
\hline Guarapari & 206.700 & 34.481 & 22.356 & 39.742 & 109.407 & 1.409 .075 & 1.709 .450 & 4.392 .006 & 1,2 \\
\hline Santa Teresa ${ }^{(2)}$ & 887.491 & 151.677 & 193.067 & 149.057 & 386.240 & 7.649 .416 & 13.436 .176 & 24.357 .284 & 6,5 \\
\hline Vitória (Serra) & 17.423 .703 & 3.378 .768 & 8.896 .500 & 661.870 & 4.447 .689 & 8.886 .057 & 50.521 .770 & 87.459 .900 & 23,2 \\
\hline Linhares $^{(3) \mathrm{e}(4)}$ & 9.097 .191 & 1.000 .330 & 4.395 .953 & 647.661 & 3.032 .408 & 11.886 .930 & 44.925 .811 & 82.985 .944 & 22,0 \\
\hline Montanha (Pinheiros) & 358.546 & 30.994 & 41.669 & 26.499 & 258.195 & 1.043 .053 & 55.440 & 4.606 .149 & 1,2 \\
\hline São Mateus ${ }^{(4)}$ & 2.644 .438 & 432.638 & 1.265 .712 & 249.199 & 1.747 .037 & 6.369 .515 & 12.218 .447 & 28.954 .326 & 7,7 \\
\hline Barra de São Francisco & 121.311 & 15.038 & 1.971 & 31.190 & 72.545 & 1.788 .090 & 1.301 .228 & 3.790 .722 & 1,0 \\
\hline Colatina $^{(4) \mathrm{e}(5)}$ & 3.549 .530 & 587.632 & 1.787 .350 & 269.320 & 921.737 & 12.333 .500 & 23.986.201 & 49.283 .567 & 13,1 \\
\hline Nova Venécia ${ }^{(6)}$ & 1.136 .904 & 205.424 & 262.866 & 132.213 & 448.286 & 7.378 .708 & 12.099 .009 & 26.224 .792 & 7,0 \\
\hline Alegre (Exceto Guaçuí) & 1.604 .045 & 295.178 & 366.249 & 227.616 & 252.082 & 12.047 .355 & 11.725 .809 & 25.961 .727 & 6,9 \\
\hline Cachoeiro de Itapemirim $^{(7)}$ & 633.168 & 243.594 & 173.158 & 74.902 & 133.622 & 3.576 .450 & 4.685 .739 & 9.430 .385 & 2,5 \\
\hline Total & 39.638 .008 & 6.679 .216 & 17.833.779 & 2.760 .193 & 12.777 .230 & 82.383.520 & 190.391 .426 & 376.745 .348 & 100,0 \\
\hline$\%$ receita total da $\mathrm{AI}$ & 10,5 & 1,8 & 4,7 & 0,7 & 3,4 & 21,9 & 50,5 & & - \\
\hline$\%$ do Estado & 24,3 & 27,3 & 21,8 & 23,5 & 27,8 & 55,0 & 51,0 & 44,7 & - \\
\hline
\end{tabular}

${ }^{(1)}$ Contempla também Brejetuba.

(2) Contempla também São Roque do Canaã, município que não está na AI, foi criado posteriormente.

(3) Contempla também Sooretama, município recentemente criado, subtraído de Linhares.

(4) Todos os municípios.

(5) Contempla também Governador Lindemberg, município criado recentemente, subtraído de Colatina.

${ }^{(6)}$ Contempla também Vila Valério e Vila Pavão, municípios criados recentemente.

(7) Municípios de Castelo, Vargem Alta.

Fonte: BORGES \& VILLELA (1997) 
Somente a Aracruz Celulose S.A. gerou um recolhimento relativo a impostos e taxas pagos na ordem de 3,84 milhões de reais no ano de 1997, contra 10,89 milhões de reais em 1996. Este recolhimento representou cerca de $0,5 \%$ da receita total arrecadada em 1997. Considerada a previsão de investimento da Aracruz Celulose S.A, no Programa de Fomento Florestal para o ano de 1999, o valor de impostos e taxas a serem gerados será da ordem de 2,8 milhões de reais, representados pelo ICMS, FUNRURAL e Taxas. Somente o ICMS será responsável por um recolhimento de aproximadamente 2,5 milhões de reais.

\section{7 - O PROGRAMA DE FOMENTO FLORESTAL}

\section{1 - Antecedentes}

O Programa de Fomento Florestal implantado pela Aracruz Celulose S.A., na visão dos órgãos públicos, estaria embasado nas seguintes premissas: necessidade de implantação de florestas artificiais de crescimento rápido para suprir as necessidades de consumo de madeira do Estado; atender a uma reivindicação antiga do Governo Estadual de criar a possibilidade da oferta pelo produtor rural de matéria-prima de origem florestal; resgatar a vocação florestal do Estado e promover o recobrimento arbóreo de áreas degradadas improdutivas e com declividades acentuadas.

Para a Aracruz esse programa foi elaborado visando, além de atender os aspectos citados anteriormente, criar alternativas de fornecimento de matéria-prima para a produção de celulose e permitir a desconcentração dos plantios de Eucalyptus, fazendo com que pequenos e médios produtores rurais utilizem áreas ociosas de suas propriedades, obtendo, ao final do ciclo de produção, um aporte de renda adicional na economia familiar.

\section{2 - Objetivos}

\section{- Geral:}

- Estimular a criação de um mercado de madeira regional e desenvolver fontes alternativas para suprir a demanda de madeira para energia e celulose, através de parceria com produtores rurais.

\section{- Específicos:}

- Criação de alternativa de renda para os pequenos e médios proprietários rurais;

- Resgatar a vocação florestal do Estado;

- Contribuir para a desconcentração das florestas homogêneas;

- Permitir a geração de impostos, favorecendo a arrecadação dos municípios envolvidos com o Programa de Fomento;

- Promover a geração de empregos, direta e indiretamente, na região de influência do Programa de Fomento reduzindo o êxodo rural;

- Reduzir a pressão sobre as florestas nativas e permitir a sua preservação, proporcionado, através da oferta de madeira oriunda dos 3\% da produção destinada aos produtores, dos resíduos aproveitáveis da colheita da madeira, e da doação ao produtor prevista em contrato, do equivalente a $3 \%$ do total plantado, em mudas nativas fornecidas para serem plantadas nas propriedades fomentadas;

- Propor o plantio florestal em áreas marginais da propriedade, como as de declividade superior a 30\% (130) e inferior a 100\% (450), degradadas ou improdutivas;

- Promover a educação preservacionista, através dos contatos realizados pelo corpo técnico da Aracruz e cultura proporcionada pela implantação dos florestamentos.

\section{3 - Justificativas}

- Econômicas: o programa, como atividade complementar, proporciona uma boa rentabilidade ao produtor, além de permitir a recuperação de áreas degradadas e suprir as necessidades de madeira da propriedade através do volume previsto em contrato, destinado ao produtor ( $3 \%$ da produção total), sem ônus adicional;

- Sociais: a implantação dos projetos fomentados permitirá, de forma direta, a fixação de parte da mão-de-obra disponível nas áreas de influência do programa, contribuindo expressivamente na redução do êxodo rural capixaba. Além disso, a adoção de novas tecnologias e a assistência técnica fornecida pela Aracruz, 
poderão proporcionar um aumento na conscientização preservacionista da população sob a influência do programa; e,

- Regionais e Geração de Divisas: o Programa de Fomento possibilita ao produtor rural uma cultura alternativa na propriedade gerando uma renda adicional; proporciona a instalação de novas unidades industriais vinculadas ao Setor Florestal; permite a redução na pressão exercida sobre as florestas nativas no
Estado; e, aumentará o recolhimento de ICMS, TAXAS FLORESTAIS e FUNRURAL devido à renda bruta gerada pela venda da madeira à Aracruz, oriunda dos projetos fomentados a partir de 1990.

\section{4 - Caracterização Fundiária das Propriedades}

A estrutura dos estabelecimentos rurais no Estado, que participam do Programa de Fomento, é apresentada no quadro 16.

Quadro 16: Estrutura Fundiária das Propriedades Amostradas no Levantamento de Campo

\begin{tabular}{|c|c|c|c|c|c|c|c|c|c|c|}
\hline \multirow{2}{*}{$\begin{array}{c}\text { GRUPOS DE ÁREA TOTAL } \\
\text { (ha) }\end{array}$} & \multicolumn{10}{|c|}{ NÚMERO DE PROPRIEDADES / ANO } \\
\hline & 1990 & 1991 & 1992 & 1993 & 1994 & 1995 & 1996 & 1997 & 1998 & TOTAL \\
\hline $\begin{array}{l}\text { Menos de } \mathbf{1 0} \\
1 \text { a menos de } 5 \\
5 \text { a menos de } 10\end{array}$ & $\begin{array}{l}1 \\
1 \\
0\end{array}$ & $\begin{array}{c}12 \\
7 \\
5\end{array}$ & $\begin{array}{l}28 \\
17 \\
11\end{array}$ & $\begin{array}{l}28 \\
17 \\
11\end{array}$ & $\begin{array}{l}0 \\
0 \\
0\end{array}$ & $\begin{array}{l}9 \\
6 \\
3\end{array}$ & $\begin{array}{l}2 \\
2 \\
0\end{array}$ & $\begin{array}{l}2 \\
1 \\
1\end{array}$ & $\begin{array}{l}4 \\
3 \\
1\end{array}$ & $\begin{array}{l}86 \\
53 \\
33\end{array}$ \\
\hline $\begin{array}{l}\mathbf{1 0} \text { a menos de } \mathbf{1 0 0} \\
10 \text { a menos de } 20 \\
20 \text { a menos de } 50 \\
50 \text { a menos de } 100\end{array}$ & $\begin{array}{l}0 \\
0 \\
0 \\
0\end{array}$ & $\begin{array}{l}7 \\
3 \\
3 \\
1 \\
\end{array}$ & $\begin{array}{l}7 \\
2 \\
5 \\
0 \\
\end{array}$ & $\begin{array}{l}4 \\
3 \\
1 \\
0 \\
\end{array}$ & $\begin{array}{l}0 \\
0 \\
0 \\
0 \\
\end{array}$ & $\begin{array}{l}1 \\
0 \\
1 \\
0 \\
\end{array}$ & $\begin{array}{l}1 \\
0 \\
1 \\
0\end{array}$ & $\begin{array}{l}2 \\
1 \\
1 \\
0\end{array}$ & $\begin{array}{l}6 \\
4 \\
2 \\
0 \\
\end{array}$ & $\begin{array}{l}28 \\
13 \\
14 \\
01\end{array}$ \\
\hline TOTAL & 1 & 19 & 35 & 32 & $\mathbf{0}$ & 10 & 3 & 4 & 10 & 114 \\
\hline
\end{tabular}

Fonte: Aracruz Celulose S.A. e Levantamento de Campo da STCP

\section{5 - Uso do Solo}

No quadro 17 são apresentadas as principais atividades desenvolvidas nas propriedades participantes do Programa e a cobertura do solo. Vale lembrar que nem todas as atividades citadas no quadro ocorrem concomitantemente em todas as propriedades. Os valores médios apresentados, são apenas indicativos do uso do solo nas propriedades rurais.

Quadro 17: Valores Médios de Uso do Solo nas Propriedades Participantes do Programa, com Base na Amostragem de Campo

\begin{tabular}{|c|c|c|}
\hline ATIVIDADE DESENVOLVIDA & ÁREA (ha) & PERCENTUAL (\%) \\
\hline Reserva Legal & 4,3 & 6,12 \\
\hline Preservação Permanente & 3,7 & 5,26 \\
\hline Eucalyptus & 24,8 & 35,29 \\
\hline Pecuária (pastagem) & 12,2 & 17,35 \\
\hline Suinocultura & n.s. & n.s. \\
\hline Avicultura & n.s. & n.s. \\
\hline Horticultura & 0,6 & 0,85 \\
\hline Arroz & 0,1 & 0,14 \\
\hline Feijão & 0,4 & 0,57 \\
\hline Milho & 0,4 & 0,57 \\
\hline Café & 11,3 & 16,07 \\
\hline Outros* & 12,5 & 17,78 \\
\hline TOTAL & 70,3 & 100,00 \\
\hline
\end{tabular}

n.s. = não significativo

* todas as atividades desenvolvidas nas propriedades que apresentaram áreas físicas não significativas, como a sede, hortas, criações, pomares de subsistência e outras benfeitorias

Fonte: Amostragem de Campo da STCP 


\section{6 - Aspectos Ambientais}

Durante os levantamentos de campo realizados, foram avaliados os aspectos ambientais relativos às propriedades participantes do Programa de Fomento Florestal. Os aspectos avaliados referem-se ao relevo, características edáficas, conservação e preservação, cultura temporária, cultura permanente, pastagem e floresta plantada.

O relevo nas propriedades avaliadas apresenta variações extremas, a altitude varia desde $15 \mathrm{~m}$ até $1.200 \mathrm{~m}$ acima do nível do mar, sendo que a maior parte das propriedades foi enquadrada em terrenos com declividade entre $13^{\circ}$ a $45^{\circ}$.

A classe de solo predominante nas propriedades é o Latossolo, ocorrendo em $89,5 \%$ das áreas levantadas. A variação de maior ocorrência é o Latossolo Vermelho Amarelo com 51,8\%, somados a estes as subvariações álico, distrófico e húmico, ocorrentes em mais de $35 \%$ das propriedades. Cerca de 93\% dos solos que compõem as propriedades são profundos a medianos, com ligeira predominância para o segundo, o que demonstra que o nível de erosão nas áreas onde foram implantados os plantios de Eucalyptus é baixo, tanto que $99 \%$ das propriedades apresentam níveis de erosão entre nulo a laminar, e a fertilidade do solo variando entre boa a regular em $96 \%$ das propriedades.

Em se tratando de conservação e preservação, entre as 114 propriedades selecionadas para a amostragem de campo $(7.309,2$ ha), somente 56 (49\%) possuem Reserva Legal e 67 propriedades (59\%) possuem Áreas de Preservação Permanente. Procurando reverter essa situação, a Aracruz Celulose S.A. tem feito a redução da área plantada do contrato, transformando essa área reduzida em área de Preservação Permanente, sem ônus para o produtor.

Os dados levantados em campo permitiram, também, a análise do uso anterior do solo nas propriedades (culturas temporárias e permanente). Os dados demonstraram que $27 \%$ das propriedades tinham suas áreas utilizadas anteriormente por pelo menos um tipo de cultura temporária com fins comerciais, sendo as culturas mais difundidas, o feijão e o milho. Já a utilização anterior para culturas permanentes foi evidenciada em $80 \%$ das propriedades, sendo as culturas mais difundidas o café e a pastagem.

No que diz respeito a florestas plantadas, é importante ressaltar que a Aracruz, através do Programa de Fomento Florestal, considerando pequenas e médias propriedades localizadas dentro de um raio economicamente viável, implantou somente no Estado do Espírito Santo, 17.422,40 ha de florestas de Eucalyptus (Foto 01). A meta, seguindo o determinado pela L.O. (Licença de Operação) emitida pela SEAMA, é de se atingir 28.000 ha no Estado.

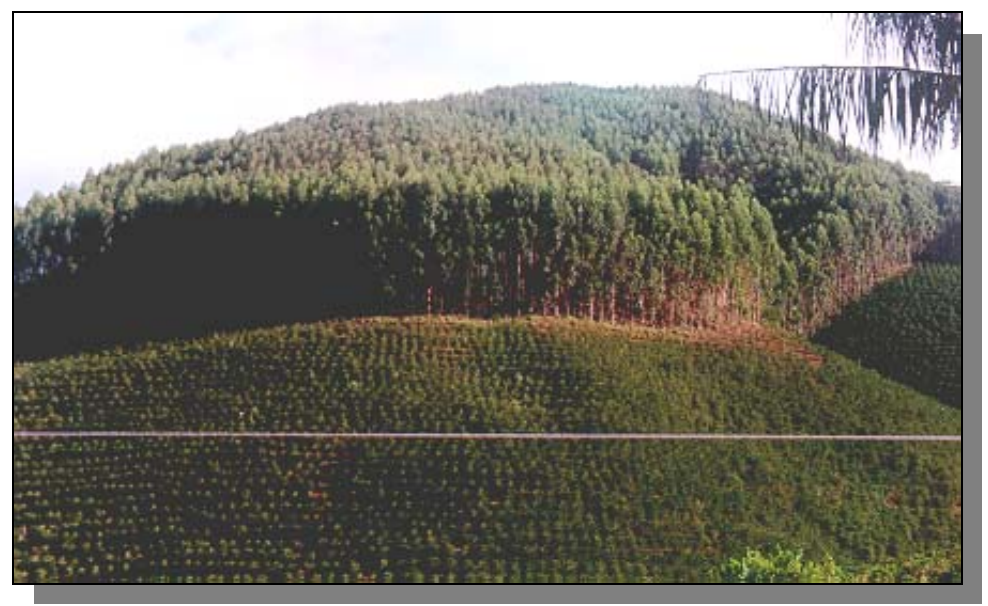

Foto 1: $\quad$ Vista Global de Floresta Nova e Adulta Fomentada 
Outra atividade florestal que recebe apoio da Aracruz, é o Programa de Extensão Florestal do Governo do Estado do Espírito Santo, através do qual foram distribuídas cerca de 49,8 milhões de mudas de Eucalyptus para cerca de 17 mil agricultores, nos 71 municípios do Estado.

\section{7 - Avaliação Socioeconômica Comparativa}

O objetivo desse item foi efetuar a avaliação socioeconômica do Programa de Fomento Florestal da Aracruz, tendo como parâmetro as atividades agropecuárias desenvolvidas na área de influência do programa.

As atividades a serem comparadas correspondem as duas culturas que figuram como alternativas em relação à silvicultura, de acordo com suas performances econômicas e de participação no uso do solo do Estado, a cafeicultura e a pecuária, respectivamente, $16 \%$ e $64 \%$ da área explorada economicamente no Estado.

Estudos realizados no ano de 1995 , sobre a competitividade econômica do eucalipto, COSTA (1996) já apontavam nítida vantagem do eucalipto frente à cafeicultura e à pecuária, confirmando a potencialidade do eucalipto como cultura preferencial na geração de renda líquida da terra.

A partir das análises realizadas foi elaborado o quadro 18, que possibilitou as seguintes conclusões:

Quadro 18: Sinopse dos Resultados a Preços Médios da Série de 1991 a 1997

\begin{tabular}{|c|c|c|c|c|c|c|c|c|c|c|c|}
\hline \multirow{3}{*}{ Discriminação } & \multicolumn{11}{|c|}{ Atividades } \\
\hline & \multirow{2}{*}{\begin{tabular}{|c|} 
Eucalipto \\
$30,43 \mathrm{~m}^{3} / \mathrm{ha}$ \\
\end{tabular}} & \multicolumn{3}{|c|}{ Café Arábica } & \multicolumn{3}{|c|}{ Café Conilon } & \multicolumn{2}{|c|}{ Pecuária de Leite } & \multicolumn{2}{|c|}{$\begin{array}{l}\text { Pecuária de } \\
\text { Corte }\end{array}$} \\
\hline & & $4 \mathrm{sc} / \mathrm{ha}$ & $8 \mathrm{sc} / \mathrm{ha}$ & $12 \mathrm{sc} / \mathrm{ha}$ & $4 \mathrm{sc} / \mathrm{ha}$ & $8 \mathrm{sc} / \mathrm{ha}$ & $12 \mathrm{se} / \mathrm{ha}$ & $41 /$ vaca & $10 \mathrm{l} / \mathrm{vaca}$ & $\begin{array}{l}3,67 @ \\
+ \text { leite }\end{array}$ & 4,43@ \\
\hline 1. Custos Totais ( $\mathrm{R} \$ / \mathrm{ha} / \mathrm{ano})$ & 312,01 & 707,45 & 890,31 & 1123,20 & 596,10 & 745,61 & 923,83 & 157,13 & 536,16 & 136,91 & 110,55 \\
\hline $\begin{array}{l}\text { 2. Custo Total Café ou Pecuária / } \\
\text { Custo Eucalipto }\end{array}$ & 1,00 & 2,27 & 2,85 & 3,60 & 1,91 & 2,39 & 2,96 & 0,50 & 1,72 & 0,44 & 0,35 \\
\hline 3. Receita Bruta (R $\$ /$ ha/ano) & 354,03 & 343,10 & 686,19 & 1029,29 & 286,90 & 573,80 & 860,69 & 105,64 & 498,04 & 113,63 & 91,45 \\
\hline $\begin{array}{l}\text { 4. Receita Bruta do Café ou } \\
\text { Pecuária /Receita Bruta do } \\
\text { Eucalipto (R\$/ha/ano) }\end{array}$ & 1,00 & 0,97 & 1,94 & 2,91 & 0,81 & 1,62 & 2,43 & 0,30 & 1,41 & 0,32 & 0,26 \\
\hline 5. Receita Bruta / Custos Totais & 1,13 & 0,48 & 0,77 & 0,92 & 0,48 & 0,77 & 0,93 & 0,67 & 0,93 & 0,83 & 0,83 \\
\hline 6. Receita Líquida (R\$/ha/ano) & 42,02 & $(364,35)$ & $(204,12)$ & $(93,91)$ & $(309,20)$ & $(171,81)$ & $(63,13)$ & $(51,49)$ & $(38,11)$ & $(23,28)$ & $(19,10)$ \\
\hline $\begin{array}{l}\text { 7. Receita Líquida / Custos Totais } \\
(\%)\end{array}$ & 0,13 & $(0,52)$ & $(0,23)$ & $(0,08)$ & $(0,52)$ & $(0,23)$ & $(0,07)$ & $(0,33)$ & $(0,07)$ & $(0,17)$ & $(0,17)$ \\
\hline $\begin{array}{l}\text { 8. Receita Líquida Café ou } \\
\text { Pecuária / Receita Líquida } \\
\text { Eucalipto }\end{array}$ & 1,00 & $(8,67)$ & $(4,86)$ & $(2,24)$ & $(7,36)$ & $(4,09)$ & $(1,50)$ & $(1,23)$ & $(0,91)$ & $(0,55)$ & $(0,45)$ \\
\hline $\begin{array}{l}\text { 9. Probabilidade de Ocorrência dos } \\
\text { Preços de Equilíbrio (\%) }\end{array}$ & 50,00 & 0,43 & 21,34 & 38,49 & 0,53 & 21,82 & 39,93 & - & 9,47 & 0,00 & 0,00 \\
\hline $\begin{array}{l}\text { 10. Dispersão Relativa dos } \\
\text { Preços }(\%)\end{array}$ & 15,58 & 66,87 & 66,87 & 66,87 & 70,95 & 70,95 & 70,95 & 23,41 & 23,41 & 16,93 & 16,93 \\
\hline
\end{tabular}

Fonte: COSTA, LOSS E BARBOSA (1998)

- Comparativamente com o café, tanto arabica quanto conilon, os custos totais/ha do Eucalyptus são, pelo menos, 1,9 vez inferiores, sendo que, quanto maiores os níveis de produtividade do café, maior a densidade dos custos (mais investimentos e maiores riscos);
- Em relação à pecuária extensiva, tanto de leite (4 litros/vaca/dia), quanto à mista $\mathrm{e}$ de corte, a densidade dos custos é baixa, representando cerca de $50 \%$ ou menos da densidade de custos do Eucalyptus. Contudo, a baixa eficiência técnica destas atividades (produtividade) coloca-as em desvantagem em relação ao Eucalyptus; 
- A Pecuária Leiteira, com produtividade de 10 litros/vaca/dia, considerada semiextensiva, apresenta boa eficiência técnica e elevada densidade de custos. Associada à maior variação dos preços do leite, esta atividade apresenta riscos maiores do que o investimento em Eucalyptus;

- Na Pecuária Leiteira a preços atuais, a relação receita líquida/custos totais é de $-9,01 \%$ (prejuízo) para a produtividade de 10 litros/vaca/dia. Na média histórica dos preços reais, esse índice é de $-7,1 \%$ (prejuízo);

- Na Pecuária Mista e de Corte, a preços atuais, a relação receita líquida/custos totais, é de $-17,45 \%$ (prejuízo), observada na produtividade de 4,43 @/ha/ano. Na média histórica dos preços reais, esse percentual reduz para $-17,0 \%$ (prejuízo);

- O Eucalyptus, considerada a média histórica dos preços, supera em renda líquida o café arábica para qualquer produtividade. A preços atuais, equivalentes a $\mathrm{R} \$ 122,00 / \mathrm{sc}$, a receita líquida do café arábica supera a do Eucalyptus para as produtividades de 8 sc/ha e $12 \mathrm{sc} / \mathrm{ha}$. Contudo, a chance de ocorrer preço igual ou superior a este é de apenas 5,05\%;

- O café conilon, considerada a média histórica de preços, perde em renda líquida para o Eucalyptus, em todas as produtividades consideradas. Computando-se somente os custos variáveis, o Eucalyptus só é superado na produtividade do café de $12 \mathrm{sc} / \mathrm{ha}$. Porém, em relação aos preços atuais, o café conilon supera o Eucalyptus em todos os níveis de produtividade, a exceção de $4 \mathrm{sc} / \mathrm{ha}$, considerando os custos totais; e,

- Em nenhum nível de produtividade considerada, a receita líquida da Pecuária de Corte superou a do Eucalyptus.

Consideradas as afirmativas apresentadas pode-se, de maneira geral, inferir que:
- A insistência dos produtores em cultivar café ou pastagem em áreas de baixo rendimento pode ser explicada pela utilização da mão-de-obra familiar ou meeiros, com baixo custo de oportunidade;

- Os resultados obtidos mostram a necessidade de conscientização dos produtores para a adoção de novas atividades de produção em áreas de baixa produtividade, onde o Eucalyptus se destaca pela nítida vantagem econômica e capacidade competitiva em solos impróprios ao uso mais intenso; e,

- Os cafeicultores e pecuaristas, com produtividades abaixo da média no Estado, estão em franco processo de descapitalização e empobrecimento, podendo criar três situações de efeito desastroso, a saber: ampliação do passivo da mão-de-obra familiar ou de empregos mal remunerados e seus encargos; aumento significativo da depreciação dos bens não contabilizados de sua propriedade, que se consomem; e, processo progressivo de degradação do valor da propriedade (terra) pela falta de uso das técnicas de conservação.

\section{8 - Atividades Florestais do Programa de Fomento}

As atividades florestais do Programa de Fomento englobam as seguintes fases: planejamento, implantação, colheita e continuidade/desativação.

Vale ressaltar que, somente as atividades relativas à produção e/ou fornecimento de mudas, assistência técnica, iscas formicidas e adubos, são de responsabilidade da Aracruz. As atividades restantes referentes ao preparo do terreno, plantio, manutenção, colheita da madeira e transporte cabem aos produtores fomentados.

\subsection{1 - Planejamento}

$\mathrm{Na}$ fase de planejamento estão inseridas as atividades de divulgação, seleção dos produtores interessados em participar do Programa de Fomento e efetivação dos contratos. 
Inicialmente o Programa tinha como meta, até o ano de 1995, o plantio parcelado de 28.000 ha de florestas de Eucalyptus, no Estado. Os plantios deveriam ser executados através da participação de terceiros, por livre adesão, com plantios em áreas de no mínimo 5 ha, procurando atender a uma reivindicação do Governo Estadual de desconcentração dos florestamentos homogêneos e promovendo a participação de pequenos e médios produtores.

No entanto, a ARACRUZ tem realizado plantios em áreas menores que 5 ha, dependendo de análise técnica das condições de produção e aprovação do IDAF (Instituto de Defesa Agropecuária e Florestal do Espírito Santo). Situação esta que viabiliza ainda mais o plantio em propriedades menores, abrindo a possibilidade de participação dos pequenos produtores no programa de fomento.

Os insumos e a assistência técnica são fornecidos pela Aracruz, cabendo ao produtor disponibilizar a terra e contratar ou disponibilizar a mão-de-obra e máquinas/equipamentos necessários para as atividades de implantação da floresta, colheita da madeira e transporte até o depósito da Aracruz estabelecido em contrato. A Aracruz desenvolveu, ainda, manuais técnicos que procuram orientar qual a forma correta de cultivo do Eucalyptus, os cuidados a se tomar para minimizar a ocorrência de acidentes e a forma correta ou técnicas mais eficazes para se efetuar a colheita da madeira.

\section{- Divulgação do Programa de Fomento}

A divulgação é realizada através da distribuição de folhetos explicativos desenvolvidos pela empresa, pelos meios de comunicação do Estado (televisão, rádio, jornais e revistas), através de palestras e reuniões realizadas pelo corpo técnico da Aracruz com associações, cooperativas, Igrejas, etc., e o contato direto com os produtores, com conseqüente cadastramento dos interessados em participar dessa iniciativa.

\section{- Seleção dos Produtores}

É realizada com base na fiscalização da propriedade e aprovação do projeto de plantio pelo IDAF (Instituto de Defesa Agropecuária e Florestal do Espírito Santo). Caso a propriedade atenda às especificações ambientais previstas na legislação vigente e no Programa de Fomento, providencia-se a formulação do contrato, com informações subsidiadas pelo técnico responsável pela região.

\section{- Contratos}

No quadro 19 são apresentadas algumas considerações, tais como: número e tipos de contratos firmados com a Aracruz; e, formas de divulgação do programa.

Quadro 19: Quantidade e Tipos de Contratos Observados

\begin{tabular}{|l|c|c|}
\hline \multicolumn{1}{|c|}{ ITEM } & QUANTIDADE (ud) & PERCENTUAL (\%) \\
\hline \hline Número de Contratos & 229 & - \\
- Total Observado & 2 & - \\
- Média Por Produtor & & 0,00 \\
\hline Tipo de Contrato & 0 & 11,40 \\
- Contrato de Entrega de Mudas & 13 & 88,60 \\
- Contrato de Preferência & 101 & \\
- Contrato de Compra e Venda & & 67,54 \\
\hline Como Soube do Programa (formas de divulgação) & 77 & 10,53 \\
- Aracruz & 12 & 0,88 \\
- EMCAPER & 1 & 16,67 \\
- Igreja & 19 & 4,39 \\
- Vizinhos & 5 & $\mathbf{1 0 0 , 0 0}$ \\
- Outros & $\mathbf{1 1 4}$ & \\
\hline \hline \multicolumn{2}{|c|}{ TOTAL } &
\end{tabular}


Os tipos de contratos disponíveis para os produtores participantes do Programa de Fomento da Aracruz são:

- Contrato de Entregas de Mudas - prevê somente a entrega de mudas e o fornecimento de assistência técnica durante 1 (um) ano;

- Contrato de Compra e Venda - área mínima de 5 ha, o produtor recebe assistência técnica (durante todo o período de vigência do contrato), mudas, insumos e o financiamento das atividades operacionais (implantação, manutenção e colheita) e é obrigado a vender toda a produção para a Aracruz, descontados os $3 \%$ do volume que lhe cabem, conforme cláusulas contratuais. No momento da venda a empresa é ressarcida do financiamento das atividades operacionais, pela conversão em madeira do valor financiado;

- Contrato de Preferência - área de plantio mínima de 3 ha, regula a cessão de insumos e assistência técnica ao produtor por 1 (um) ano, podendo o mutuário escolher o destino da madeira. Se vendê-la a Aracruz, fica isento do ressarcimento à empresa, dos insumos e assistência técnica para a implantação do projeto, caso contrário se paga na época da colheita através da conversão do valor em madeira;

- Contrato de Compra e Venda $2^{\circ}$ Ciclo viabilizado para os produtores interessados na renovação do contrato de venda da madeira e depois de realizada avaliação técnica, por parte da Aracruz, constatando sua viabilidade técnica. Este contrato é diferente do contrato de compra e venda, pois não há necessidade de preparo do terreno nas atividades silviculturais;

- Termo de Preferência $2^{\circ}$ Ciclo - onde se prevê uma área de plantio mínima de 3 ha, regula a cessão de insumos e assistência técnica ao produtor por 1 (um) ano, podendo o mutuário escolher o destino da madeira. Se vendê-la à
Aracruz, fica isento do ressarcimento à empresa, dos insumos e assistência técnica e serviços prestados para a implantação do projeto, caso contrário, se paga na época da colheita através da conversão do valor em madeira; e,

- Aspectos Ambientais nas Propriedades Contratadas - No que tange aos aspectos ambientais referentes à preservação permanente, como cursos d'água, declividade acentuada, nascentes, topos de morros e qualidade da água e solo após o plantio, foram realizadas pesquisas nas propriedades para avaliar cada um desses aspectos. Os resultados dessas pesquisas são apresentados no quadro 20 .

\subsection{2 - Implantação da Floresta}

As atividades incluídas nesta fase correspondem àquelas que compõem as atividades de produção de madeira de Eucalyptus, sendo:

- Preparo do Solo - realizadas para criar condições ideais no estabelecimento e desenvolvimento das mudas na fase inicial. O preparo do solo é caracterizado pelas atividades de limpeza da área e combate à formiga. Para essa fase a Aracruz desenvolveu um folheto explicativo denominado por "Manual do Cultivo do Eucalipto";

- Plantio - é compreendido pelas atividades de alinhamento e marcação das covas, coveamento, adubação, fornecimento de mudas, armazenamento das mudas, plantio propriamente dito, controle de pragas, controle de formiga, irrigação, quando necessário, replantio e capina. $\mathrm{O}$ fornecimento das mudas é realizado pela Aracruz em todos os modelos de contrato. $\mathrm{O}$ valor das mudas só é cobrado do produtor quando este não acata a cláusula contratual de venda da madeira para a Aracruz; e, 
Estudo ambiental para os programas de fomento...

Quadro 20: Aspectos Ambientais das Propriedades Amostradas

\begin{tabular}{|c|c|c|}
\hline ITEM & NÚMERO DE PRODUTORES & $(\%)$ \\
\hline \multicolumn{3}{|l|}{ Respeitou Cursos de Água } \\
\hline - Sim & 104 & 91,23 \\
\hline - Não & 5 & 4,39 \\
\hline - Não Existe & 5 & 4,39 \\
\hline \multicolumn{3}{|c|}{ Respeitou Declividade Acentuada } \\
\hline - Sim & 95 & 83,33 \\
\hline - Não & 3 & 2,63 \\
\hline - Não Existe & 16 & 14,04 \\
\hline \multicolumn{3}{|l|}{ Respeitou as Nascentes } \\
\hline - Sim & 109 & 95,61 \\
\hline - Não & 3 & 2,63 \\
\hline - Não Existe & 2 & 1,75 \\
\hline \multicolumn{3}{|l|}{ Respeitou os Topos de Morro } \\
\hline - Sim & 94 & 82,46 \\
\hline - Não & 4 & 3,51 \\
\hline - Não Existe & 16 & 14,04 \\
\hline \multicolumn{3}{|c|}{ Quantidade de Água Após Plantio } \\
\hline - Aumentou & 4 & 3,51 \\
\hline - Diminuiu & 16 & 14,04 \\
\hline - Não Mudou & 78 & 79,82 \\
\hline - Não Opinou & 16 & 14,04 \\
\hline \multicolumn{3}{|l|}{ Qualidade do Solo Após Plantio } \\
\hline - Melhorou & 85 & 74,56 \\
\hline - Piorou & 1 & 0,88 \\
\hline - Não Mudou & 12 & 10,53 \\
\hline - Não Opinou & 16 & 14,04 \\
\hline TOTAL & 114 & 100,00 \\
\hline
\end{tabular}

- Condução / Manutenção - É composta pelas atividades de capina, que variam em quantidade e intensidade de acordo com a época e fase de desenvolvimento do projeto necessidade de limpeza dos aceiros e controle à formiga.

\subsection{3 - Colheita da Madeira}

A colheita da madeira compreende a fase da produção florestal, onde são desenvolvidas as atividade de limpeza da floresta, combate à formiga, manutenção/abertura de estradas e aceiros e colheita propriamente dita.

- Limpeza da Floresta - é a retirada do sub-bosque, apenas o necessário, para a derrubada das árvores, procurando atender as práticas de conservação do sub-bosque na área de plantio. Tem como principal função reduzir o risco de acidentes, aumentar a produtividade do operador de motosserra e reduzir o desgaste da corrente de corte; e

- Colheita Florestal - envolve as atividades de combate à formiga, de corte (derrubada, orientação de queda e altura de tocos, desgalhamento, traçamento ou toragem e empilhamento), transporte a curtas distâncias (baldeio ou arraste), quando necessário, empilhamento, manutenção e abertura de estradas. 


\subsection{4 - Transporte da Madeira}

A atividade de transporte é composta pelas operações de carregamento e transporte da madeira, entre as propriedades dos produtores e o depósito da Aracruz.

- Carregamento - pegar a madeira na área de corte, na beira de carreadores ou de estradas e colocá-la nos caminhões para transporte. Pode ser realizada manual ou mecanicamente; e

- Transporte - deslocamento da madeira da área de colheita até o depósito de madeira. Normalmente é realizada por caminhões do tipo toco com capacidade de 18 a 20 estéreos, ou trucados $(6 \times 2)$ com capacidade de 25 a 28 estéreos. No entanto, a preferência deveria ser dada para caminhões trucados do tipo $6 \times 4$ (tração dupla), que permitiriam a redução no custo do transporte.

\subsection{5 - Continuidade do Programa}

A continuidade do programa é definida por duas fases distintas:

- Contratação do $2^{\circ}$ Ciclo de Produção da Floresta - as atividades previstas são a renovação do contrato, a condução da rebrota, manutenção da floresta e a colheita da madeira; e,

- Contrato de Compra e Venda do $1^{\circ}$ Ciclo.

\subsection{6 - Insumos}

Os insumos fornecidos aos produtores fomentados, pela Aracruz, são caracterizados pelas mudas, iscas formicidas, adubos $\mathrm{e}$ assistência técnica. O resumo das quantidades médias fornecidas e preços equivalentes consta no quadro 21. Vale ressaltar que o transporte destes insumos é todo realizado pela Aracruz.

Quadro 21: Quantidades e Custos dos Insumos Fornecidos aos Produtores Participantes do Programa Considerando o Espaçamento Padrão de Plantio de 2,5 $\mathrm{m}$ x 2,5 m

\begin{tabular}{|lc|c|c|}
\hline \hline \multicolumn{1}{|c|}{ ITEM } & & $\begin{array}{c}\text { QUANTIDADE } \\
(\mathbf{n} / \mathbf{h a})\end{array}$ & $\begin{array}{c}\text { VALOR } \\
\text { (R\$/ha) }\end{array}$ \\
\hline \hline Primeiro Ciclo & - & - & $\mathbf{5 7 8 , 8 8}$ \\
\hline - Mudas (Plantio e Replantio) & $(\mathrm{ud})$ & 1.760 & 176,00 \\
\hline - Iscas Formicidas & $(\mathrm{kg})$ & 4,0 & 12,40 \\
\hline - Adubo & & & 64,00 \\
\hline - Plantio (NPK 06-30-06) & $(\mathrm{kg})$ & 160,0 & 51,20 \\
\hline - Cobertura 3 meses (NPK 10-00-20) & $(\mathrm{kg})$ & 160,0 & 51,20 \\
\hline - Cobertura 12 meses (NPK 10-00-20) * & $(\mathrm{kg})$ & 160,0 & 84,00 \\
\hline - Fosfato Natural Reativo & $(\mathrm{kg})$ & 400,0 & 140,08 \\
\hline - Assistência Técnica & $(\mathrm{n})$ & Várias & $\mathbf{3 3 8 , 8 8}$ \\
\hline Segundo Ciclo & - & - & 51,20 \\
\hline - Adubação de Cobertura para Rebrota (NPK 10-00-20) & $(\mathrm{kg})$ & 160,0 & 51,20 \\
\hline - Adubação de cobertura 12 meses (NPK 10-00-20) * & $(\mathrm{kg})$ & 160 & 12,40 \\
\hline - Iscas Formicidas & $(\mathrm{kg})$ & 4,0 & 84,00 \\
\hline - Fosfato Natural Reativo & $(\mathrm{kg})$ & 400,0 & 140,08 \\
\hline - Assistência Técnica & $(\mathrm{n})$ & Várias & $\mathbf{9 1 7 , 7 6}$ \\
\hline \hline
\end{tabular}

*A definição da adubação está sujeita a análise de solo e a critério da ARACRUZ CELULOSE S.A.

Fonte: Aracruz e Banco de Dados da STCP 


\subsection{7 - Práticas Conservacionistas}

Em todas as situações, o corpo técnico da Aracruz tem orientado os produtores a adotar as seguintes medidas de conservação:

- Adotar o sistema de plantio direto, principalmente em terrenos com maior inclinação. Esta medida consiste em fazer somente a cova e limpeza ao redor da mesma. Quando necessária a capina, enleirar os resíduos no sentido perpendicular à declividade (queda) natural do terreno;

- Efetuar o plantio alternado das mudas nas entrelinhas, aumentando a resistência a processos erosivos nos primeiros anos do plantio;

- Realizar a capina somente quando a infestação de ervas seja prejudicial às mudas de Eucalyptus;

- Permitir o desenvolvimento de subbosque quando as plantas de Eucalyptus estiverem estabelecidas (a partir do segundo ano);

- Realizar a aplicação de herbicidas somente quando não houver outra alternativa de combate às ervas daninhas;

- Construir e/ou manter estradas ou carreadores, somente na época de colheita da madeira;

- Projetar os plantios respeitando as áreas de preservação permanente conforme estabelece a legislação vigente;

- Promover o plantio dos 3\% de mudas nativas fornecidas pela Aracruz (48 mudas de nativas para cada 1,0 ha de Eucalyptus plantado), principalmente nas áreas de preservação permanente, visando a melhoria da qualidade da água e manutenção da fauna e flora local;

- Utilizar os 3\% da produção florestal previsto em contrato para o consumo próprio (construções, palanques, etc.), promovendo a redução da pressão sobre áreas com cobertura florestal natural ainda existente no Estado;

- Na roçada antes da colheita, retirar o mínimo necessário de sub-bosque; e,
- Efetuar o plantio do Eucalyptus preferencialmente em áreas degradadas, de baixa produtividade, procurando evitar as áreas ocupadas com outras culturas e nunca em áreas com cobertura florestal natural primária ou secundária.

\section{9 - Síntese dos Custos}

O custo de produção por hectare, somados o primeiro e segundo ciclos dos plantios participantes do Programa de Fomento, corresponde a R $\$ 7.538,40 /$ ha (sete mil, quinhentos e trinta e oito reais e quarenta centavos por hectare), conforme mostra $\mathrm{o}$ quadro 22.

Do custo total, R\$ 937,36/ha (novecentos e trinta e sete reais e trinta e seis centavos por hectare), referentes aos insumos, são de responsabilidade da Aracruz, sem custo adicional para o produto. Se a produção final for vendida para a mesma, o restante é de responsabilidade do produtor. A Aracruz ainda promove adiantamentos financeiros, tanto na implantação como na colheita florestal, que serão cobrados do produtor pela equivalência em madeira, quando a produção for entregue no depósito da empresa.

Caso o produtor decida vender a madeira para terceiros, o custo total de produção representado pelos adiantamentos financeiros, insumos e a assistência técnica, transforma-se em custo real, sem descontos e acrescidos de multa de $10 \%$, incidente sobre a produção estimada do projeto (regra prevista nos contratos do Programa de Fomento).

\subsection{0 - Comparativo entre os Custos e Receitas do Programa de Fomento}

O comparativo entre os custos e receitas (bruta e líquida), relativos aos plantios participantes do Programa de Fomento Florestal da Aracruz foi definido em função do sistema manual, descontados os custos assumidos pela Aracruz, relativos aos insumos fornecidos. O quadro 23 mostra os resultados obtidos para o sistema manual (amplamente adotado pelos produtores fomentados), abordando o primeiro e segundo ciclos de produção.

$\mathrm{Na}$ definição das receitas auferidas, foram consideradas as produtividades médias de $304 \mathrm{st} / \mathrm{ha}$ para o primeiro ciclo e $274 \mathrm{st} / \mathrm{ha}$ 
para o segundo ciclo, baseadas nos levantamentos efetuados pela Aracruz nos plantios fomentados. Para ambos os ciclos, o período de rotação médio adotado foi de 6,5 anos.

Como os preços da madeira praticados pela Aracruz variam em função do depósito de madeira, foi adotado, para efeitos de simulação, o preço médio de $\mathrm{R} \$ 16,37 / \mathrm{st}$ (dezesseis reais e trinta e sete centavos por estéreo), não incluindo os bônus por entrega em dia da madeira e por entrega das toras com comprimentos de $3,0 \mathrm{~m}$ ou $6,0 \mathrm{~m}$.

\section{8 - PLANOS E PROGRAMAS GOVERNAMENTAIS}

O Estado do Espírito Santo mantém vários planos e/ou programas em desenvolvimento relativos ao estudo, conservação e preservação dos meios físicos, biológicos e socioeconômicos. Dessa forma, no presente item, são apresentados os Programas Gerais (relacionados à infraestrutura, incentivos às atividades produtivas, desenvolvimento regional, programas sociais, e os vinculados à produção agropecuária) e o Programa de Extensão Florestal do Governo do Estado.

\section{1 - Gerais}

\subsection{1 - Infra-estrutura}

O Estado do Espírito Santo possui, se comparado às outras unidades da federação, uma posição privilegiada relativa à infraestrutura de transporte e portos marítimos. Esta situação, aliada à localização estratégica e clima favorável à cultura florestal, permitiu nos últimos anos, a instalação de grandes projetos no Estado, proporcionando a criação de divisas e aumentando a participação no cenário produtivo nacional, tanto que os portos Capixabas são responsáveis por $25 \%$ da carga movimentada nos portos brasileiros e pela arrecadação de US\$ 5,2 bilhões das exportações relativas ao escoamento de produtos produzidos no Brasil.

\section{- Transportes:}

- Rodoviário: o principal investimento previsto na área rodoviária (ADERES, 1998) é a duplicação do contorno de Vitória, objetivando a racionalização e o deslocamento do fluxo de transporte de cargas e de veículos na BR-101 norte. Vários investimentos relativos ao recapeamento e asfaltamento e duplicação de rodovias estaduais e municipais são previstos, na ordem de US\$ 98,5 milhões, sendo $25 \%$ deste montante de responsabilidade do Governo Estadual, e os $75 \%$ restantes com recursos do BNDES (Banco Nacional de Desenvolvimento Econômico e Social). Alguns projetos encontram-se em andamento, como é o caso da rodovia entre os Municípios de Santa Tereza e Domingos Martins;

- Ferroviário: O principal investimento articulado neste setor é a construção da Ferrovia Litorânea Norte, prevendo investimentos na ordem de US\$ 296 milhões para a construção de um ramal de $336 \mathrm{~km}$, entre o Porto Barra do Riacho e a Cidade de Taquari, no sul da Bahia, para o escoamento de madeira, celulose, papel, carvão e produtos oriundos da fruticultura;

- Marítimo: o de maior destaque para a área de influência do Programa de Fomento é o Porto de Barra do Riacho (PORTOCEL), onde a previsão de investimentos está entre US\$ 80 e US\$ 120 milhões, necessários para a dragagem do canal de acesso para permitir a atracagem de navios de até 65.000 TDW e calado de 46', com ampliação e aprofundamento da bacia, e a construção de quatro a sete berços; e,

- Aeroviário: destaque para o aeroporto de Linhares que está inserido num projeto de ampliação da infra-estrutura aeroportuária do Estado, onde são previstos investimentos nos próximos anos. 
Quadro 22: Síntese dos Custos do Programa de Fomento Florestal Processo Manual

\begin{tabular}{|c|c|c|}
\hline ATIVIDADE & AÇ̃̃O & CUSTO (R\$/ha) \\
\hline \multicolumn{2}{|c|}{ FASE: IMPLANTAÇÃO DA FLORESTA } & 851,01 \\
\hline \multirow[t]{9}{*}{ PREPARO DO TERRENO } & & 568,32 \\
\hline & Limpeza da área & 130,8 \\
\hline & Combate à formiga & 9,45 \\
\hline & Alinhamento, marcação, abertura de covas e adubação & 235,44 \\
\hline & Plantio & 39,24 \\
\hline & Repasse a Formiga & 9,45 \\
\hline & Irrigação & 21,97 \\
\hline & Replantio & 17,33 \\
\hline & Capina & 104,64 \\
\hline \multirow{3}{*}{ MANUTENÇÃO } & & 282,69 \\
\hline & Manutenção $2^{\underline{0}}$ ano & 87,93 \\
\hline & Manutenção $3^{\circ}$ ao $6^{\circ}$ anos & 194,76 \\
\hline \multicolumn{2}{|l|}{ FASE: COLHEITA DA MADEIRA } & $\mathbf{2 . 7 8 1 , 8 8}$ \\
\hline LIMPEZA DA FLORESTA & & 49,05 \\
\hline COMBATE À FORMIGA & & 9,45 \\
\hline \multirow[t]{4}{*}{ ESTRADAS E ACEIROS } & & 148,5 \\
\hline & Abertura de estradas internas & 98,03 \\
\hline & Manutenção de estradas & 11,23 \\
\hline & Manutenção de aceiros & 39,24 \\
\hline \multirow[t]{4}{*}{ COLHEITA } & & 933,28 \\
\hline & Derrubada, desgalhamento e traçamento & 480,32 \\
\hline & Baldeio/tombamento & 273,6 \\
\hline & Empilhamento & 179,36 \\
\hline \multirow[t]{3}{*}{ TRANSPORTE } & & $1.641,60$ \\
\hline & Carregamento & 273,6 \\
\hline & Transporte propriamente dito & $1.368,00$ \\
\hline \multicolumn{2}{|c|}{ FASE: CONTINUIDADE DO PROGRAMA } & $2.968,15$ \\
\hline \multirow[t]{6}{*}{ CONDUÇÃO DA REBROTA } & & 257,97 \\
\hline & Desbrota & 39,24 \\
\hline & Capina & 39,24 \\
\hline & Manutenção de aceiros & 39,24 \\
\hline & Repasse a formiga & 9,45 \\
\hline & Adubação & 130,8 \\
\hline \multirow[t]{2}{*}{ MANUTENÇÃO } & & 392,4 \\
\hline & Manutenção de $9^{0}$ do $13^{\circ}$ anos & 392,4 \\
\hline \multirow[t]{4}{*}{ COLHEITA } & & 841,18 \\
\hline & Derrubada, desgalhamento e traçamento & 432,92 \\
\hline & Baldeio/tombamento & 246,6 \\
\hline & Empilhamento & 161,66 \\
\hline \multirow[t]{3}{*}{ TRANSPORTE } & & $1.476,60$ \\
\hline & Carregamento & 243,6 \\
\hline & Transporte propriamente dito & $1.233,00$ \\
\hline \multicolumn{2}{|l|}{ INSUMOS FORNECIDOS } & 937,36 \\
\hline \multirow[t]{7}{*}{ PRIMEIRO CICLO } & & 590,64 \\
\hline & Mudas e transporte das mudas & 177,96 \\
\hline & Adubo para plantio e transporte & 65,96 \\
\hline & Fosfato Natural Reativo e Transporte & 85,96 \\
\hline & Adubo de Cobertura e Transporte & 106,32 \\
\hline & Iscas formicidas e transporte & 14,36 \\
\hline & Assistência Técnica & 140,08 \\
\hline \multirow[t]{5}{*}{ SEGUNDO CICLO } & & 346,72 \\
\hline & Adubo de cobertura e transporte & 106,32 \\
\hline & Iscas formicidas e transporte & 85,96 \\
\hline & Fosfato Natural Reativo e Transporte & 14,36 \\
\hline & Assistência Técnica & 140,08 \\
\hline \multicolumn{2}{|c|}{ 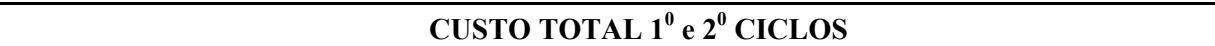 } & $7.538,40$ \\
\hline
\end{tabular}

Fonte: ARACRUZ (1994) e Banco de Dados STCP (2000) 
Quadro 23: Comparativo Entre os Custos e Receitas do Programa de Fomento Florestal da Aracruz

\begin{tabular}{|c|c|c|c|c|c|}
\hline \multirow{2}{*}{\multicolumn{2}{|c|}{ ITEM }} & \multirow{2}{*}{ 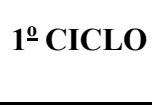 } & \multirow{2}{*}{$2^{\circ}$ CICLO } & \multicolumn{2}{|c|}{ TOTAL } \\
\hline & & & & (R\$/ha) & $(\%)$ \\
\hline \multicolumn{6}{|c|}{ CUSTOS } \\
\hline Produtor & $\mathrm{R} \$ /$ ha.ciclo & $3.632,89$ & $2.968,15$ & $6.601,04$ & 87,6 \\
\hline Aracruz & $\mathrm{R} \$ /$ ha.ciclo & 590,64 & 346,72 & 937,36 & 12,4 \\
\hline Total & R\$/ha.ciclo & $4.223,53$ & $\mathbf{3 . 3 1 4 , 8 7}$ & $7.538,40$ & 100,0 \\
\hline \multicolumn{6}{|c|}{ RECEITAS DO PRODUTOR } \\
\hline Bruta & $\mathrm{R} \$ /$ ha.ciclo & $4.976,48$ & $4.485,38$ & 9461,86 & 100,0 \\
\hline \multirow{4}{*}{ Líquida } & R\$/ha.ciclo & $1.343,59$ & $1.517,23$ & $2.860,82$ & 30,2 \\
\hline & R\$/ha.ano & 206,71 & 233,42 & 440,13 & 4,6 \\
\hline & $\mathbf{R} \$ / \mathbf{s t}$ & 4,42 & 5,54 & 9,96 & $\mathbf{0 , 1 1}$ \\
\hline & $\%$ & 27,00 & 33,83 & 30,24 & - \\
\hline \multicolumn{6}{|c|}{ RECEITAS DO PRODUTOR INCLUINDO O CUSTO ARACRUZ } \\
\hline Bruta & $\mathrm{R} \$ /$ ha.ciclo & $5.567,12$ & $4.832,10$ & $10.399,22$ & 100,0 \\
\hline \multirow{4}{*}{ Líquida } & $\mathbf{R} \$ /$ ha.ciclo & $1.934,23$ & $1.863,95$ & $3.798,18$ & 36,5 \\
\hline & R\$/ha.ano & 297,57 & 286,76 & 584,34 & 5,6 \\
\hline & $\mathbf{R} \$ / \mathbf{s t}$ & 6,36 & 6,80 & 13,17 & $\mathbf{0 , 1 3}$ \\
\hline & $\%$ & 34,74 & 38,57 & 36,52 & - \\
\hline
\end{tabular}

* Receita Líquida $=$ Receita Bruta - Custo do Produtor

Fonte: ARACRUZ (1994) e Banco de Dados STCP (2000)

\section{- Energia:}

Oito das principais usinas do Estado, responsáveis por $99,4 \%$ da capacidade de suprimento de energia, estão localizadas na área de influência do Programa de Fomento. A expectativa de investimentos no setor é da ordem de US\$1,0 bilhão, e os principais projetos na área de influência do programa são (ADERES, 1998):

- Ampliação do gasoduto de São Mateus - Grande Vitória;

- Usina termoelétrica no Norte do Estado: ampliação da produção de gás natural de $700.000 \mathrm{~m}^{3} / \mathrm{dia}$ para $2.000 .000 \mathrm{~m}^{3} / \mathrm{dia}$;

- Projetos da ESCELSA de geração, transmissão, retransmissão e distribuição de energia elétrica;

- Construção de 3 usinas hidrelétricas nos Municípios de Venda Nova do Imigrante e Castelo; e

- Centrais elétricas de pequeno porte em todo o Estado.

\section{- Outros:}

- Saneamento: investimento no PRODESPOL - Projeto de Despoluição dos Ecossistemas Litorâneos do Espírito Santo, concebido e implementado através de uma parceria entre o Governo do Estado e o Banco Mundial, os recursos para esse projeto também serão utilizados na implantação de $1.000 \mathrm{~km}$ de redes de distribuição, ampliando o abastecimento de água em 48 municípios, no aumento das unidades de tratamento de água e reservatórios, na ampliação do número de ligações prediais em mais de 78 mil e, ainda, na modernização da CESAN (Companhia Espírito Santense de Saneamento); e,

- Comunicação: investimentos pelas empresas TELEMAR e TELEFÔNICA em projetos para a ampliação da infraestrutura de telecomunicações do Estado. 


\subsection{2 - Incentivo às Atividades Produtivas}

O Fórum Socioeconômico do Espírito Santo propôs o Plano Estadual de Desenvolvimento Florestal, com investimentos previstos na ordem de US\$ 652 milhões. Os programas e valores a serem investidos em cada um deles são apresentados no quadro 24 .

\subsection{3 - Desenvolvimento Regional}

No apoio ao desenvolvimento regional, três são as instituições estaduais atuantes (ADERES, 1998): ADERES - Agência de
Desenvolvimento em Rede do Espírito Santo (responsável pelo desenvolvimento do Estado); BANDES - Banco de Desenvolvimento do Espírito Santo (responsável pela administração dos incentivos fiscais fornecidos pelo Estado); e, SUPPIN - Superintendência dos Projetos de Polarização Industrial (autarquia responsabilizada pela seleção, implantação e gerenciamento de áreas estratégicas e próprias para a implantação de conglomerados industriais).

Quadro 24: Investimentos Previstos no Plano Estadual de Desenvolvimento Florestal

\begin{tabular}{|c|c|c|c|}
\hline \multirow{2}{*}{ PROGRAMAS } & \multirow{2}{*}{$\begin{array}{c}\text { ÁREA } \\
\text { (ha) }\end{array}$} & \multicolumn{2}{|c|}{ CUSTOS (US\$) } \\
\hline & & POR HECTARE & TOTAL \\
\hline Zoneamento Socioeconômico e Ecológico ${ }^{(1)}$ & Estadual & - & 200.000 \\
\hline Produção, Coleta e Armazenamento de Sementes Florestais & 735.390 & - & 12.846 .450 \\
\hline - Essências Nativas ${ }^{(2)}$ & 553.830 & 15 & 8.307 .450 \\
\hline - Essências Exóticas ${ }^{(3)}$ & 181.560 & 25 & 4.539 .000 \\
\hline Produção e Distribuição de Mudas de Essências Florestais & 735.390 & - & 351.724 .920 \\
\hline - Mudas Nativas ${ }^{(4)}$ & 553.830 & 600 & 332.298 .000 \\
\hline - Mudas Exóticas ${ }^{(3)}$ & 181.560 & 107 & 19.426 .920 \\
\hline Formação de Florestas de Proteção ${ }^{(5)}$ & & 400 & 221.532 .000 \\
\hline Formação de Florestas de Produção ${ }^{(3)}$ & & 360 & 65.361 .600 \\
\hline TOTAL & - & - & 651.664 .970 \\
\hline
\end{tabular}

Envolvendo recursos de instituições públicas (SEAG e SEAMA) e do setor florestal (Aracruz e Florestas Rio Doce)

(2) Envolvendo recursos oriundos do Tesouro Estadual

(3) Envolvendo recursos oriundos da iniciativa privada

(4) Envolvendo recursos de origem múltipla (tesouro estadual, fontes internacionais, prefeituras e iniciativa privada)

(5) Envolvendo recursos oriundos dos produtores rurais beneficiados com os plantios

Fonte: Salvador (1992)

\subsection{4 - Programas na Área Ambiental}

O Estado do Espírito Santo, através do BANDES (Banco de Desenvolvimento do Espírito Santo S.A.) dispõe de linhas de financiamento para apoio ao meio ambiente, tais como: PRONATUREZA - Programa de Apoio à Preservação e Restauração da Natureza; PROAPA - Programa de Apoio à Pequena Produção Agrícola; PROCOP/ES-I Subprograma de Apoio à Pesquisa e ao Aperfeiçoamento Tecnológico; PROCOP/ES-I - Subprograma de Apoio Técnico e Financeiro ao Controle da Poluição Industrial; PROCOP/ES-I - Subprograma de Formação de Recursos Humanos; entre outras.

\section{2 - Programa de Extensão Florestal}

O Programa de Extensão Florestal do Governo do Estado do Espírito Santo foi criado com vistas ao atendimento de uma necessidade antiga do governo em promover a descontinuidade dos plantios homogêneos no Estado, através do envolvimento de grupos comunitários, especificamente os pequenos e médios produtores rurais, com a preocupação de redução dos níveis críticos de oferta de matéria-prima florestal ocorrentes no Estado.

No ano de 1991 a Aracruz Celulose S.A. firmou convênio com a SEAG (Secretaria de Estado da Agricultura), criando o Programa de Extensão Florestal do Governo do Estado do Espírito Santo, através do qual era prevista a doação pela Aracruz de 12 milhões de mudas por ano, número este que atualmente foi 
reduzido para 1 milhão de mudas/ano a serem distribuídas no Estado, além da isca formicida necessária, cabendo à ex-EMATER-ES (atual EMCAPER - Empresa Capixaba de Pesquisa e Extensão Rural) a assistência técnica.

\section{- Objetivos do Programa}

- Aumentar a disponibilidade de madeira para evitar e/ou diminuir as pressões sobre as matas nativas, principalmente em relação ao fornecimento de lenha, através do plantio de essências de rápido crescimento;

- Ocupar as áreas improdutivas das propriedades, com a atenção voltada para o controle à erosão e gerar nova fonte de renda para o produtor, auxiliando sua fixação no campo; e,

- Criar consciência do cultivo florestal, restringindo a velha idéia de extrativismo vegetal.

Estima-se que, com o Programa de Extensão Florestal do convênio SEAG/ EMATER/ITCF e apoio da Aracruz, tenham sido implantados até o ano de 1993, 16.939 ha de florestamentos com Eucalyptus, para um total de 45,2 milhões de mudas distribuídas.

\section{- Situação Atual}

- Programa Extensão com Eucalyptus atualmente a responsabilidade do viveiro centralizador da distribuição de mudas no Estado está a cargo da EMCAPER, mas com a invasão do mesmo pelo Movimento dos Sem Terra, em 1998, e a indefinição do Governo Estadual em relação à política a ser adotada, a distribuição de mudas cessou, apesar da Aracruz ainda manter em sua programação o fornecimento das mudas. Segundo dados disponibilizados pela Aracruz Celulose S.A., o número de mudas distribuídas através da extensão florestal com Eucalyptus é cerca de 49,8 milhões, com um custo aproximado de US\$ 6,1 milhões. Sendo que o número de produtores envolvidos é de aproximadamente 18,5 mil, distribuídos em 71 municípios do Estado do Espírito Santo.

- Programa Extensão com Nativas - até o ano de 1999 haviam sido distribuídas cerca de 2,4 milhões de mudas de essências nativas, envolvendo 140 espécies diferentes. $\mathrm{O}$ número de produtores envolvidos segundo a EMCAPER e o IDAF, é de 307, para um total de 508,5 ha, espalhados em 49 municípios capixabas. Assim, estima-se que o investimento somente na produção de mudas foi de US\$302,5 mil.

\section{9 - ÁREA DE PLANTIO NOS PROGRAMAS EM ANÁLISE}

\section{1 - Área Plantada}

Estima-se que a área plantada com Eucalyptus através dos Programas de Fomento Florestal da Aracruz e Extensão do Estado, seja da ordem de 36 mil ha (Aracruz, 2000), sendo o fomento, o responsável por $48,2 \%$ da área total plantada e a extensão por $51,8 \%$, conforme mostra o quadro 25 .

Quadro 25: Área Plantada dos Programas de Fomento e Extensão Florestal no Estado

\begin{tabular}{|l|c|c|c|c|c|c|}
\hline \hline \multirow{2}{*}{ MESORREGIÃO } & \multicolumn{3}{|c|}{ ÁREA (ha) } & \multicolumn{2}{c|}{ PERCENTUAL DA ÁREA (\%) } \\
\cline { 2 - 7 } & FOMENTO & EXTENSÃO & TOTAL & FOMENTO & EXTENSÃO & TOTAL \\
\hline \hline 1- Noroeste & $4.547,52$ & $5.122,60$ & $9.670,12$ & 13,23 & 14,91 & 28,14 \\
\hline 2- Litoral Norte & $5.619,72$ & $2.326,40$ & $7.941,12$ & 16,34 & 6,77 & 23,11 \\
\hline 3- Central & $5.455,96$ & $6.035,90$ & $11.491,86$ & 15,88 & 17,57 & 33,45 \\
\hline 4- Sul & $1.804,20$ & $3.454,80$ & $5.259,00$ & 5,25 & 10,05 & 15,30 \\
\hline \hline \multicolumn{1}{|c|}{ TOTAL } & $\mathbf{1 7 . 4 2 2 , 4 0}$ & $\mathbf{1 6 . 9 3 9 , 7 0 *}$ & $\mathbf{3 4 . 3 6 2 , 1 0}$ & $\mathbf{5 0 , 7 0}$ & $\mathbf{4 9 , 3 0}$ & $\mathbf{1 0 0 , 0 0}$ \\
\hline \hline Total em Jun/2000 & $\mathbf{1 7 . 4 2 2 , 4 0}$ & $\mathbf{1 8 . 7 5 0 , 0 0 * *}$ & $\mathbf{3 6 . 1 7 2 , 4 0}$ & $\mathbf{4 8 , 1 6}$ & $\mathbf{5 1 , 8 4}$ & $\mathbf{1 0 0 , 0 0}$ \\
\hline \hline
\end{tabular}

* Total plantado até o ano de 1998.

** Estimativa STCP em função do número de mudas fornecidas.

Fonte: ARACRUZ (30/06/2000), IDAF e EMATER 


\section{2 - Área a Ser Plantada}

Com base na área projetada pela Aracruz e liberada pela Licença de Operação da SEAMA (Secretaria de Estado de Assuntos de Meio Ambiente do Espírito Santo), o Programa de Fomento Florestal da Aracruz prevê ainda, a implantação de $10.577,60$ ha de florestamentos de Eucalyptus, sem considerar a área a ser cortada.

Em relação ao Programa de Extensão Florestal do Governo do Estado do Espírito Santo, a expectativa de plantio é de aproximadamente 500 ha anuais.

Os valores referentes às áreas de plantio dos referidos programas, poderão ser alterados em função dos resultados obtidos com o presente estudo, como também da aceitação pelo Ministério Público Federal e das políticas a serem adotadas, tanto pelo Governo do Estado como pela Aracruz Celulose S.A.

\section{0 - IMPACTOS AMBIENTAIS NAS ÁREAS INSERIDAS NO PROGRAMA DE FOMENTO FLORESTAL DA ARACRUZ}

Impacto Ambiental (BOLEA, 1984) é definido como uma alteração favorável ou desfavorável no meio ambiente, ou em alguns de seus componentes, produzido por uma determinada ação ou atividade. No entanto, HOLGATE (1979) define Impacto Ambiental como a alteração das propriedades físicas, químicas e biológicas sobre o meio ambiente, provocadas por qualquer forma de energia ou matéria resultante das ações humanas.

Portanto, a identificação e análise dos impactos ambientais são de fundamental importância na previsão do quadro ambiental a ser gerado na implantação do Programa de Fomento Florestal, pois permitirá a proposição de novas ações para adaptação do projeto às condições ambientais existentes, objetivando tornar o quadro ambiental mais positivo possível.

A avaliação dos impactos foi efetuada através da matriz de impactos, onde se relaciona a qualificação e quantificação dos efeitos de cada uma das atividades propostas no programa, sobre os componentes ambientais.
A metodologia adotada está embasada na proposição de LEOPOLD et al. (1971) onde, nas linhas, são apresentadas as atividades a serem desenvolvidas pelo Programa de Fomento Florestal e, nas colunas, os componentes ambientais. O ponto de encontro de uma atividade do Fomento Florestal com um componente ambiental determina uma célula.

A célula, por sua vez, é a unidade básica da matriz, que será qualificada e posteriormente quantificada, através da adoção de valores que promoverão o dimensionamento do efeito da atividade sobre o componente ambiental.

No presente estudo, foram realizadas algumas modificações à matriz de Leopold op. cit., procurando adaptá-la ao Fomento Florestal, através de alterações nos componentes ambientais. Outra alteração realizada na matriz de Leopold, foi a introdução de mais dois valores na avaliação da relação entre atividade e componente ambiental, abordando o prazo de efeito do impacto e o horizonte de tempo em que esse ocorre.

Nesse método de avaliação são geradas duas matrizes: a primeira trata da relação entre as atividades e os componentes ambientais e a segunda relaciona as medidas e programas aos componentes ambientais.

$\mathrm{Na}$ matriz de impactos ambientais, foi realizada uma avaliação qualitativa de cada uma das inter-relações e, posteriormente, cada um dos atributos das células foi valorado numa escala que vai de 1 a 3 .

\section{- Qualificação dos Impactos}

A qualificação dos impactos ambientais foi realizada considerando que: cada uma das células que corresponde à inter-relação entre uma ação ou atividade do Programa de Fomento Florestal e um componente ambiental (figura 10), propicia uma avaliação, de acordo com cinco atributos, a saber:

- Tipo de impacto;

- Magnitude do impacto;

- Amplitude do impacto;

- Prazo do efeito do impacto;

- Horizonte de tempo do impacto. 


\section{TIPO DE IMPACTO}
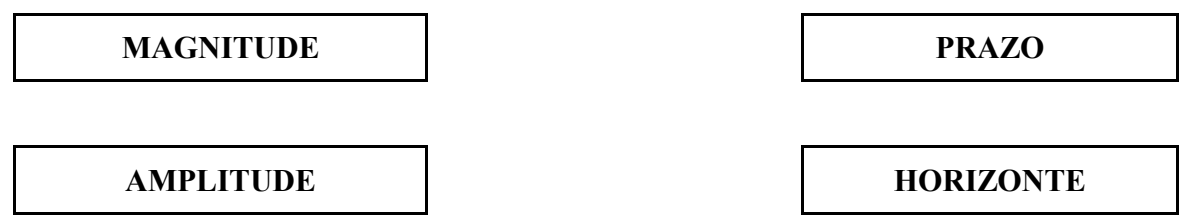

Figura 10: Estrutura de cada Célula da Matriz Ambiental

- Tipo de Impacto: foram classificados em: Positivos (+ ) ou Negativos ( - );

- Magnitude: tem por objetivo indicar a grandeza ou tamanho do impacto, sendo que os mesmos foram classificados em: Pequeno (P); Médio (M); e, Grande (G).

- Amplitude: objetiva avaliar o nível de abrangência do impacto, tendo sido classificados em: Local (L), abrange apenas a área de influência direta do Fomento Florestal; Regional (R), abrange toda a área de influência indireta do Fomento Florestal; e, Estratégico (E), abrange áreas que estão além da área de influência indireta do Fomento Florestal.

- Prazo do Efeito: tem por objetivo avaliar o período de tempo no qual o impacto irá se manifestar, com a seguinte definição: Curto Prazo (CP) com pequena duração (no máximo 2 anos); Médio Prazo (MP) com duração entre 2 e 4 anos; e, Longo Prazo (LP) com duração acima de 4 anos.

- Horizonte de Tempo: tem por objetivo determinar o período de permanência do impacto, sendo mensurado através dos seguintes critérios: Temporário (T) permanecerá parte do tempo (0 a 1 ano) sem repetição; Cíclico (C) permanecerá parte do tempo com repetições periódicas; e, Permanente (P) permanecerá durante todo Fomento Florestal.

Os Impactos Ambientais por monoculturas de Eucalyptus vão desde a retirada da vegetação existente, preparo do solo, plantio, manutenção/condução, adubação, combate à formiga e/ou pragas, movimentação da mão-de-obra, até a movimentação de caminhões, máquinas e equipamentos para derrubada, carregamento e transporte da madeira à unidade de produção.

Dessa forma, na descrição e análise dos impactos ambientais gerados pelo Programa de Fomento Florestal da Aracruz foram consideradas as ações ou atividades a serem desenvolvidas durante o planejamento, implantação, colheita e continuidade do mesmo, sendo os fatores ambientais água, ar, solos, flora, fauna, população, infra-estrutura, patrimônios naturais e economia que deverão sofrer os impactos das atividades previstas no Programa, subdivididos em componentes ambientais.

\section{- Quantificação dos Impactos}

$\mathrm{Na}$ quantificação dos impactos foram valorados cada um dos atributos utilizados na avaliação qualitativa. Estes valores correspondem a uma escala que varia de 1 a 3 , (quadro 26), e a soma destes representam o valor do impacto gerado em cada uma das células. A soma dos valores da célula receberá o sinal correspondente ao tipo de impacto, positivo ou negativo, como exemplificado na figura 11 .

No quadro 27 é apresentado um resumo da quantificação dos impactos decorrentes do Programa de Fomento. Os valores apresentados representam o somatório de todos os impactos definidos para os meios físico, biológico e socioeconômico em cada uma das fases do Programa.

A partir do quadro 27 é possível perceber que apesar dos impactos negativos existentes, o balanço total do Programa é positivo, sendo que os impactos negativos verificados podem ser mitigados/minimizados através das medidas propostas no item 11 . 
Quadro 26: Critérios Para Valoração dos Impactos Ambientais

\begin{tabular}{|l|c|c|}
\hline \multicolumn{1}{|c|}{ ATRIBUTO } & SÍMBOLO & VALOR \\
\hline \hline MAGNITUDE & $\mathrm{P}$ & 1 \\
Pequeno & $\mathrm{M}$ & 2 \\
Médio & $\mathrm{G}$ & 3 \\
Grande & & \\
\hline AMPLITUDE & $\mathrm{L}$ & 1 \\
Local & $\mathrm{R}$ & 2 \\
Regional & $\mathrm{E}$ & 3 \\
Estratégico & $\mathrm{CP}$ & 1 \\
\hline PRAZO DO EFEITO & $\mathrm{MP}$ & 2 \\
Curto Prazo & $\mathrm{LP}$ & 3 \\
Médio Prazo & $\mathrm{T}$ & 1 \\
Longo Prazo & $\mathrm{C}$ & 2 \\
\hline HORIZONTE DE TEMPO & $\mathrm{P}$ & 3 \\
Temporário & \multicolumn{2}{|c|}{} \\
Cíclico & \\
Permanente &
\end{tabular}

Fonte: STCP
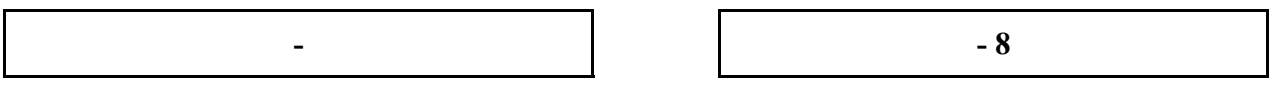

\begin{tabular}{|l|l|}
\hline M & LP \\
\hline
\end{tabular}
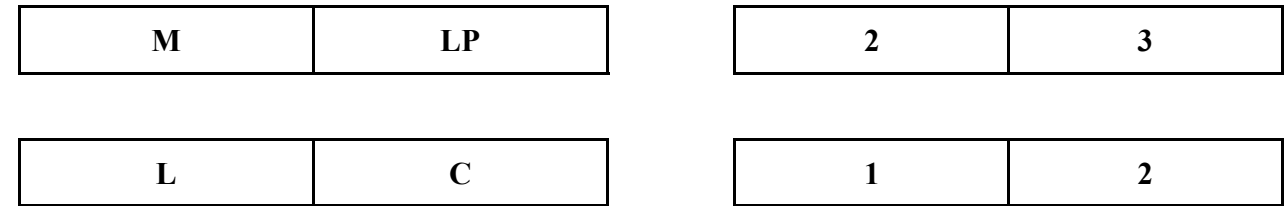

Figura 11: Exemplo de Célula com Qualificação e Quantificação dos Impactos

Quadro 27: Resumo da Quantificação dos Impactos

\begin{tabular}{|c|l|c|}
\hline \multirow{4}{*}{ MEIOS } & \multicolumn{1}{|c|}{ FATORES AMBIENTAIS } & VALORES \\
\hline \hline \multirow{4}{*}{ Físico } & $\mathrm{Ar}$ & -21 \\
\cline { 2 - 3 } & Água & -28 \\
\cline { 2 - 3 } & Solo / Subsolo & -9 \\
\cline { 2 - 3 } & Subtotal & -58 \\
\hline \multirow{4}{*}{ Biológico } & Flora & -3 \\
\cline { 2 - 3 } & Fauna & -28 \\
\cline { 2 - 3 } & Subtotal & -31 \\
\hline \multirow{5}{*}{ Socioeconômico } & População Local & -15 \\
\cline { 2 - 3 } & Patrimônio Natural & +65 \\
\cline { 2 - 3 } & Economia Regional - Diretos & +60 \\
\cline { 2 - 3 } & Economia Regional - Indiretos & +174 \\
\cline { 2 - 3 } & Subtotal & $+\mathbf{8 5}$ \\
\hline \hline
\end{tabular}




\section{1 - Impactos Ambientais do Programa de Fomento Florestal}

A partir do balanço total da matriz ambiental do Programa de Fomento Florestal, são apresentadas as seguintes considerações:

\section{- Meio Físico}

- Ar: os principais impactos que contribuíram para o balanço negativo (-21) dizem respeito à emissão de gases (principalmente $\mathrm{CO}_{2}$ e poeira) e o aumento da temperatura que irão ocorre durante as fases de implantação (preparo do solo), colheita (abertura de estradas, operações de colheita e transporte da madeira) e continuidade (transporte da madeira). Vale ressaltar que a adoção de medidas mitigadoras pode facilmente reverter esse processo. Outra consideração importante é a verificação da ocorrência de impactos positivos de captura de $\mathrm{CO}_{2}$ e redução da temperatura do ar, com aumento da umidade relativa, que irão ocorrer nas fases de implantação e continuidade devido ao crescimento da floresta.

- Água: os impactos negativos sobre as águas referem-se à alteração na sua qualidade, ocasionada por processos erosivos, lixiviação de componentes químicos das iscas formicidas e dos adubos. A adoção de medidas de controle para redução e utilização racional (de acordo com normas técnicas pré-estabelecidas) destes produtos, em especial o adubo, permitirá a redução dos impactos. Também foram verificados impactos positivos da implantação do Programa de Fomento para o fator água, são eles: o melhor aproveitamento da água disponível e a redução da carga de sedimentos na água, devido ao processo de contenção da erosão que ocorrerá quando a floresta estiver em processo de crescimento.

- Solo e Subsolo: os principais impactos que contribuíram para o balanço negativo (-9) da análise deste fator dizem respeito à presença do formicida e aos processos erosivos e compactação do solo. Por outro lado, os impactos positivos, causados pelo aumento das taxas de nutrientes, a melhora do $\mathrm{pH}$ do solo e o melhor aproveitamento dos nutrientes, provocado pelo aumento da cobertura vegetal, são muito mais significativos. Medidas de controle e adoção de técnicas apropriadas ao plantio de florestas, como a técnica do cultivo mínimo, deverão ser adotadas e poderão facilmente mitigar e/ou reverter os processos impactantes comentados anteriormente.

\section{- Meio Biológico}

- A abordagem dos impactos sobre a fauna e a flora é realizada, considerando suas interações na área de influência direta e o desequilíbrio que poderá ocorrer com a retirada da vegetação. Os impactos mais preocupantes sobre a flora e a fauna são relativos à redução da biodiversidade, principalmente na fase de implantação do projeto de reflorestamento, quando ocorrer a retirada da vegetação original. Porém, são impactos temporários e que poderão ser superados com 0 crescimento da floresta e do sub-bosque após o plantio.

- Outro fator a considerar é que a grande maioria dos plantios fomentados pela Aracruz foram implantados em áreas degradadas ou ocupadas por outras culturas, como o café e a pastagem, portanto, já com a diversidade de espécies bastante comprometida. Essa situação poderá ser melhorada com a implantação do Programa de Fomento.

- Como os plantios de Eucalyptus são culturas de ciclo longo e que sofrem poucas interferências culturais, os mesmos poderão promover a recuperação da biodiversidade com a possibilidade de crescimento do subbosque e, ao mesmo tempo, criar condições de abrigo e alimentação para a fauna local.

- Vale ressaltar que os resultados obtidos no monitoramento de microbacias da Aracruz, demonstraram que o número de representantes da fauna em florestas 
de Eucalyptus é maior do que em áreas de pastagem e até mesmo de formações nativas.

- Portanto, a recuperação do equilíbrio da fauna e flora poderá ocorrer com o crescimento das florestas de Eucalyptus, readaptando as espécies da flora e da fauna à nova cobertura vegetal. Porém, esse equilíbrio sempre será quebrado a cada operação de colheita, quando novamente ocorre o efeito negativo da retirada da vegetação.

\section{- Meio Socioeconômico}

- População Local: o balanço ambiental do Programa de Fomento sobre a população local (produtor) é bastante positivo $(+64)$, no momento em que: permite um rendimento adicional ao produtor rural fomentado sem que este tenha que se desfazer de seu imóvel; valoriza a propriedade, uma vez que a maioria dos plantios são realizados em áreas degradadas e improdutivas; cria frentes de trabalho, permitindo a ocupação da mão-de-obra local ociosa; fixa o homem no campo com a nova perspectiva de trabalho.

O único impacto de efeito negativo é a redução de áreas a serem ocupadas por outras culturas temporárias ou de ciclo curto. Porém, se considerarmos a baixa produtividade de outras culturas, observadas nas regiões onde foram implantados os plantios de Eucalyptus, os custos dessas culturas são muito mais altos, o que inviabiliza o investimento para o produtor, que acaba por abandonar a área, a qual irá, certamente, sofrer processos erosivos muitas vezes irreversíveis. Portanto, a cultura de Eucalyptus, apesar do ciclo longo, apresenta-se como uma possibilidade mais rentável e que, ao mesmo tempo, pode promover a conservação dos solos.

- Patrimônios Naturais: os impactos causados sobre os patrimônios naturais, são em sua maioria negativos, mas com valores bastante reduzidos e insignificantes do ponto de vista da quantificação. Medidas mitigadoras simples poderão permitir a sua correção.

- Economia Regional: os impactos sobre a economia regional, quer sejam diretos ou indiretos, apresentam as mesmas características observadas para a população local, principalmente no que se refere à expectativa na geração de renda, impostos e ocupação da mãode-obra, permitindo indiretamente criar novas vagas em setores como o de serviços, e até mesmo na Agricultura, com o aumento no consumo de produtos deste setor. Os impactos negativos mais significativos seriam sobre a infra-estrutura, porém de fácil superação pelos órgãos públicos regionais, através da construção e/ou recuperação das estradas municipais e estaduais, aumento da infra-estrutura de escolas, saneamento básico e saúde.

\section{1 - MEDIDAS A SEREM ADOTADAS}

A definição das medidas a serem adotadas teve como base os impactos, tanto negativos como positivos, identificados como inerentes ao Programa de Fomento Florestal. Dessa forma foram definidas medidas minimizadoras ou mitigadoras dos impactos negativos e medidas potencializadoras dos impactos positivos.

\section{1 - Medidas Mitigadoras}

As medidas propostas visam mitigar os impactos ambientais negativos identificados sobre a área de influência do Programa de Fomento Florestal da Aracruz. As medidas e/ou ações propostas foram classificadas de acordo com as seguintes características:

- Natureza: preventiva ou corretiva, inclusive os meios de controle de poluição, avaliando sua eficiência em relação aos critérios de qualidade ambiental;

- Fase do empreendimento em que deverão ser adotadas: planejamento, implantação, continuidade, desativação e em casos de acidentes;

- Fator ambiental a que se destina; 
- Prazo de permanência de sua aplicação - curto prazo, médio prazo ou longo prazo; e,

- Responsabilidade por sua implementação, podendo ser da Aracruz, do produtor ou do poder público.

Para mitigar os impactos gerados pelas ações desenvolvidas durante as fases de implantação do Programa de Fomento, serão executados os seguintes grupos de medidas apresentadas a seguir.

\subsection{1 - Gerais}

- Enquadramento do Programa de Fomento ao SLAP (Sistema de Licenciamento das Atividades Poluidoras), regulamentado pelo Decreto no 4.344-N, de 07 de outubro de 1998 no atendimento aos instrumentos de controle definidos pelo mesmo como: Licença Prévia (LP); Licença de Instalação (LI); Licença de Operação (LO); Estudos Ambientais, quando necessários; EIA/RIMA, quando necessários para o atendimento à legislação vigente; entre outros.

Essa medida é de natureza preventiva e corretiva, devendo atuar em todas as fases do Programa, tendo influência direta ou indireta em todos os fatores ambientais considerados. Cabe a Aracruz a implementação desta medida e ao IDAF a aprovação do projeto e a sua fiscalização.

\subsection{2 - Meio Físico}

- Análise Periódica das Condições Atmosféricas - medida de caráter preventivo e que deverá ocorrer na área de influência do Programa enquanto este estiver ativo. A análise será realizada nos dados obtidos através do Programa de Monitoramento das Condições Atmosféricas a ser desenvolvido pelo órgão público competente e que detém o controle das estações meteorológicas existentes no Estado. À Aracruz caberá o fornecimento de relatório mensal relativo às informações climatológicas (precipitação, déficit/excedente hídrico e variação de temperatura) colhidas nas
12 estações meteorológicas próprias, situadas no Estado;

- Controle da Poluição Atmosférica (emissão de gases e poeira) - medida preventiva e de longo prazo, devendo atuar principalmente nas fases de implantação e colheita e estar embasada na legislação vigente (Portarias do CONAMA e MINTER). Essa medida vincula-se ao processo de manutenção de máquinas e equipamentos que funcionam à combustão, dando atenção especial ao sistema de descarga dos mesmos, através da adoção de métodos de diminuição da produção de monóxido de carbono, de acordo com os níveis de emissão estabelecidos pela legislação vigente. Caberá à Aracruz, estabelecer normas e procedimentos para os veículos contratados pela mesma no transporte de madeira, de acordo com a legislação vigente e realizar auditorias periódicas de avaliação. Porém, a fiscalização caberá aos órgãos competentes, conforme estabelecido em lei;

No relativo aos veículos contratados pelos produtores para o transporte de madeira, a Aracruz deverá distribuir cartilhas informativas aos mesmos onde constem normas e procedimentos, no que se refere à segurança de transporte, velocidade de tráfego, cuidados no carregamento, amarração correta da carga, transporte de passageiros, conservação de veículos, emissão de gases, etc. Como no parágrafo anterior a fiscalização destes veículos caberá aos órgãos públicos competentes;

- Controle das Emissões Sonoras - para evitar os danos causados pelo aumento do nível de ruídos acima do permitido em legislação, deverão ser utilizados EPI's (Equipamentos de Proteção Individual) por todas as pessoas sujeitas a este efeito adverso, bem como deverá ser observado o atendimento aos limites máximos permitidos pela legislação. Essa medida tem caráter preventivo e deverá atuar, principalmente, nas fases de implantação e colheita da madeira, caracterizando-se como uma medida de 
longo prazo. A orientação no uso de EPI's será realizada pela Aracruz através da disponibilização aos produtores fomentados, de cartilhas orientativas. Porém, caberá ao produtor a obrigação na implementação da utilização dos mesmos;

- Avaliação da Qualidade das Águas tem como objetivo avaliar a evolução da qualidade ambiental, através do monitoramento da qualidade da água, dentro dos padrões estabelecidos pela legislação vigente (Resolução CONAMA 020/86, entre outras) e, se necessário, tomar medidas que evitem a degradação da qualidade da mesma. A natureza desta medida é corretiva e/ou preventiva, e deve atuar principalmente nas fases de implantação e colheita da madeira. Sua implementação cabe à Aracruz, a qual deverá utilizar como referencial os resultados obtidos no Programa de Monitoramento de Microbacias realizado pela mesma desde 1994, criando normas e procedimentos que serão repassadas aos produtores através de manuais, cabendo a fiscalização ao órgão público competente;

- Adequação das Atividades de Plantio a implantação dos projetos fomentados deverá ser executada de forma a respeitar as microbacias existentes nas propriedades, permitindo a redução de forma significativa dos custos de construção e manutenção de estradas, quando necessárias, e conseqüente redução dos processos erosivos (perdas de solo). A natureza desta medida é preventiva e deverá atuar, principalmente, nas fases de implantação e continuidade do Programa. Caberá à Aracruz a orientação técnica e ao produtor fomentado a implementação das mesmas;

- Revegetalização de Áreas de Preservação Permanente - tem como objetivo incentivar o produtor a recompor as áreas de preservação permanente na propriedade, utilizando as mudas de espécies nativas disponibilizadas pela Aracruz. Esta medida é de natureza corretiva e/ou preventiva, devendo atuar na fase de implantação do Programa de Fomento, tendo influência sobre os meios físico e biológico, e em menor intensidade sobre o meio socioeconômico. Cabe a Aracruz somente a orientação técnica e a fiscalização, conforme a legislação vigente, caberá ao órgão competente (IDAF);

- Medidas de Proteção Complementares referem-se à efetiva fiscalização do IDAF para o cumprimento da legislação vigente, procurando evitar processos erosivos, degradação do solo e degradação da qualidade ambiental. Entre as atividades de fiscalização destacam-se: uso de margens de rios, córregos, lagos, nascentes e sopé de montanhas ou morros (evitar danos quanto à qualidade das águas, alterações no comportamento da água subterrânea, alterações no ciclo hidrológico local). Esta medida é de natureza preventiva e/ou corretiva e deverá atuar em todas as fases do Programa de Fomento, tendo maior influência nos meios físico e biológico. Cabe ao IDAF sua implementação e fiscalização.

\subsection{3 - Meio Biológico}

- Manutenção de Áreas de Preservação Permanente - a Aracruz deverá incentivar a preservação ou recuperação de áreas com vegetação natural nas propriedades fomentadas, para atender a dois princípios legais: o da preservação permanente de áreas especiais e a manutenção de reserva legal (conforme estabelecido na Lei 4.771/65). Cabe à Aracruz a orientação técnica, ao produtor a implementação e ao IDAF a fiscalização da medida;

- Levantamento da Fauna - tem por objetivo gerar informações que permitam aprofundar os conhecimentos sobre a fauna do Estado, monitorando a fauna e contribuindo para o seu manejo adequado, de modo a minimizar os 
impactos a serem gerados pelos plantios fomentados. Esta medida apresenta caráter preventivo e corretivo e deverá ocorrer em todas as fases do empreendimento, cabendo à Aracruz a implementação da mesma, utilizando-se da estrutura existente no Programa de Monitoramento de Microbacias da mesma; e,

- Monitoramento de Pragas e Doenças nas Áreas Florestais - tem por objetivo estudar a evolução das doenças típicas nos plantios florestais, viveiro de produção de mudas por sementes e estacas de Eucalyptus spp. e espécies nativas. Este tipo de monitoramento é desenvolvido pela Aracruz, em seus plantios, através do Programa de Monitoramento de Microbacias. Tais resultados servirão como balizamento na adoção de medidas, quando necessárias, relacionadas aos plantios fomentados. Esta medida tem caráter preventivo e/ou corretivo e com atuação em todas as fases do Programa de Fomento, cabendo ao produtor alertar a Aracruz, a ocorrência de situação excepcional (anormalidade); e,

- Pesquisa em Produção Florestal - visa promover o estudo e melhoramento de espécies que permitam agregar valor aos produtos florestais obtidos (utilização diversificada como serraria, extração de essências, etc.), como também um melhor aproveitamento dos nutrientes do solo, reduzindo os níveis de acidez e aumentando a taxa de nutrientes disponíveis. Esta medida será desenvolvida pela Aracruz com atuação principal na fase de implantação, cabendo ao Estado, com o apoio técnico da Aracruz, a implementação desta medida.

\subsection{4 - Meio Socioeconômico}

- Educação Ambiental - os programas de Educação Ambiental devem atuar como catalisadores e difusores do saber popular e científico, buscando a formação de recursos humanos para enfrentar desafios, refletir sobre questões ambientais e, sobretudo, discutir soluções para a atuação do homem sobre o patrimônio natural. Esta medida tem natureza preventiva e compensatória. É uma medida de longo prazo, cabendo a sua implementação ao Governo do Estado, com o apoio de órgãos competentes em nível federal, prefeituras municipais, entidades privadas, ONGs e órgãos internacionais.

\section{2 - Medidas Potencializadoras}

As medidas potencializadoras têm como intenção maximizar os impactos positivos que o Programa de Fomento produz sobre as regiões sob sua influência. As medidas mais indicadas para este fim são:

\subsection{1 - Meio Biológico}

- Manutenção de Sub-Bosque - promover junto aos produtores fomentados, técnicas de manejo (tais como plantio mínimo e plantio direto) que permitam um bom desenvolvimento dos plantios de Eucalyptus e, ao mesmo tempo, mantendo e promovendo o crescimento do sub-bosque. Esta medida é de natureza corretiva e/ou preventiva, com atuação principal nas fases de implantação e continuidade do Programa de Fomento. Portanto é uma medida de longo prazo, cabendo à Aracruz a orientação técnica e ao produtor a sua implementação.

\subsection{2 - Meio Socioeconômico}

- Enquadramento do Programa de Fomento na Convenção do Clima (Protocolo de Kyoto) - tem como objetivo promover créditos ou transações internacionais a fundo perdido, relativas principalmente, à redução de emissões de $\mathrm{CO}_{2}$, entre outros compostos, implementados através do mecanismo de desenvolvimento limpo. Com a possibilidade destes investimentos, pretende-se promover medidas que potencializem a implantação de plantios florestais em novas áreas, quer seja para produção ou para proteção, visando à potencialização na redução da temperatura do ar, aumento da 
umidade relativa do ar, captura de $\mathrm{CO}_{2}$, etc. Caberá ao Governo do Estado, através de uma ação coordenada com a Aracruz, promover estudos que permitam classificar os plantios florestais fomentados como geradores de CERs (Certificados de Redução de Emissão), propiciando a negociação destes certificados com países industrializados; e,

- Integração com as Comunidades Locais - tem como principal objetivo tornar disponíveis as informações positivas de outras atividades produtivas, em caráter piloto, que possam contribuir com a população local envolvida diretamente no Programa de Fomento, bem como procurar incentivar os produtores a integrar-se à nova realidade social e econômica do país (propriedades com uso múltiplo), tais como os Sistemas Agroflorestais. Esta medida tem natureza potencializadora, com atuação principalmente na fase de implantação do Programa de Fomento, e devendo ser de longo prazo. Caberá à EMCAPER promover a divulgação de novas técnicas de produção, consorciadas ou não a plantios florestais e à Aracruz orientar os fomentados na adoção de novas tecnologias disponíveis de cultivo do eucalipto.

\section{2 - PROGRAMAS DE MONITORAMENTO AMBIENTAL}

Os programas de monitoramento ambiental foram definidos em função das medidas mitigadoras ou potencializadoras dos impactos ambientais causados pelo Programa de Fomento e são descritos a seguir segundo o meio em que atuam.

\section{1 - Meio Físico}

\section{- Monitoramento das Condições Atmosféricas}

As justificativas para a implementação desse programa são:

- Criar banco de dados que permita avaliar a evolução das condições atmosféricas na região de influência do
Programa de Fomento, o que permitirá inferir sobre a real influência dos maciços florestais;

- Orientar as empresas/terceiros que prestam serviços na colheita e transporte de madeira, quanto à necessidade de manutenção das máquinas, equipamentos e caminhões, mantendo os níveis de poluição atmosférica de acordo com o estabelecido com a legislação vigente; e,

- Orientar os trabalhadores quanto à necessidade do uso de EPI's, em situações que ocorram a poluição sonora ou riscos de acidentes.

As atividades propostas para esse programa referem-se ao levantamento e avaliação das informações de estações climatológicas localizadas nas regiões participantes do Programa de Fomento, relacionadas à temperatura do ar e do solo, pluviosidade, umidade relativa do ar e umidade do solo, direção e velocidade dos ventos, radiação solar e duração do dia claro, tomando-se registros que permitam a geração de série histórica (mensal, semestral e anual). Esses dados serão tratados estatisticamente e analisados por órgão público competente. Para enriquecimento das informações, a Aracruz deverá disponibilizar mensalmente as informações coletadas nas estações climatológicas próprias, situadas nos municípios de Aracruz e São Mateus.

No que diz respeito à emissão de gases, a Aracruz deverá realizar auditorias nas empresas contratadas para o transporte de madeira do depósito até a fábrica, para avaliar se o plano de manutenção e ajuste de caminhões está sendo realizado periodicamente, na intenção de determinar se os níveis de emissão apresentam-se abaixo do especificado pela legislação vigente. Caso contrário, prever sanções contratuais, até que a regulagem de motores ou a instalação de filtros que atendam às normas pré-estabelecidas pela legislação, seja realizada.

Em relação aos caminhões/máquinas contratados pelos produtores fomentados, caberá ao produtor cobrar dos contratados a realização de tais atividades para enquadramento dos equipamentos à legislação. À Aracruz caberá a inclusão na cartilha de 
exploração da orientação necessária aos produtores em relação a esta prática.

A responsabilidade desse programa é atribuída da seguinte forma:

- Caberá ao Estado a instalação, quando necessária, de estações climatológicas e análise dos dados obtidos, e à Aracruz o fornecimento mensal dos dados obtidos nas estações climatológicas próprias;

- Será de responsabilidade da Aracruz a realização de auditorias nas empresas de transporte contratadas pela mesma, para avaliar se estão sendo realizadas as regulagens necessárias em equipamentos no relativo à emissão de gases e ruídos; e,

- A fiscalização e punição, quando extrapolados os níveis de emissão permitidos, caberá ao órgão público competente.

\section{- Monitoramento da Qualidade da Água e} do Nível do Lençol Freático

Este programa se justifica no momento em que, em praticamente todas as fases de desenvolvimento do Programa de Fomento, podem ser geradas situações que venham a interferir direta ou indiretamente na qualidade e quantidade das águas superficiais e subterrâneas das áreas do Programa. Dessa maneira, o acompanhamento ao longo do tempo das possíveis variações do desempenho ambiental, no tocante ao fator águas, reveste-se de grande importância para o gerenciamento das possíveis interferências positivas ou negativas.

Os trabalhos relacionados a este programa deverão desenvolver atividades de escritório, campo e laboratório. A primeira vinculada ao planejamento de execução de todos os trabalhos, bem como das conclusões e de tabulação e análise (análise da qualidade da água e análise do nível do lençol freático) dos resultados laboratoriais. A etapa de campo consistirá na coleta de amostras, de acordo com o estabelecido e acordado entre a Aracruz e o órgão público competente (SEAMA). Estas amostras serão as coletadas atualmente pela Aracruz no projeto de monitoramento de microbacias.

Caso sejam obtidos resultados de comprovação que as práticas adotadas na implantação de florestas de Eucalyptus sejam poluidoras, caberá à Aracruz divulgar tais resultados aos produtores e estabelecer normas e procedimentos que possibilitem mitigar tais efeitos (impactos) sobre a qualidade das águas e lençol freático.

Dessa forma, a responsabilidade pela execução desse programa é atribuída à Aracruz, a qual deverá indicar as medidas corretivas, quando comprovado impacto negativo ou aplicação de produtos acima dos níveis pré-estabelecidos pela legislação e do produtor, implementar as medidas, principalmente, quando comprovado que o mesmo não seguiu as orientações técnicas fornecidas.

\section{2 - Meio Biológico}

\section{- Monitoramento de Áreas de Preservação Permanente}

Esse programa tem como objetivo acompanhar o efetivo cumprimento da legislação em cada propriedade envolvida no Programa de Fomento Florestal da Aracruz. Para isto, enumeram-se as atividades básicas a serem realizadas:

- Croqui completo (perímetro, vegetação, hidrografia, infra-estrutura, sítios de importância, etc.) de cada propriedade, realizado pelo IDAF na fiscalização da propriedade quando da aprovação para instalação do plantio fomentado;

- Atendimento pela Aracruz ao determinado na Licença de Operação do Programa de Fomento, em relação à distância mínima dos leitos d'água, ocupadas com áreas de preservação permanente; e,

- Fiscalização e auxílio técnico do IDAF na recuperação das áreas de preservação permanente que se encontrem alteradas, bem como demais áreas degradadas;

Ressalta-se que boa parte das áreas de preservação permanente encontram-se alteradas, ou desprovidas de cobertura vegetal arbórea. Independentemente disso, a faixa de preservação deverá ser estabelecida e, se for necessário, promover a recomposição de acordo com dados oriundos de outros programas. 
A recuperação das referidas áreas será de responsabilidade dos produtores envolvidos com o Programa de Fomento e caberá à Aracruz disponibilizar as mudas nativas (equivalente a 3\% do fornecido de Eucalyptus) e aos órgãos competentes, fiscalizar (IDAF) a execução de tal programa.

\section{- Revegetalização de Áreas de Preservação Permanente}

A implantação do presente programa está embasada no Plano de Desenvolvimento Florestal do Estado do Espírito Santo, proposto no Fórum Socioeconômico do Espírito Santo e realizado pelo Grupo de Trabalho da Indústria Florestal (ESPÍRITO SANTO, 1992), e ocorrerá em três fases:

- Fase 1 - Identificação das Áreas a serem Recuperadas;

- Fase 2 - Definição de Espécies: a definição de espécies requer ainda, que seja observada a melhor época para plantio ou semeadura; e,

- Fase 3 - Plantio: após o planejamento da atividade, citado nas duas fases anteriores, será executado o plantio propriamente dito, conforme metodologia de plantio adotada pela Aracruz.

Os recursos necessários para $\mathrm{o}$ desenvolvimento do presente programa irão envolver instituições públicas (SEAMA, SEAG, Tesouro Estadual), a iniciativa privada, fontes internacionais e os produtores beneficiados.

\section{- Programa de Pesquisa em Avifauna}

O programa de pesquisa em fauna é composto pelos seguintes sub-programas: levantamento da fauna e monitoramento da fauna. Os levantamentos previstos neste programa já são desenvolvidos pela Aracruz no Projeto de Monitoramento de Microbacias. Portanto, os resultados existentes serão a base para a avaliação da real influência de plantios com Eucalyptus, relacionados ao Programa de Fomento, permitindo a definição das medidas a serem tomadas para mitigar ou potencializar os impactos causados.

Para este programa são sugeridas as seguintes atividades:
- Listar as espécies de aves presentes na região de estudo, subdivididas pelos ambientes, sejam naturais ou plantados;

- Verificar qualquer variação na presença destas espécies ao longo do tempo, buscando encontrar correlações com as práticas culturais comumente usadas nestes plantios e/ou com o processo de regeneração das áreas naturais próximas;

- Estimar índices populacionais das espécies existentes nas áreas naturais sob regeneração ou no plantio durante diferentes estágios de crescimento, tornando-os comparáveis entre si;

- Levantar informações sobre a biologia básica das aves, especialmente no tocante o período reprodutivo, mudas, migrações e vida média, permitindo uma inferência sobre os fluxos de recursos da área e eventuais alterações introduzidas pelas modificações de estrutura do ambiente; e,

- Sugerir e, possivelmente, testar formas de manejo da floresta plantada economicamente viáveis e capazes de reduzir ou evitar quaisquer danos à avifauna e sua composição atual, bem como propiciar o seu enriquecimento com aves originais das formações vegetais e localmente ausentes.

A justificativa para adoção somente do levantamento de Avifauna está baseada, entre outros quesitos, na seguinte questão: a riqueza das espécies de aves presentes num dado ecossistema, reflete, em última análise, a disponibilidade de recursos e as interações dos diversos componentes das cadeias alimentares, inclusive aqueles não diretamente estudados. As inter-relações fauna/fauna e fauna/flora expressam-se na riqueza encontrada de espécies dos diversos grupamentos tróficos em que se dividem as comunidades. Assim, desses estudos, é possível detectar alterações ambientais ao longo do tempo, sejam elas sutis ou drásticas.

As responsabilidades desse programa são atribuídas da seguinte forma:

- Caberá à Aracruz os trabalhos de monitoramento e divulgação dos resultados obtidos, orientação dos 
produtores fomentados em relação à forma mais correta de implantação/ exploração dos plantios florestais no sentido de manutenção e perpetuação da fauna local;

- Aos produtores, caberá, evidentemente, com o auxílio das entidades governamentais competentes, informar/ auxiliar nos procedimentos de manejo da fauna, quando necessário na sua evolução/sobrevivência; e,

- Como medida corretiva e/ou preventiva da manutenção da fauna local poderá ser adotado nos plantios florestais a técnica de consórcio de eucalipto com espécies frutíferas afins à fauna. A adoção desta técnica será de responsabilidade dos produtores, com a orientação técnica da Aracruz, ou de entidades governamentais de pesquisa como a EMCAPER.

\section{- Monitoramento de Doenças e/ou pragas}

A atividade principal a ser executada resume-se nas operações a serem realizadas nos viveiros, onde serão efetuadas observações mensais da produção de mudas por estacas e sementes.

Nos plantios florestais, o monitoramento de doenças será realizado pelo próprio produtor, o qual deverá comunicar à Aracruz, quando constatar a ocorrência de qualquer anormalidade, para que a mesma possa orientar quais os procedimentos e recomendações mais adequados no combate, ou controle fitossanitário das doenças e/ou pragas, principalmente fungos.

\section{- Programa de Manutenção de Sub-bosque}

Esse programa tem como função promover a formação/manutenção de subbosque nos plantios de Eucalyptus, permitindo o aumento da biodiversidade, tanto da flora como da fauna local.

Sua implantação se dará através da adoção de técnicas de manejo que permitam a menor interferência no desenvolvimento de sub-bosque dos plantios florestais fomentados, a exemplo da técnica de cultivo mínimo e a de plantio direto, procurando retirar somente a vegetação que possa prejudicar os plantios de Eucalyptus.
A responsabilidade de execução do presente programa ficará a cargo dos produtores, sendo que caberá à Aracruz a orientação técnica e os procedimentos de implementação.

\section{3 - ESTRATÉGIAS DE CONSOLIDAÇÃO DOS PROGRAMAS DE FOMENTO E EXTENSÃO FLORESTAL}

Como forma de possibilitar a consolidação e a viabilização do Programa de Fomento Florestal da Aracruz e Extensão Florestal do Governo do Estado do Espírito Santo foram propostas duas estratégias: Programas que serão implementados na área de influência do Programa de Fomento e recomendações de uso sustentável das regiões bioclimáticas (aptidão, potencialidades e restrições).

\section{1 - Programas}

\subsection{1 - Programa de Educação Ambiental e Comunicação \\ O Programa de Educação Ambiental e} Comunicação Social ora proposto está embasado no previsto pelo Programa de Desenvolvimento Florestal do Estado do Espírito Santo (ESPÍRITO SANTO, 1992), com a participação de entidades públicas (SEAG, SEAMA, Prefeituras, etc.), privadas (empresas florestais e de outros setores, ONGs, etc.) e internacionais, através do qual deverá ser desenvolvida, junto às comunidades envolvidas no Programa de Fomento, a preservação da diversidade dos diferentes ecossistemas, a identidade e patrimônio cultural, genético, ambiental e antropológico, visando à valorização do equilíbrio entre culturas locais e as tecnologias avançadas.

As formas de atuação do Programa compreendem a Educação Ambiental Formal ou Escolar, a Educação Ambiental não Formal e a Educação Ambiental Informal:

- A primeira forma caracteriza-se por desenvolver-se no ambiente escolar, sendo um processo integrado à educação geral onde as escolas atuam com a função fundamental de educar para a formação e o desenvolvimento de indivíduos conscientes, e com conhecimentos sobre as questões relacionadas ao ambiente onde vivem; 
- A segunda forma compreende os processos pedagógicos destinados à formação ambiental dos indivíduos e grupos sociais fora do sistema de ensino. Dessa forma, devem ocorrer ações para alcançar a conscientização ambiental, a adoção de valores, atitudes, habilidades e comportamentos ambientalmente adequados ao desenvolvimento sustentável e à conservação do meio ambiente. Destina-se a todos os segmentos da sociedade; e,

- A terceira forma constitui os processos destinados a ampliar a conscientização pública sobre as questões ambientais através dos meios de comunicação de massa, como jornais, revistas, rádio e televisão, etc. Inclui-se nesse processo educativo, peças gráficas utilizadas com finalidade didática ou informativa como cartilhas, cartazes, folders, boletins e informativos destinados à informação e sensibilização da sociedade sobre as questões ambientais.

Para a organização, implementação e funcionamento do Programa de Educação Ambiental e Comunicação Social, deverá ser promovida a criação de Centros de Educação Ambiental. Para tal, as responsabilidades deverão ser distribuídas entre o Governo do Estado, Prefeituras Municipais e Entidades Privadas, através da atuação de uma equipe de conhecimento multidisciplinar e global da questão ambiental, capacitada a formular as diretrizes operacionais segundo as especificidades locais e regionais.

Os Centros de Educação Ambiental deverão ser estruturados de forma a propiciar condições de serem desenvolvidas as atividades necessárias ao planejamento adequado e ao acompanhamento da implantação e operação do programa, devendo servir de apoio logístico e técnico às entidades participantes.

\subsection{2 - Programa Agroflorestal}

A implantação do programa agroflorestal visará à produção de alimentos para a população local, junto com plantios florestais, utilizando-se métodos que reduzam o custo da atividade agrícola, e que não exijam a ocupação de um percentual de área superior ao que vem sendo ocupado ou que será ocupado com o plantio florestal. As alternativas de sistemas agroflorestais (associação de culturas, em áreas comuns ou contíguas, que têm por objetivo a produção agrossilvipastoril em regime sustentado) propostas são apresentadas no quadro 28.

O objetivo da implantação desse programa é gerar informações técnicas que permitam inserir no processo produtivo a população local, preparando a mesma para enfrentar o novo quadro econômico, cultural e social.

Quadro 28: Alternativas de Sistemas Agroflorestais

\begin{tabular}{|c|l|}
\hline \hline SISTEMA & \multicolumn{1}{c|}{ DESCRIÇÃO } \\
\hline \hline $\mathbf{1}$ & Árvores comerciais em associação temporária com cultivos de ciclo curto, denominado Taungya. \\
\hline $\mathbf{2}$ & Árvores comerciais entre cultivos permanentes de ciclo curto. \\
\hline $\mathbf{3}$ & Árvores comerciais entre cultivos permanentes de ciclo longo. \\
\hline $\mathbf{4}$ & Árvores comerciais em associação temporária com pastoreio. \\
\hline $\mathbf{5}$ & Árvores frutíferas em associação permanente com pastoreio ou cultivos. \\
\hline $\mathbf{6}$ & $\begin{array}{l}\text { Cultivos de ciclo longo em associação permanente com árvores multiuso (proteção, melhoramento do solo, } \\
\text { adubação verde, produção de lenha, entre outros). }\end{array}$ \\
\hline \hline
\end{tabular}

\subsection{3 - Enquadramento dos Programas de Fomento e Extensão Florestal na Convenção do Clima}

A partir da Conferência das Nações Unidas realizada no Brasil (ECO-92), diversas ações tem sido implementadas para minimizar as possíveis conseqüências das emissões dos gases do efeito estufa. Um dos exemplos é o Protocolo de Kyoto, de dezembro de 1997. O protocolo prevê, entre outras ações, a adoção de Mecanismo de Desenvolvimento Limpo, onde os países industrializados que se 
comprometeram a reduzir seus níveis de emissão podem adquirir, como forma de cumprir parte de seu compromisso de redução de emissão, Certificados de Redução de Emissão (CER) de gases de efeito estufa originados de projetos efetivamente implementados em países em desenvolvimento.

O Estado do Espírito Santo possui uma área de florestas plantadas de mais de 170 mil ha e tem buscado ampliar essa base florestal. O Estado também desenvolve projetos para o uso múltiplo da floresta (maior valor agregado pela diversificação da produção industrial) e, principalmente, tem primado ações voltadas ao fortalecimento da produção florestal cooperativa. Essas ações são consideradas como pontos fundamentais para a adequação de projetos voltados à geração de CERS.

Esses fatos aliados à vocação natural do Estado do Espírito Santo para a formação, condução e exploração florestal de projetos de reflorestamento, além de sua posição estratégica e infra-estrutura adequadas, colocam o Estado na vanguarda para a implantação de projetos de reflorestamento para esse fim e das possíveis negociações a serem realizadas para o seqüestro e fixação de carbono. Portanto, a possibilidade de enquadramento do Programa de Fomento como fonte de seqüestro e fixação de $\mathrm{CO}_{2}$, permitirá a captação de recursos internacionais, proporcionados pela Convenção do Clima, onde países emissores de $\mathrm{CO}_{2}$ poderão compensar a emissão com investimentos em projetos que promovam a captura do excedente de $\mathrm{CO}_{2}$ na atmosfera.

Para tanto, se torna necessário que o Estado inicie, através de uma ação coordenada com a iniciativa privada, envolvendo a Aracruz, principalmente no que se refere ao Programa de Fomento, estudos para a efetivação de projetos florestais que possam gerar os CERS, necessários à criação de uma carteira desses Certificados que poderão propiciar negócios com interessados em países industrializados. Esses CERS, que deverão ser referendados por organizações credenciadas internacionalmente, representam o volume de $\mathrm{CO}_{2}$ efetivamente fixado pelos projetos de plantios florestais e que, depois de adquiridos pelas empresas que emitem gases do efeito estufa, serão utilizados para cumprir suas metas de redução.

\section{2 - Recomendações de Uso Sustentável das Regiões Bioclimáticas (Aptidão, Potencialidades e Restrições)}

As recomendações de uso sustentável das regiões bioclimáticas são apresentadas no quadro 29. Essas recomendações foram desenvolvidas com base nas seguintes informações: aptidão das terras nas regiões bioclimáticas (obtidas com base no levantamento de campo realizado pela STCP) fornecidas pela Aracruz, características climáticas, biológicas, de solos e relevo definidas no diagnóstico e na avaliação das seguintes publicações: DADALTO (1992 e 1997) e BRASIL (1979).

\subsection{1 - Espécies Indicadas para as Diferentes Regiões Bioclimáticas do Estado para Plantios Florestais}

Foram definidas, como indicadas para utilização em plantios de produção ou proteção florestal nas regiões ou para plantios de comprovação da viabilidade de utilização, 12 (doze) espécies de Eucalyptus, 8 (oito) espécies de Pinus e 108 (cento e oito) espécies de Nativas (quadros 30 e 31).

\section{- Usos da Madeira e Extrativos das Espécies Indicadas}

Para as espécies de Eucalyptus spp. e Pinus spp. os usos classificados foram: Celulose; Painéis Reconstituídos (aglomerados, MDF e chapa dura de fibra); Compensados (laminação e faqueamento); Serraria (tábuas, caibros, ripas, vigas, etc.); Construções (currais, galpões, cercas, casas, entre outras); Móveis; Postes (iluminação e transmissão); Mourões; Dormentes; Resinagem (exclusivamente para o Pinus); e Carvão.

Em relação ao uso de espécies nativas locais e do País foram considerados os seguintes usos: Celulose; Painéis de Madeira (inclui os painéis reconstituídos e os laminados); Serraria; Móveis; Construção Civil (andaimes, cabos, formas, etc.); Mourões; Dormentes; Carvão; Essências; Medicinal; Alimento e Arborização Urbana. A grande maioria das espécies selecionada é de grande importância para a fauna, servindo de atrativo para pássaros e animais como abrigo e alimentação. 
Estudo ambiental para os programas de fomento...

Quadro 29: Recomendações de Uso Sustentável das Regiões Bioclimáticas

\begin{tabular}{|c|c|}
\hline $\begin{array}{c}\text { REGIÕES } \\
\text { BIOCLIMÁTICAS }\end{array}$ & APTIDÃO, POTENCIALIDADES E RESTRIÇÕES \\
\hline REGIÃO “1” & Inapta para a Agricultura. Indicada somente para a preservação da fauna e da flora. \\
\hline REGIÃO “2” & $\begin{array}{l}\text { Boa aptidão para o uso agropecuário, as partes altas podem ser utilizadas para plantios florestais. Inapta } \\
\text { para o cultivo do café. }\end{array}$ \\
\hline REGIÃO “3” & $\begin{array}{l}\text { De forma geral, a região possui aptidão não preferencial para a Silvicultura. Região Centro-Oeste com } \\
\text { aptidão exclusiva para silvicultura. Faixa litorânea indicada para preservação da fauna e flora. Porções } \\
\text { Central e Sul apresentam boa aptidão para pastagens plantadas e plantio de café conilon. A aptidão à } \\
\text { silvicultura é boa mas não preferencial. A porção sudoeste apresenta-se apta para o cultivo de café arábica } \\
\text { e inapta para culturas de ciclo curto. }\end{array}$ \\
\hline \multirow[b]{2}{*}{ REGIÃO “4” } & $\begin{array}{l}\text { Indicada preferencialmente para agropecuária, mas apresenta também aptidão para a silvicultura. Ao norte } \\
\text { a aptidão apresenta-se regular para lavouras de baixo e médio nível tecnológico. }\end{array}$ \\
\hline & $\begin{array}{l}\text { Porção Sul com manchas de boa aptidão agrícola em todos os níveis tecnológicos. A região Norte } \\
\text { apresenta restrições por estar sujeita a um regime irregular de chuvas e por possuir solos de baixa } \\
\text { fertilidade. }\end{array}$ \\
\hline REGIÃO “5” & $\begin{array}{l}\text { Boa aptidão para culturas de ciclo longo, especialmente pastagens plantadas. Faixa central de Norte a Sul } \\
\text { com aptidão exclusiva para silvicultura. Região susceptível a erosão e aptidão para culturas permanentes. } \\
\text { Porção nordeste exclusivamente apta para uso agropecuário apesar da aptidão para a Silvicultura. }\end{array}$ \\
\hline REGIÃO “6” & $\begin{array}{l}\text { Boa aptidão somente para cultura de ciclo longo e preferencial para a silvicultura ou preservação da } \\
\text { biodiversidade e recursos hídricos nos município de Ecoporanga, Água Doce do Norte, Pancas e Barra de } \\
\text { São Francisco. }\end{array}$ \\
\hline REGIÃO “7” & $\begin{array}{l}\text { Terras aptas para culturas de ciclo longo e inaptas para culturas de ciclo curto, sendo que a aptidão } \\
\text { preferencial é, em alguns casos, exclusiva para a silvicultura. Em regiões com declividade menor que } \\
30 \% \text {, recomenda-se o uso com lavouras de ciclo curto. }\end{array}$ \\
\hline REGIÃO “8” & $\begin{array}{l}\text { Boa aptidão para culturas de ciclo longo, porém a maior parte da região é indicada exclusivamente para a } \\
\text { silvicultura. }\end{array}$ \\
\hline REGIÃO “9” & Inapta para culturas de ciclo curto e longo, sendo indicada somente para a preservação da fauna e da flora. \\
\hline REGIÃO “10” & Indicada exclusivamente para a silvicultura. \\
\hline
\end{tabular}

Quadro 30: Espécies de Eucalyptus e Pinus Indicadas para Plantios

\begin{tabular}{|l|l|}
\hline \multicolumn{2}{|c|}{ ESPÉCIES EXÓTICAS } \\
\hline \multicolumn{2}{|c|}{ PINUS S } \\
\hline Eucalyptus alba & \\
Eycalyptus camaldulensis & \\
Eucalyptus citriodora & Pinus caribaea var. bahamensis \\
Eucalyptus cloeziana & Pinus caribaea var. caribaea \\
Eucalyptus grandis & Pinus caribaea var. hondurensis \\
Eucalyptus microcorys & Pinus elliottii var. densa \\
Eucalyptus pellita & Pinus elliottii var. elliottii \\
Eucalyptus pilularis & Pinus oocarpa \\
Eucalyptus saligna & Pinus patula \\
Eucalyptus tereticomis & Pinus taeda \\
Eucalyptus urophylla & \\
Hibridos (grandis + urophilla) & \\
\hline \hline
\end{tabular}


Quadro 31: Espécies de Nativas Indicadas para Plantios

\begin{tabular}{|c|c|c|c|}
\hline \multicolumn{4}{|c|}{ ESPÉCIES NATIVAS } \\
\hline \multicolumn{2}{|c|}{ NOME } & \multicolumn{2}{|c|}{ NOME } \\
\hline ESPECÍFICO & VULGAR & ESPECÍFICO & VULGAR \\
\hline Pouteria torta & Abiu & Clusia hilariana & Clusia \\
\hline Pachystroma Longifolium & Aça & Clusia nemorosa & Clusia \\
\hline Luehea divaricata & Açoita cavalo & Clusia spiritu-sanctensis & Clusia \\
\hline Astronium graveolens & Aderne & Trema micrantha & Curindiba \\
\hline Vochysia tucanorum & Angélica & Emmotom nitens & Faia \\
\hline Senna multijuga & Angico-branco & Pterygota brasiliensis & Farinha-seca \\
\hline Peltophorum dubium & Angico-canjiquinha & Senna australis & Fedegoso \\
\hline Anadenanthera peregrina & Angico-vermelho & Cassia ferruginea & Ferrugínea \\
\hline Psidum cattleianum & Araça & Campomanesia xanthocarpa & Gabiroba \\
\hline Centrolobium tomentosum & Arariba-rosa & Apuleia leiocarpa & Garapa \\
\hline Centrolobium robustum & Araribá-vermelho & Psidium guajava & Goiaba \\
\hline Schinus terebinthifolius & Aroeira & Symphonia globulifera & Guanandi \\
\hline Vernonia brasiliana & Assa-peixe & Phyllocarpus riedelli & Guaribú-sabão \\
\hline Diospyrus inconstans & Bacupari & Allagoptera arenaria & Guriri \\
\hline Rheedia calypytrata & Bacupari & Cecropia pachystachya & Imbaúba \\
\hline Schizolobium parahyba & Bandarra & Cecropia glaziovii & Imbaúba \\
\hline Pouteria guianensis & Bapeba & Didymopanax morototoni & Imbaubão \\
\hline Luehea grandiflora & Batinga & Couratari asterotricha & Imbirema \\
\hline Joannesia princeps & Boleira & Eriotheca macrophilla & Imbiruçu \\
\hline Hidrogaster trinerve & Bomba-d'água & Attalea burretiana & Indaiá \\
\hline Chamaecrista ensiformis & Brauna-parda & Inga flagelliformis & Ingá \\
\hline Melanoxylon brauna & Brauna-preta & Inga fagifolia & Ingá-mirim \\
\hline Moldenhawera floribunda & Caingá & Zeyhera tuberculosa & Ipê-felpudo \\
\hline Spondias purpurea & Cajá-mirim & Dalbergia nigra & Jacarandá-caviuna \\
\hline Anacardium occidentale & Cajueiro & Jacquinia brasiliensis & Jacquinia \\
\hline Gouchnatia polymorpha & Camará & Dialium guianensis & Jataí-preto \\
\hline Miconia albicans & Canela-de-velho & Hymenaea courbaril & Jatobá \\
\hline Jacaranda puberula & Caroba & Hymenaea rubriflora & Jatobá-mirim \\
\hline Cedrela odorata & Cedro & Conipa americana & Jenipapo \\
\hline Amburana cearensis & Cerejeira & Cariniana estrellensis & Jequitibá-branco \\
\hline Sparattosperma leucanthum & Cinco-folhas & Cariana legalils & Jequitijbá-rosa \\
\hline Pithecellobium pedicelare & Jueirana-branca & Caesalpinia ferrea & Pau-ferro \\
\hline Parkia pendula & Jueirana-vermelha & Piptadenia gonoacantha & Pau-jacaré \\
\hline Cordia trichotoma & Louro & Simarouba amara & Pau-paraíba \\
\hline Diplotropis incexis & Macanaíba-marreta & Tapirira guianensis & Pau-pombo \\
\hline Bowdichia virgilioides & Macanaiba-pele-de-sapo & Pterocarpus rohrii & Pau-sangue \\
\hline Jaracatia heptaphylla & Mamão-jaracatia & Cytharexyllum myrianthum & Pau-viola \\
\hline Zanthoxyllum rhoifolium & Mamica-de-porca & Terminalia kulhmannii & Pelada \\
\hline Lucuma buthyrocarpa & Mantegueira & Aspidosperma olivaceum & Pequiá \\
\hline Manilkara bella & Massaranduba & Aspidosperma pyrocollum & Pequiá \\
\hline Manilkara salzmannii & Massaranduba & Paratecoma peroba & Peroba-amarela \\
\hline
\end{tabular}


Quadro 31: Espécies de Nativas Indicadas para Plantios (Continuação)

\begin{tabular}{|l|c|l|c|}
\hline \multicolumn{2}{|c|}{ ESPÉCIES NATIVAS } \\
\hline \multicolumn{2}{|c|}{ NOME } & \multicolumn{1}{c|}{ NOME } \\
\hline ESPECÍFICO & VULGAR & \multicolumn{1}{c|}{ ESPEÍFICO } & VULGAR \\
\hline \hline Manilkara brasiliensis & Massaranduba-verdadeira & Aspidosperma cylindrocarpon & Peroba-osso \\
\hline Byrsonima sericea & Mucuri & Eugenia uniflora & Pitanga \\
\hline Couepia ruta & Oiti & Rheedia brasiliensis & Redia \\
\hline Clarisia racemosa & Oiticica & Mimosa bimucronata & Saco-de-mono \\
\hline Licania rigida & Oiticica & Swartia macrostachya & São-gonsalinho \\
\hline Chorisia speciosa & Paineira & Casearia sylvestris & Sapucaia \\
\hline Pseudobombax grandiflorum & Paineira-rosa & Lecythis lanceolata & Sapucaia-vermelha \\
\hline Polyandrococos caudenscens & Palmito-amargoso & Lecythis pisonis & Sapucainha \\
\hline Euterpe edulis & Palmito-doce & Carpotroche brasiliensis & Sibipiruna \\
\hline Attalea dubia & Palmito-naiá & Caesalpinia peltophoroides & Tento \\
\hline Manilkara longifolia & Parajú & Ormosia arborea & Vinhático \\
\hline Caesalpinia echinata & Pau-brasil & Plathymenia foliosa & \\
\hline Gallesia integrifolia & Pau-d'alho & & \\
\hline \hline
\end{tabular}

\section{4 - REFERÊNCIAS}

ADERES, AGÊNCIA DE DESENVOLVIMENTO EM REDE DO ESPÍRITO SANTO. Espírito Santo para Investidores. il. ADERES. Vitória - ES, 1998. 29 p.

ARACRUZ CELULOSE S. A.. Relatório Anual - 1998. Balanço Social e Ambiental. Aracruz, 1999.

ARACRUZ CELULOSE S. A.. Informações Básicas. (Folheto). Aracruz, 1998a.

ARACRUZ CELULOSE S. A. Relatório Anual - 1997. Balanço Social e Ambiental. Aracruz, 1998b.

ARACRUZ CELUlOSE S. A. Projeto Monitoramento de Microbacia. Relatório Anual das Atividades Realizadas em 1997. (Em Atendimento à Condicionante 3.8 da Licença de Operação 01/98 - IDAF). Aracruz, 1998c.

ARACRUZ CELULOSE S. A. Annual Report - 1996. Aracruz, 1997.

ARACRUZ CELULOSE S. A.. Projeto Monitoramento de Microbacia. Relatório Anual de Atividades - 1996. Aracruz, 1997.
ARACRUZ CELULOSE S. A. Relatório de Atividades Realizadas no Projeto de Monitoramento de Microbacia Durante o Ano de 1994. Aracruz, 1995.

ARACRUZ CELULOSE S. A. Documentação Referente à Ação Civil Contra o Fomento Florestal. v.2. Aracruz, 1994. 232p.

BERNARDES, A. T.; MACHADO, A.B.M. \& RYLANDS, A. B. Fauna Brasileira Ameaçada de Extinção. Fundação Biodiversitas para a Conservação da Diversidade Biológica. Belo Horizonte, 1990. 62p.

BOLEA, M.T.E. Evaluacion del Impacto Ambiental. Fundacion MAPFRE, Madri, 1984.

BORGES, A. J. M. \& VILLELA, T. M. C. Finanças dos Municípios capixabas - 1997. v.3. Aequus Consultoria. Vitória, 1997.

BRACELPA. Relatório Anual 1997. Associação Brasileira de Celulose e Papel BRACELPA. São Paulo, 1998.

BRACELPA. Relatório Estatístico de 1997 O Setor de Papel e Celulose. Associação Brasileira de Celulose e Papel - BRACELPA. São Paulo, 1998. 
BRASIL. Os Ecossistemas Brasileiros e os Principais Macrovetores de Desenvolvimento: Subsídios ao Planejamento da Gestão Ambiental. Ministério do Meio Ambiente, dos Recursos Hídricos e da Amazônia Legal. Secretaria de Coordenação dos Assuntos do Meio Ambiente. Programa Nacional do Meio Ambiente. Brasília, 1995. 108p.

BRASIL. Classes de Declividade das Terras do Estado do Espírito Santo. Aracruz, 1992b. 11p.

BRASIL. Aptidão Agrícola das Terras do Espírito Santo. il. Ministério da Agricultura, Secretaria Nacional de Planejamento Agrícola. BINAGRI. Brasília, 1979. 84p.

CAGED - Cadastro Geral de Empregados e Desempregados. Lei 4923 / 65. Endereço na Internet: http://www.mtb.gov.br/spes/caged/ esta/1998/est1098/. Outubro de 1998.

COSTA, C.C.C.; LIMA, J.P.; CARDOSO, L.D.; HENRIQUES, V.Q. Fauna do Cerrado: Lista Preliminar de Aves, Mamíferos e Répteis. IBGE. Rio de Janeiro, 1980. 224p.

COSTA, E. B.; LOSS, W. R. \& BARBOSA, C. A. Análise Comparativa da Competitividade Econômica do Eucalipto em Relação às Explorações Tradicionais de Café e Pecuária no Estado do Espírito Santo. Estudo de Caso do Programa de Fomento Florestal da Aracruz Celulose S.A. Vitória, 1998.

DADALTO, G. G. \& BARBOSA, C. A. Zoneamento Agroecológico para a Cultura do Café no Estado do Espírito Santo. il. SEAG-ES - Governo do Estado do Espírito Santo, Secretaria de Estado da Agricultura. Vitória, 1997. 28p.

DADALTO, G. G.; BARBOSA, C. A. \& SARTORI, M. Aptidão Florestal das Terras do Estado do Espírito Santo. Governo do Estado do Espírito Santo, Secretaria de Estado do Desenvolvimento Econômico, Fórum Sócio-Econômico do Espírito Santo, Grupo de Trabalho da Indústria Florestal. Vitória, 1992. $16 \mathrm{p}$.

EMCAPA, EMPRESA CAPIXABA DE PESQUISA AGROPECUÁRIA. Carta Agroclimática do Estado do Espírito Santo. EMCAPA. Vitória, 1986.
ESPÍRITO SANTO. Anuário Estatístico do Estado do Espírito Santo - 1995. v.25. Governo do Estado do Espírito Santo, Secretaria de Estado de Ações Estratégicas e Planejamento. IJSN (Instituto de Apoio à Pesquisa e ao Desenvolvimento "Jones Alves dos Santos”). Vitória, 1998. 254p.

ESPÍRITO SANTO. Decreto Estadual $\mathbf{N}^{\mathbf{0}}$ 4.124 de 12 de junho de 1997. Diário Oficial do Estado do Espírito Santo. Vitória, 1997a.

ESPÍRITO SANTO. Lei Estadual No $\mathbf{N}^{0} \mathbf{5 5 4}$. 30 de Dezembro de 1997. Diário Oficial do Estado do Espírito Santo. Vitória, 1997b.

ESPÍRITO SANTO. Decreto Estadual $\mathbf{N}^{\circ}$ 4.157-N de 25 de agosto de 1997. Diário Oficial do Estado do Espírito Santo. Vitória, $1997 \mathrm{c}$.

ESPÍRITO SANTO. Decreto Estadual No 163 26 de Agosto de 1997. Seção 1.. Diário Oficial do Estado do Espírito Santo. Vitória, 1997d.

ESPÍRITO SANTO. $\mathbf{1}^{\mathbf{0}}$ Seminário sobre Recursos Florestais do Espírito Santo Setor Florestal do Espírito Santo: Diagnóstico Documento Síntese. SEAG/ES Governo do Estado do Espírito Santo, Secretaria de Estado da Agricultura BANDES - Banco de Desenvolvimento do Espírito Santo S.A. Vitória, 1988.

GAZETA MERCANTIL. Balanço Anual 1997: Espírito Santo. Ano II, No 2 . Rio de Janeiro, agosto de 1997.

GRIGATO, R. B. \& MORROT. S. Programa de Fomento Florestal - Cenários Municipais. Aracruz, 1991.

IBAMA. Portaria $\mathbf{n}^{\mathbf{0}}$ 062, de 17 de junho de 1997. IBAMA. Brasília, 1997.

IBAMA. Censo Demográfico de 1991Dimensões das Carências. Unidades de Conservação no Brasil - Cadastramento e Vegetação (1991-1994). IBAMA. Brasília, 1995. 225p.

IBAMA. Portaria $\mathbf{n}^{\mathbf{0}} \mathbf{4 5}-\mathrm{N}$, de 27 de abril de 1992. IBAMA. Brasília, 1992. 
IBAMA， INSTITUTO BRASILEIRO DE MEIO AMBIENTE E RECURSOS NATURAIS RENOVÁVEIS. Projeto Quelônios da Amazônia - 10 anos. IBAMA XVI. iI. Brasília, 1989. 119p.

IBAMA. Portaria $\mathrm{n}^{0}$ 1.522, de 19 de dezembro de 1989. IBAMA. Brasília, 1989.

IBDF/UFRRJ. Análise do Setor Industrial Florestal Espírito Santo. il. IBDF / UFRRJ. Rio de Janeiro, 1984.

IBDF, INSTITUTO BRASILEIRO DE DESENVOLVIMENTO FLORESTAL. A Política do Reflorestamento no Espírito Santo. IBDF. Vitória, 1982.

IBDF. Plano de Manejo do Parque Nacional de Caparaó. Ministério da Agricultura. IBDF Fundação Brasileira para a Conservação da Natureza. Brasília, 1981.

IBDF/FBCN. Encontros Regionais sobre Conservação da Fauna e Recursos Faunísticos (1976-1977). IBDF. Brasília, 1980. 374p.

IBGE. Censo Agropecuário 1995-1996 Espírito Santo. IBGE. Rio de Janeiro, 1998. $211 \mathrm{p}$.

IBGE. Produção da Extração Vegetal e da Silvicultura - 1995. v.10. IBGE, Departamento de Agropecuária. Rio de Janeiro, 1998. 277p.

IBGE. Folha SE.24 Rio Doce. v.34. il., 6 mapas. IBGE. Rio de Janeiro, 1997. 548p.

IBGE. Anuário Estatístico do Brasil - 1996. v.56. IBGE. Rio de Janeiro, 1996a.

IBGE. Contagem da População 1996. (CDROM). IBGE. Rio de Janeiro, 1996b.

IBGE. Produção da Extração Vegetal e da Silvicultura - 1992. v.7. IBGE, Departamento de Agropecuária. Rio de Janeiro, 1992. 249p.

IBGE. Censo Demográfico de 1991 Dimensões das Carências Sociais: Informações Municipais - Espírito Santo. v.8, IBGE. Rio de Janeiro, 1991. 58p.

IBGE. Censo Agropecuário de 1985 Espírito Santo. IBGE. Rio de Janeiro, 1990. 370p.
IBGE. Censo Agropecuário de 1975 Espírito Santo. IBGE. Rio de Janeiro, 1979.

IBGE, INSTITUTO BRASILEIRO DE GEOGRAFIA E ESTATÍSTICA. Geografia do Brasil - Região Sudeste. v.3., il. IBGE. Diretoria Técnica. SERGRAF. Rio de Janeiro, 1977. 667p.

KISE, C. M. Análise da Situação da Indústria Madeireira no Estado do Espírito Santo. Tese de Mestrado. Universidade Federal de Viçosa. Viçosa, 1984.

RADAMBRASIL, PROJETO. Folhas SF.23/24: Rio de Janeiro/Vitória. v.32. 6 mapas. Rio de Janeiro, 1983. 780p.

SALVADOR, A. A. Proposta de Plano Estadual de Desenvolvimento Florestal. Governo do Estado do Espírito Santo, Secretaria de Estado do Desenvolvimento Econômico, Fórum Sócio-Econômico do Espírito Santo, Grupo de Trabalho da Indústria Florestal. Vitória, 1992. 47p.

VENTURINI, A. N. et al. Aves e Mamíferos na Restinga: Parque Estadual Paulo César Vinha Setiba - Guarapari/ES. v.1. il. SEDESU - Secretaria de Estado de Desenvolvimento Sustentável - Vitória, 1996. $168 \mathrm{p}$. 